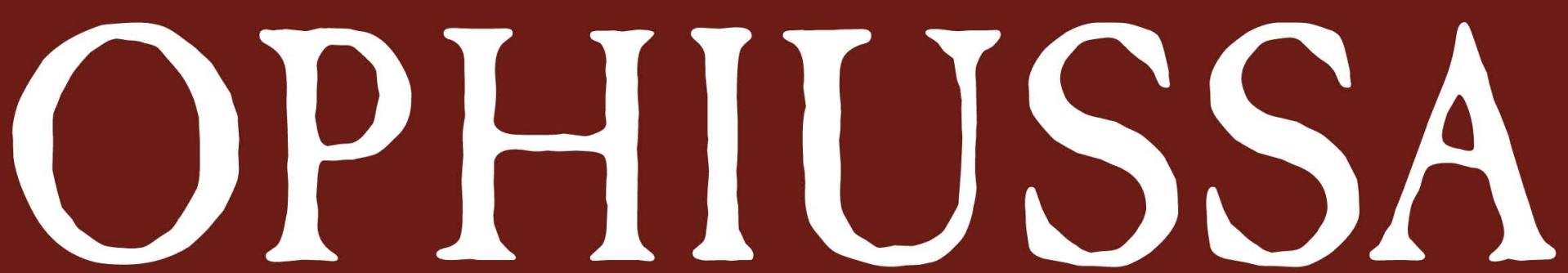

REVISTA DO CENTRO DE ARQUEOLOGIA DA UNIVERSIDADE DE LISBOA

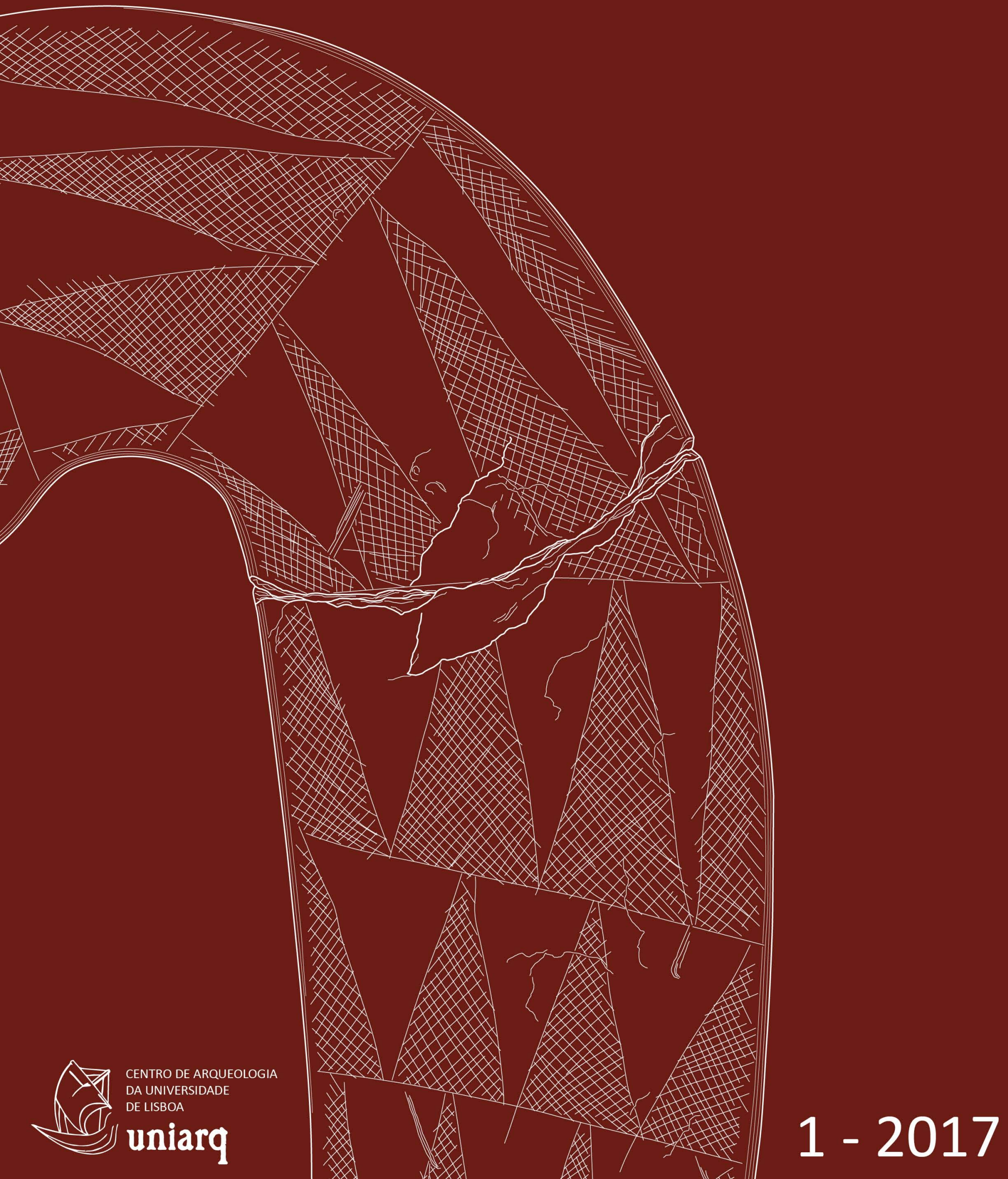


OPHIUSSA. Revista do Centro de Arqueologia da Universidade de Lisboa

ISSN $1645-653 X$

Publicação anual

Volume 1 - 2017

Direcção e Coordenação Editorial:

Ana Catarina Sousa

Elisa Sousa

Rui Boaventura

Conselho Científico:

André Teixeira (Universidade Nova de Lisboa)

Carlos Fabião (Universidade de Lisboa)

Catarina Viegas (Universidade de Lisboa)

Gloria Mora (Universidad Autónoma de Madrid)

Grégor Marchand (Centre National de la Recherche Scientifique)

João Pedro Bernardes (Universidade do Algarve)

José Remesal (Universidade de Barcelona)

Leonor Rocha (Universidade de Évora)

Manuela Martins (Universidade do Minho)

Maria Barroso Gonçalves (Instituto Superior de Ciências do Trabalho e da Empresa)

Mariana Diniz (Universidade de Lisboa)

Raquel Vilaça (Universidade de Coimbra)

Xavier Terradas Battle (Consejo Superior de Investigaciones Científicas)

Secretariado: André Pereira

Capa: André Pereira sobre Báculo do Sobral do Martim Afonso (desenho de Marco Andrade).

Paginação: Elisa Sousa

Impressão: Europress

Data de impressão: Novembro de 2017

Edição impressa (preto e branco)

200 exemplares

Edição digital (a cores)

www.ophiussa.letras.ulisboa.pt

ISSN: $1645-653 X$

Depósito legal: 190404/03

Copyright $\odot 2017$, os autores

Edição:

UNIARQ - Centro de Arqueologia da Universidade de Lisboa

Faculdade de Letras de Lisboa

1600-214 - Lisboa

www.uniarq.net - www.ophiussa.letras.ulisboa.pt - uniarq@letras.ulisboa.pt

O cumprimento do acordo ortográfico de 1990 foi opção de cada autor. 


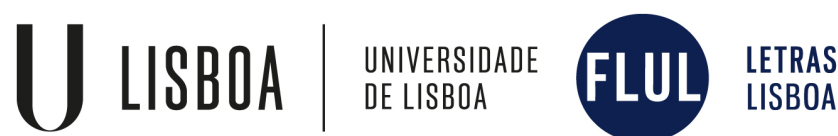

\section{O SÍTIO PRÉ-HISTÓRICO DO SOBRAL DO MARTIM AFONSO (SALVATERRA DE MAGOS, PORTUGAL): UM CURIOSO CONTEXTO DO NEOLÍTICO FINAL/CALCOLÍTICO NA MARGEM ESQUERDA DO BAIXO TEJO}

MARCO ANTÓNIO ANDRADE*

\section{RESUMO}

Conhecido desde finais do século XIX e assumido como um lugar de enterramento devido à recolha de alguns artefactos e objectos característicos deste tipo de contextos, o sítio pré-histórico do Sobral do Martim Afonso oferece uma série de questões pertinentes ao estudo das comunidades do Neolítico final/Calcolítico do Sudoeste peninsular. Destaca-se: 1) a aparente coincidência entre um lugar habitacional e um lugar de enterramento, reunindo-se num mesmo local espaços dos vivos e espaços dos mortos; 2) o carácter «culturalmente megalítico» do contexto funerário aí identificado, numa área onde não se conhecem antas nem onde, devido à inexistência efectiva de suportes construtivos adequados no substrato geológico local, estas poderiam ter virtualmente existido; 3 ) a sua posição geográfica, em área de charneira entre o Alentejo e a Península de Lisboa. Este trabalho pretende assim apresentar novas leituras interpretativas; à luz dos dados recentes, sobre este sítio arqueológico, a respeito da sua possível funcionalidade específica e de acordo com os dados actualmente disponíveis.

Palavras-chave: Baixo Tejo; Neolítico final - Calcolítico; Contextos funerários; Contextos habitacionais.

\section{ABSTRACT}

Known since the late 19th century and assumed as a burial place due to the finding of some artefacts and objects typical of that kind of contexts, the prehistoric site of Sobral do Martim Afonso offers a series of questions regarding the study of the Late Neolithic/Chalcolithic communities in the Southwestern Iberian Peninsula. One can highlight: 1) the apparent coincidence between a settlement and a burial site, gathering in the same place the spaces for the living and the spaces for the dead; 2 ) the «culturally megalithic» features of the funerary context thereby identified, in an area in which there are no known megalithic monuments and where they could not have virtually existed, due to the actual absence of capable constructive supports in the local geological substract; 3) its geographical position, in the transition area between Alentejo and the Lisbon Peninsula. This paper intends to present new interpretative readings about this archaeological site, regarding its possible specific functionality and according to the data currently available.

Keywords: Lower Tagus; Late Neolithic-Chalcolithic; Funerary contexts; Habitational contexts. 
Para o meu Martim, que não é também Afonso apenas por relutância da Mãe...

\section{ABRINDO...}

O sítio do Sobral do Martim Afonso é essencialmente conhecido como um espaço de aparente carácter funerário desde o último quartel do século XIX, a partir dos textos de A. F. Simões sobre a Introdução à Archeologia da Península Ibérica, onde se refere a "Sepultura de Martim Affonso, perto Muge» como o local de proveniência de uma alabarda de sílex, lâminas de sílex e um báculo de xisto gravado então conservados no Museu da Escola Politécnica (Simões 1878: 42, 53-54; cf. também Cardoso 2016), resultado de uma intervenção de F. Pereira da Costa talvez realizada durante os seus trabalhos nos concheiros de Muge em 1863, em colaboração com Carlos Ribeiro.

Existe contudo uma curiosa passagem de C. Ribeiro, durante a descrição do báculo recolhido na anta da Estria, referindo o seguinte (Ribeiro 1878: 9): "O sr. Filippe Simões, na sua introdução à Archeologia da Península lbérica, apresenta o desenho de outro objecto muito semelhante a este, que diz existir no Museo da Escola Polytecnica, e denomina-o "baculo", o qual diz ter sido encontrado na sepultura de Martim Affonso, mas de cujo achado não nos recordamos, posto termos sido nós quem primeiro explorámos esta sepultura, quando nos occupavamos de semelhantes investigações na freguezia de Mugem». Contudo, A. F. Simões esclareceu está questão pessoalmente com $\mathrm{F}$. Pereira da Costa (como se verá adiante), assegurando a proveniência do báculo como da sepultura de Martim Afonso.

Também S. Ph. Estácio da Veiga, fazendo a súmula das placas de xisto gravadas em território português de modo a contextualizar os exemplares por si recolhidos em Aljezur, se refere ao báculo proveniente da «sepultura de Martim Affonso» (Veiga 1887: 431, 436-438, 440, 450), ilustrando-a em mapa realizado em 1884 com a distribuição das placas de xisto gravadas conhecidas à altura em Portugal (cf. também Gonçalves 2004). Da mesma maneira, M. E. Cartailhac menciona o báculo de Martim Afonso, como um de três exemplos de artefactos deste tipo conhecidos à altura em território português (Cartailhac 1886: 93-94, 96).

Sobre a presença deste espólio nas reservas do Museu Nacional de Arqueologia, é apenas referido por E. A. Correia Lopes a entrada, em Dezembro de
1912, de uma «placa de lousa, de forma encurvada, preistórica, encontrada em uma sepultura de Martim Afonso (talvez das escavações de Pereira da Costa)», transferida do Museu da Escola Politécnica e sem fazer qualquer menção aos restantes componentes do conjunto (Lopes 1913: 165).

Posteriormente, é referido por G. e V. Leisner nos seus Megalithgräber (estando mencionados apenas a alabarda e o báculo), sendo descrito da seguinte forma (traduzido por alto do original alemão divulgado em Leisner - Leisner 1959: 275):

\section{Grupo 5}

Sepultura de Martins Affonso, Estampa 44, Monumento 12

Localização: em Muge

Esta sepultura, cuja forma é desconhecida, pode ser uma Anta de acordo com o inventário; alguns artefactos notáveis foram recuperados há alguns anos, conservados no Museu Etnológico com os números 7142 e 7154.

Ponta de punhal larga, triangular, de base ligeiramente cónica, polida a meio de ambas faces e retocada nos bordos, sílex castanho-escuro (1); báculo, decorado com bandas transversais de «dentes de lobo» (2).

Apesar de os artefactos aqui recolhidos se tratarem de peças comummente integráveis, a nível crono-cultural, em conjuntos megalíticos ratificados, estranha-se a posição aparentemente absurda deste contexto fora do âmbito geográfico de qualquer grupo megalítico conhecido, tendo apenas como paralelo uma outra curiosa ocorrência, a de Monte da Barca (Coruche) - para além do misterioso caso de Vale de Cavalos (Chamusca).

No âmbito da minha participação, em colaboração com César Neves e Gonçalo Lopes, no encontro Muge 150th: Conference on the 150th Anniversary of the Discovery of the Mesolithic Shellmiddens at Muge (realizado em Salvaterra de Magos em Março de 2013) com a contribuição «Beyond the Mesolithic shell-middens: a chronocartographic overview of the ancient peasant communities in Muge», foi analisado um conjunto de materiais arqueológicos recolhidos em inícios da década de 90 do século passado na área de Muge, entre os quais figuravam alguns provenientes do Sobral do Martim Afonso. Contudo, os elementos referentes a este sítio não se enquadravam naquilo que se poderá definir estritamente como contexto funerário, apresentando-se eminentemente como materiais provenientes de um contexto habitacional. 
Desta maneira, ainda mais curioso se tornou este contexto, que aparentava reunir espaços dos vivos e espaços dos mortos num mesmo local.

Julgando que a referência feita a este sítio no artigo dos Proceedings do encontro acima referido seria demasiado curta para a sua importância relativa, relegou-se para outro contexto a sua apresentação individual - sendo os resultados aqui divulgados.

Agradece-se ao Dr. António Carvalho a autorização para estudo do espólio do Sobral do Martim Afonso pertencente ao acervo do Museu Nacional de Arqueologia (assim como se agradece a presteza de Luísa Guerreiro, Paulo Alves e Luís Antunes, neste e noutros projectos). Agradece-se ainda a Gonçalo Lopes a cedência dos materiais por si recolhidos (e ainda as fotografias de enquadramento do sítio aqui apresentadas, em altura de maior caudal do Paul do Concelho, simulando o paleo-estuário), a Bruno Magalhães pelo apoio na classificação possível do espólio osteológico humano, e à Casa Cadaval (na pessoa do Eng. ${ }^{\circ}$ António Saldanha) a autorização para o acesso ao sítio.

\section{LOCALIZAÇÃO E CARACTERIZAÇÃO}

O sítio pré-histórico do Sobral do Martim Afonso localiza-se administrativamente na freguesia de Muge, concelho de Salvaterra de Magos, distrito de Santarém. Posiciona-se, segundo a folha n ${ }^{\circ} 378$ da Carta Militar de Portugal (esc. 1:25000), nas seguintes coordenadas UTM (datum ED1950):

$$
\begin{aligned}
& X(m): 0527250 \\
& Y(p): 4327450 \\
& N(\text { alt.): } 14 \mathrm{~m}
\end{aligned}
$$

Ou, em coordenadas geográficas (datum WGS84):

\section{Lat. (N): 39॰05'37,83"}

Long. (W): $08^{\circ} 41^{\prime} 10,65^{\prime \prime}$

Localiza-se sobre os níveis dos terraços inferiores do Plistocénico (T3), encaixados entre a escarpa de calcários miocénicos de fácies lacustre da margem direita do Tejo e os depósitos pliocénicos acima dos limites do Miocénico detrítico da margem esquerda (nível geo-morfológico de MoraLamarosa). Inclui-se numa paisagem aberta genérica, caracterizada como uma área de encosta suave que desce desde a Serra de Almeirim até à margem do Tejo, configurando uma vasta área aplanada

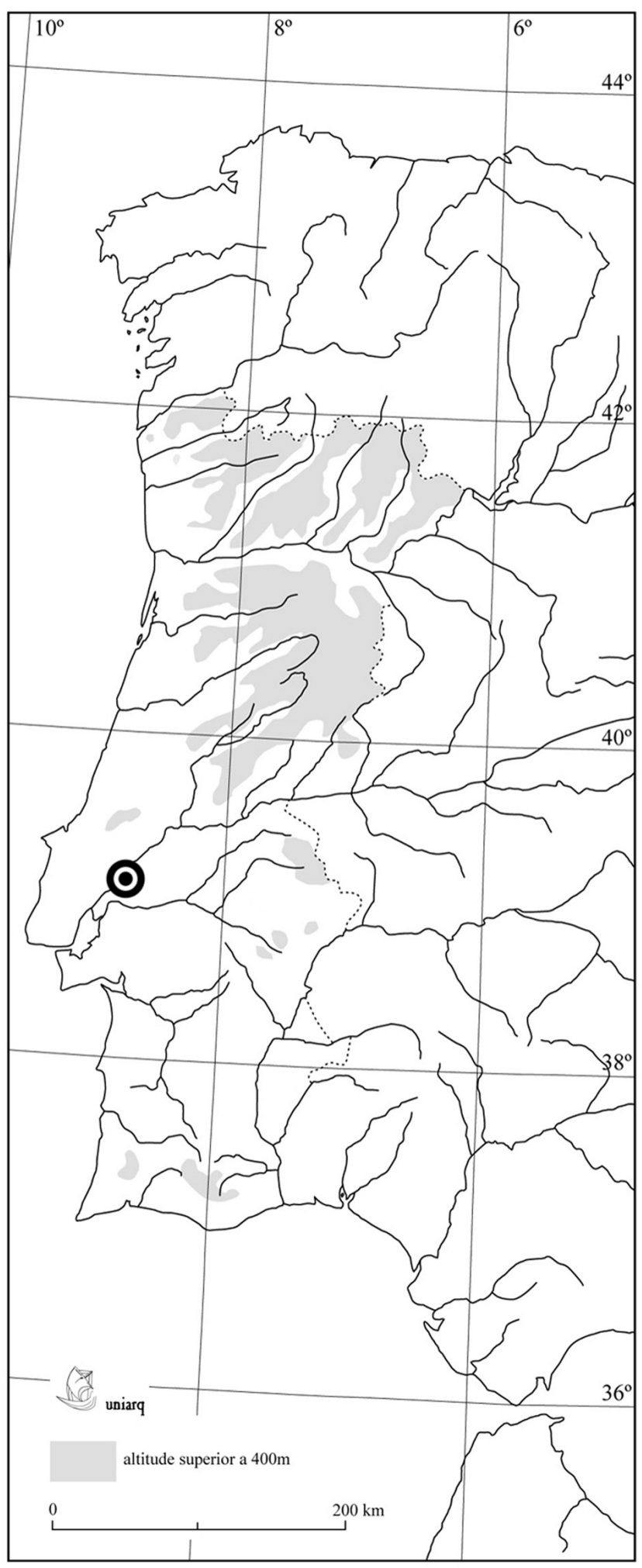

Fig. 1 - Localização do sítio pré-histórico do Sobral do Martim Afonso no Ocidente peninsular.

correspondente aos terraços de depósitos fluviais (Daveau 1980; Martins 2004; Azevêdo 2004; Freitas et al. 2006).

Este é genericamente um espaço definido 


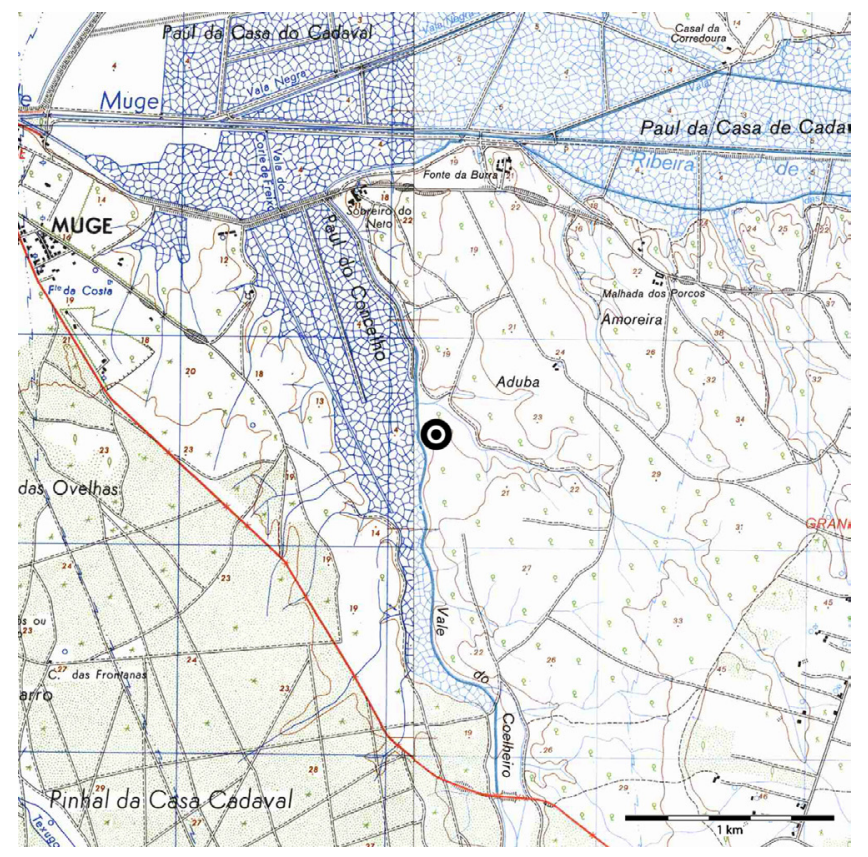

Fig. 2 - Localização do sítio pré-histórico do Sobral do Martim Afonso na folha n 378 da Carta Militar de Portugal (esc. 1:25000).

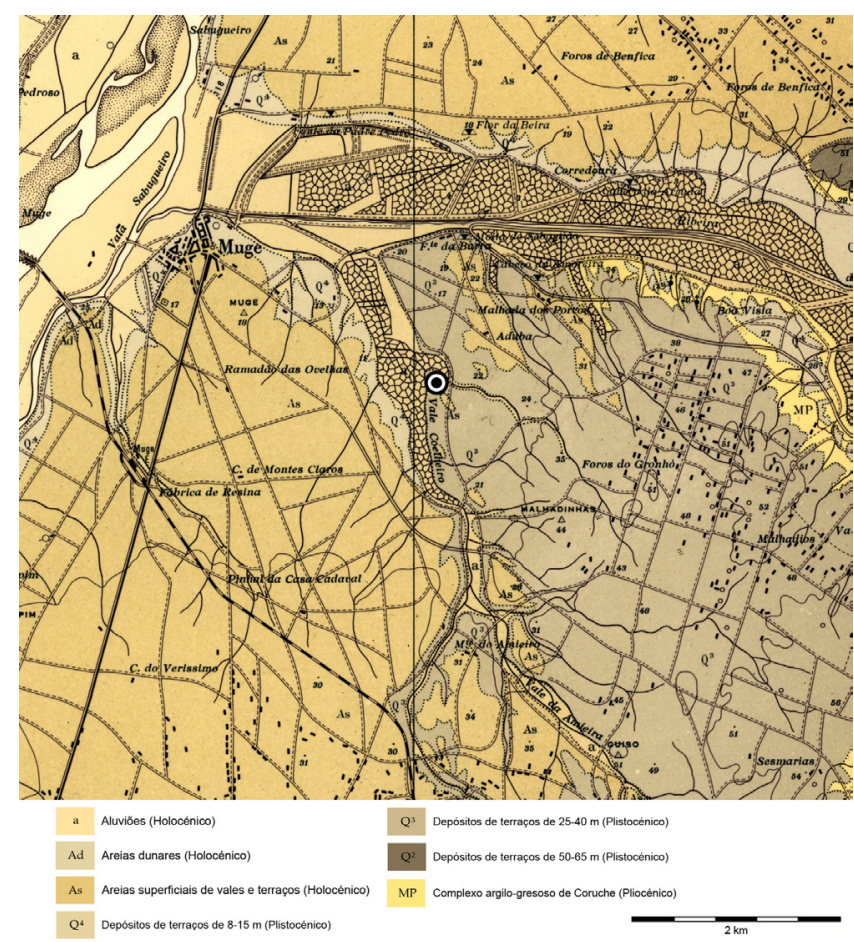

Fig. 3 - Localização do sítio pré-histórico do Sobral do Martim Afonso na folha n $31 \mathrm{C}$ da Carta Geológica de Portugal (esc. 1:50000).

pelo paleo-estuário formado pela transgressão flandriana, preenchendo o entalhe würmiano do Tejo e subsidiários directos, atingindo o seu máximo em \pm 5000 BP. Assim, em relação ao paleo-ambiente em que se incluiria, este caracteriza-se, a partir de datas que coincidem sensivelmente com a instalação das primeiras comunidades camponesas do Neolítico antigo, pelo desenvolvimento de planícies mareais e marismas salobres, com a frente deltaica estabelecida em posição fronteira a Muge; por alturas do final do Calcolítico, esta área caracteriza-se já pela presença de barras e canais mareais e várzeas/planícies de inundação fluvial, subsistindo ainda as planícies de maré na zona abaixo de Muge, fronteira à foz da Ribeira de Magos (Vis et al. 2008; Vis et al. 2010; van der Schriek et al. 2007, 2008; Freitas et al. 2013).

Um ambiente florestal húmido, dominado por pinus, caracteriza esta área durante o Mesolítico final, sendo substituído por paisagens abertas de quercus por volta do advento das primeiras comunidades neolíticas, reflectindo uma certa inflexão ambiental (tendência de secagem regional). A partir do Calcolítico, sendo o regime de maré progressivamente substituído pelo regime fluvial de água doce, regista-se uma importante perturbação na vegetação atribuível possivelmente a actividade humana (van der Schriek et al. 2008: 148).

O sítio implanta-se, neste contexto, sobre um pequeno esporão sobranceiro à Ribeira do Vale do Coelheiro (afluente da margem esquerda da Ribeira de Muge), na confluência desta com um curso de água de menores dimensões e em posição fronteira ao Paul do Concelho, a cotas baixas, numa paisagem genericamente aberta que não oferece grandes constrições visuais - não havendo aparentes preocupações de carácter defensivo na escolha da sua implantação.

Encontra-se assim num ambiente ecotónico, entre o interior e a área paleo-estuarina do Tejo. Este paleo-estuário, anterior à sedimentação e formação das planícies aluviais holocénicas (e com as características apontadas acima), providenciaria uma importante disponibilidade de recursos possivelmente complementada com a exploração sazonal do interior. Encontra-se incluído numa mancha de ocupação horizontal que se estende até à Ribeira de Muge, compreendendo igualmente os sítios de Adua 1 e Sobreiro do Neto (ambos distanciando-se cerca de $800 \mathrm{~m}$ de Sobral do Martim Afonso, no mesmo plano topográfico).

O sítio encontra-se referenciado na base de dados Endovélico (da responsabilidade da DGPC) com o CNS 6681, sendo aqui estranhamente descrito como um «sítio onde foi recolhido um molde de amuleto em xisto, ornamentado com triângulos incisos», conservado no British Museum - sendo que 


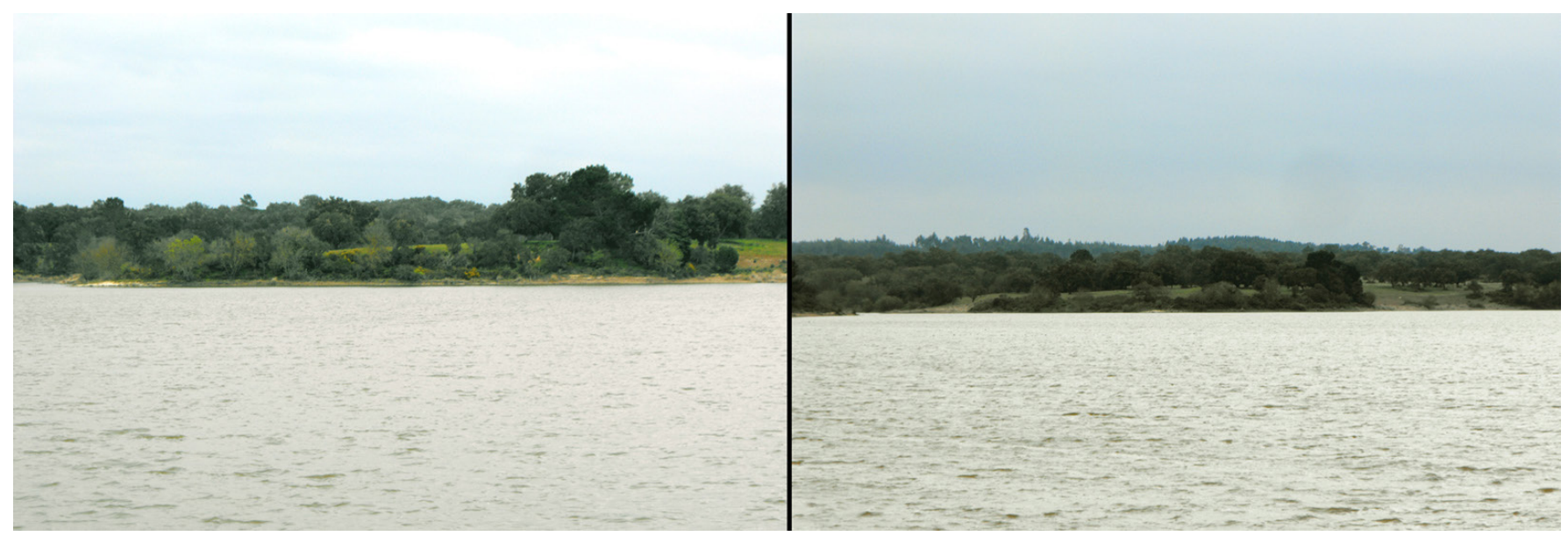

Fig. 4 - Aspecto do sítio do Sobral do Martim Afonso, visto da margem oposta da Ribeira do Vale do Coelheiro (actualmente represada); em primeiro plano, o Paul do Concelho em altura de maior caudal, simulando o paleo-estuário. Fotografias de Gonçalo Lopes.

o único espólio referido, entendido como «achado isolado» é o tal «molde de amuleto em xisto»!...

Contudo, este elemento refere-se somente a uma réplica do báculo recolhido no Sobral do Martim Afonso, réplica esta pertencente ao acervo do British Museum e referida por V. Correia aquando da recensão crítica do livro Progressive Portugal de Ethel C. Hargrove, publicado em 1914. Traduzindo directamente do original inglês, V. Correia refere: «No Museu Britânico, armario K, da secção de preistória, podem ver-se o molde de um amuleto de xisto, ornado com triângulos riscados, do período neolítico, de Martim Afonso, perto de Muge e Santarém» (Correia 1915: 298). Mais adiante, faz a clara distinção entre «os objectos arqueológicos, verdadeiros ou moldados, que o Museu Britânico possui do nosso país» (Correia 1915: 299), percebendo-se assim que molde (no sentido de algo que é moldado) se refere apenas a uma réplica de um artefacto (neste caso, do báculo) e não de um artefacto per se.

Existe ainda, na mesma base de dados, uma outra entrada para "Sobral do Martim Afonso» (CNS 11567), referindo-se contudo aos vestígios paleolíticos identificados na década de 40 do século passado durante os trabalhos do Instituto de Antropologia da Universidade do Porto e da Comissão dos Serviços Geológicos de Portugal na área de Muge - que poderá igualmente ser a área de proveniência dos bifaces e machados de mão que se encontram no Museu Nacional de Arqueologia com a referência «Martim Afonso, Muge» (Varanda Andrade no prelo).

O espólio aqui estudado reparte-se em dois conjuntos: o primeiro refere-se aos materiais provenientes do contexto funerário, pertencentes ao acervo do Museu Nacional de Arqueologia; o segundo refere-se aos materiais provenientes do contexto habitacional, recolhidos por Gonçalo Lopes em inícios da década de 90 do século passado (durante a execução da sua tese de Licenciatura em História e Património pela Universidade de Évora) e cedidos para estudo no âmbito da investigação sobre a evolução das antigas comunidades camponesas desde o Neolítico antigo até ao Calcolítico final na área de Muge (Andrade et al. 2015).

\section{O CONTEXTO FUNERÁRIO}

Actualmente, não se conhece o carácter estrutural exacto deste contexto funerário, sendo apenas referido que se trataria de um «depósito mortuário denominado sepultura, no sítio de Martim Affonso em Mugem, a curta distância do Cabeço da Arruda» (Veiga 1887: 439). Com efeito, o contexto geológico em que este sítio se inclui (depósitos quaternários) permite refutar a hipótese de se tratar de um efectivo monumento megalítico (no sentido estrito do termo). Da mesma maneira, os contextos geológicos limítrofes (nomeadamente, calcários miocénicos), que poderiam ter sido usados como áreas de aquisição, não permitem a obtenção de suportes passíveis de serem utilizados como ortóstatos.

A. F. Simões, recolhendo informação directamente junto do escavador deste contexto, transcreve literalmente a sua descrição, cedida em espístola (Simões 1878: 101): "A sepultura de Martim Affonso não é, como á primeira vista parece, de sujeito 

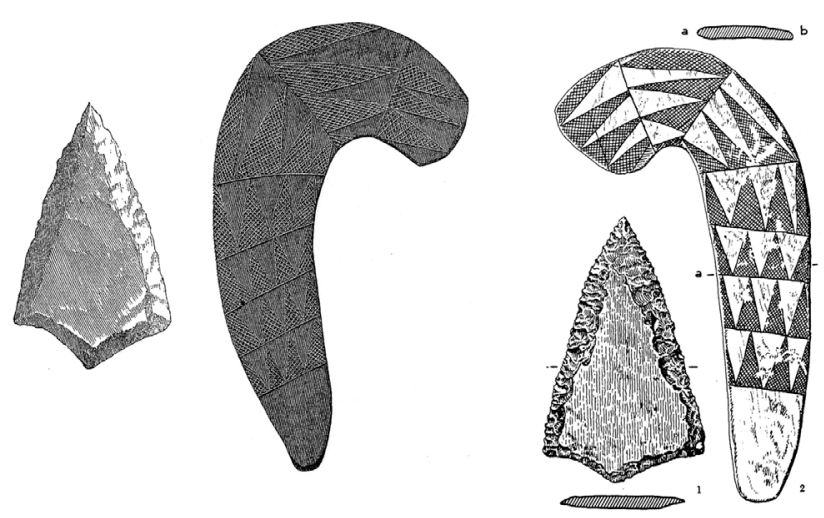

Fig. 5 - O espólio da «sepultura» de Martim Afonso, à esquerda segundo A. F. Simões (1878: 42 - fig. 15, 53 - fig. 33; adaptado) e à direita segundo G. e V. Leisner (1959: Taf. 44; adaptado). De notar, no desenho publicado por A. F. Simões, para além da reprodução espelhada dos artefactos, o erro da representação da primeira banda de triângulos do báculo.

assim chamado, mas um sitio que é conhecido por este nome, na propriedade do duque de Cadaval (residente em Paris). Esta sepultura era de tres lages compridas e duas estreitas nas extremidades, e tinha um capeamento de lages pequenas. Dentro continha ossos de um esqueleto, dos quaes só se aproveitaram alguns fragmentos de ossos longos, e o mais que V. viu no Museu. Esta propriedade do duque é nas margens da ribeira de Muge, e perto do Cabeço da Arruda, que também pertence ao mesmo duque», referindo ainda o báculo, as lâminas de sílex, a alabarda e os recipientes cerâmicos de pequena dimensão.

Como se denota pela descrição, não se trata propriamente de uma anta (e F. Pereira da Costa conhecia-as bem), percebendo-se contudo que se trataria de algo estruturado, talvez de tendência cistóide. Assim, este sítio poderá configurar algo semelhante ao registado em Monte da Barca, correspondendo a inumações realizadas possivelmente em «fossa» em contextos geológicos brandos (cf. Vicente et al. 1971; Gonçalves 2011), todavia distinguindo-se por apresentar alguma estruturação ou delimitação do espaço sepulcral.

O espólio daqui proveniente encontra-se representado pelas seguintes categorias: Recipientes cerâmicos, Artefactos de pedra lascada, Artefactos relacionados com o Sagrado e Espólio osteológico. Foram utilizados para o seu estudo, adaptados à realidade em análise, os critérios descritivos actualmente em uso pelo Grupo de Trabalho sobre as Antigas Sociedades Camponesas da UNIARQ (e expressos, por exemplo, em Andrade 2009; Gonçalves 1989a, 2003, 2004, 2011, 2013; Sousa 2010).

\section{Recipientes cerâmicos}

Quatro elementos se contam nesta categoria, estando referenciados com os números de inventário MNA 997.73.1 a 4 - referindo-se a duas pequenas taças em calote aberta, uma taça alta fechada e um fragmento de bojo de recipiente cerâmico. Descrevem-se da seguinte forma:

\section{MNA 997.73.1}

Pequena taça em calote aberta, apresentando $5,5 \mathrm{~cm}$ de diâmetro externo, $4,7 \mathrm{~cm}$ de diâmetro interno e $5,2 \mathrm{~cm}$ de diâmetro do bojo. Regista $3 \mathrm{~cm}$ de altura e $2,2 \mathrm{~cm}$ de profundidade, tendo $0,5 \mathrm{~cm}$ de largura do lábio, $0,6 \mathrm{~cm}$ de espessura do bojo e $0,8 \mathrm{~cm}$ de espessura do fundo. Apresenta cozedura oxidante com arrefecimento redutor, com pasta semi-compacta com abundantes elementos não plásticos de fino calibre (quartzos angulosos e subrolados, feldspatos, escassas moscovites), sendo as suas superfícies alisadas.

Número de inventário antigo: MNA 3:851 (número vermelho).

\section{MNA 997.73 .2}

Taça alta fechada, apresentando $7,8 \mathrm{~cm}$ de diâmetro externo, $6,7 \mathrm{~cm}$ de diâmetro interno e 8,5 $\mathrm{cm}$ de diâmetro do bojo. Regista $5,8 \mathrm{~cm}$ de altura e $4,6 \mathrm{~cm}$ de profundidade, tendo $0,7 \mathrm{~cm}$ de largura do lábio, $0,9 \mathrm{~cm}$ de espessura do bojo e $1 \mathrm{~cm}$ de espessura do fundo. Apresenta cozedura e arrefecimento redutores, com pasta semi-compacta com escassos elementos não plásticos de fino calibre (quartzos angulosos e sub-rolados, feldspatos), sendo as suas superfícies alisadas.

Números de inventário antigos: MNA 3:950 (número vermelho) e MNA 7151.

\section{MNA 997.73.3}

Pequena taça em calote aberta, apresentando $5,7 \mathrm{~cm}$ de diâmetro externo, $4,9 \mathrm{~cm}$ de diâmetro interno e 5,1 cm de diâmetro do bojo. Regista $2,5 \mathrm{~cm}$ de altura e $2 \mathrm{~cm}$ de profundidade, tendo $0,4 \mathrm{~cm}$ de largura do lábio, 0,7 cm de espessura do bojo e 0,6 cm de espessura do fundo. Apresenta cozedura redutora com arrefecimento parcialmente oxidante, com pasta semi-compacta com abundantes elementos não plásticos de fino calibre (quartzos angulosos e sub-rolados, feldspatos, escassas moscovites), sendo as suas superfícies alisadas.

Número de inventário antigo: MNA 3:949 (número vermelho). 
MNA 997.73 .4

Fragmento de bojo de recipiente indeterminado, com cerca de $0,7 \mathrm{~cm}$ de espessura. Apresenta cozedura redutora com arrefecimento oxidante, com pasta semi-compacta com abundantes elementos não plásticos de fino calibre (quartzos angulosos e sub-rolados, feldspatos), sendo as suas superfícies alisadas.

Número de inventário antigo: MNA 3:950B (número vermelho).

\begin{tabular}{|c|c|c|c|c|c|c|c|c|c|c|c|}
\hline Ref. & Forma & Tipo & Estado & DIA & DEA & DBJ & Alt. & IA & IP & Esp. Brd. & Esp. Bj. \\
\hline 997.73 .1 & A & Taça & Inteiro & 4,7 & 5,5 & 5,2 & 3 & 105,76 & 54,54 & 0,5 & 0,6 \\
\hline 997.73 .2 & F & Taça & Inteiro & 6,7 & 7,8 & 8,5 & 5,8 & 91,76 & 74,36 & 0,7 & 0,9 \\
\hline 997.73 .3 & A & Taça & Inteiro & 4,9 & 5,7 & 5,1 & 2,5 & 111,76 & 43,86 & 0,4 & 0,7 \\
\hline 997.73 .4 & Ind. & Ind. & Bojo & $?$ & $?$ & $?$ & $?$ & $?$ & $?$ & $?$ & 0,7 \\
\hline
\end{tabular}

Fig. 6 - Recipientes cerâmicos: principais medidas de referência. DIA: Diâmetro Interno de Abertura, em cm; DEA: Diâmetro Externo de Abertura, em cm; DBJ: Diâmetro Bojo, em cm; Alt.: Altura Total, em cm; IA: Índice de Abertura (DEA x 100 / DBJ); IP: Índice de Profundidade (Alt. x 100 / DEA); Esp. Brd.: Espessura do Bordo, em cm; Esp. Bj.: Espessura do Bojo, em cm.

\begin{tabular}{|c|c|c|c|c|c|c|c|c|c|}
\hline Ref. & Tipo Bordo & Perfil Bordo & Dir. Bordo & Pasta & Coz. & Arref. & ${\text { ENP } \mathbf{n}^{\circ}}$ & ENP dim. & Trat. Sup. \\
\hline 997.73 .1 & Não esp. & Arredondado & Recto & Semi-comp. & Ox. & Red. & Abundantes & Finos & Alisada \\
\hline 997.73 .2 & Não esp. & Arredondado & Recto & Semi-comp & Red. & Red. & Escassos & Finos & Alisada \\
\hline 997.73 .3 & Não esp. & Arredondado & Recto & Semi-comp & Red. & Ox. & Abundantes & Finos & Alisada \\
\hline 997.73 .4 & $?$ & $?$ & $?$ & Semi-comp & Red. & Ox. & Abundantes & Finos & Alisada \\
\hline
\end{tabular}

Fig. 7 - Recipientes cerâmicos: morfologia do bordo, pastas e acabamentos.
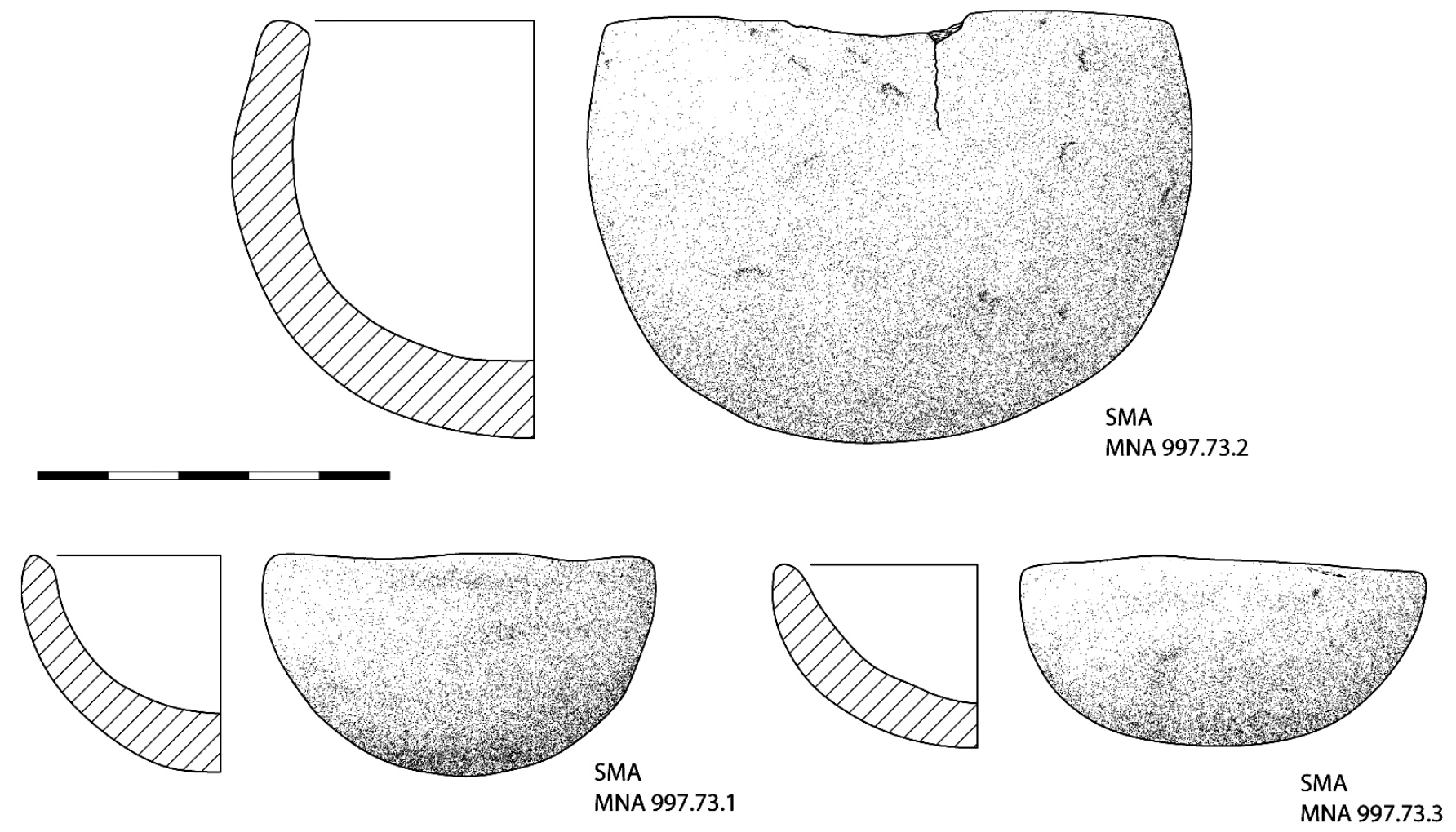

Fig. 8 - Recipientes cerâmicos da «sepultura» do Sobral do Martim Afonso: MNA 997.73.2, 997.73.1 e 997.73.3. 


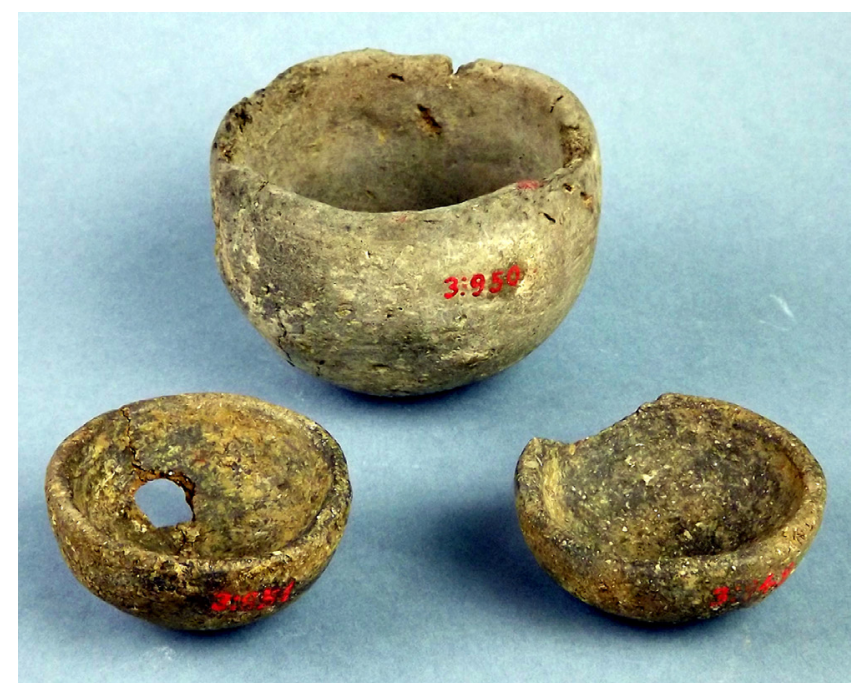

Fig. 9 - Recipientes cerâmicos da «sepultura» do Sobral do Martim Afonso: MNA 997.73.2, 997.73.1 e 997.73.3. Diâmetro externo do recipiente maior: $7,8 \mathrm{~cm}$.

\section{Artefactos de pedra lascada}

Nesta categoria contam-se nove elementos: uma pequena alabarda (MNA 997.73.6) e oito lâminas (MNA 997.73.7 a 14), qualquer um deles usando sílex como suporte. Descrevem-se da seguinte forma:

\section{MNA 997.73.6}

Pequena alabarda (ou grande ponta de dardo) de sílex, de contorno sensivelmente triangular, com base igualmente triangular (esboçando uma espécie de pedúnculo sensível) e perfil rectilíneo. Apresenta $10,9 \mathrm{~cm}$ de altura total $(10 \mathrm{~cm}$, descontando a área basal pedunculada), 6,7 cm de largura da base, 4,5 $\mathrm{cm}$ de largura mesial e $0,2 \mathrm{~cm}$ de largura do topo (encontrando-se este intacto). Oferece $0,5 \mathrm{~cm}$ de espessura.

Possui retoque bifacial invasor em todo o perímetro da peça (cobridor na extremidade distal), rasante, distribuindo-se entre escamoso a escalariforme; apresenta polimento intenso na área ventral, no anverso e no reverso.

Osílexapresentatonalidadebege-acastanhada, com alguns pequenos zonamentos pontilhados avermelhados (óxidos de ferro) e esbranquiçados, sendo semi-translúcido. Oferece boa qualidade de talhe, sendo de grão fino, com textura mudstone.

Números de inventário antigos: MNA 3:883 (número vermelho) e MNA 7142.

MNA 997.73.7

Lâmina de sílex retocada. Apresenta-se conservada apenas pelas áreas proximal e mesial, correspondendo a um exemplar de fase plena de debitagem, obtida por pressão. O talão é esmagado/ retocado. O bolbo, reduzido, apresenta-se eliminado por retoque. A secção é trapezoidal, apresentando os bordos paralelos (mais estreitos no talão) e nervuras sensivelmente paralelas (2), com perfil convexo.

Apresenta retoque directo contínuo em ambos bordos, abrupto e curto, com levantamentos subparalelos.

Encontra-se aparentemente fracturada por flexão.

Oferece $10,9 \mathrm{~cm}$ de comprimento conservado, com uma largura máxima de $2,5 \mathrm{~cm}$ e mínima de 1,2 $\mathrm{cm}$, com uma espessura máxima de $0,9 \mathrm{~cm}$ e mínima de $0,6 \mathrm{~cm}$.

O sílex apresenta tonalidade castanhaesverdeada, com alguns pequenos zonamentos pontilhados avermelhados (óxidos de ferro), sendo semi-translúcido. Oferece boa qualidade de talhe, sendo de grão fino, com textura mudstone.

Números de inventário antigos: MNA 3:879 (número vermelho) e MNA 7147.

\section{MNA 997.73 .8}

Lâmina de sílex retocada. Apresenta-se conservada apenas pelas áreas mesial e distal, correspondendo a um exemplar de fase plena de debitagem, obtida por pressão. $O$ talão e o bolbo, por fractura da peça, são indetermináveis. A secção é trapezoidal, apresentando os bordos e nervuras (2) paralelos, com perfil convexo.

Apresenta retoque directo contínuo em ambos bordos, abrupto e curto, com levantamentos sub-paralelos. Apresenta igualmente retoque na extremidade distal (retoque «em leque»).

Encontra-se aparentemente fracturada por flexão.

Oferece $10,1 \mathrm{~cm}$ de comprimento conservado, com uma largura máxima de $1,7 \mathrm{~cm}$ e mínima de 1 $\mathrm{cm}$, com uma espessura máxima de $0,7 \mathrm{~cm}$ e mínima de $0,5 \mathrm{~cm}$.

O sílex apresenta tonalidade cinzentaesverdeada, com alguns pequenos zonamentos pontilhados esbranquiçados, sendo semi-translúcido. Oferece boa qualidade de talhe, sendo de grão fino, com textura mudstone.

Números de inventário antigos: MNA 3:881 (número vermelho) e MNA 7148.

MNA 997.73.9

Lâmina de sílex retocada. Apresenta-se 
conservada apenas pela área mesial, correspondendo a um exemplar de fase plena de debitagem, com córtex vestigial, obtida por pressão. O talão e o bolbo, por fractura da peça, são indetermináveis. A secção é trapezoidal, apresentando os bordos e nervuras (2) paralelos, com perfil convexo.

Apresenta retoque directo contínuo em ambos bordos, semi-abrupto e curto, com levantamentos paralelos. flexão.

Encontra-se aparentemente fracturada por

Oferece $6,9 \mathrm{~cm}$ de comprimento conservado, com uma largura máxima de $2,4 \mathrm{~cm}$ e mínima de 1,8 $\mathrm{cm}$, com uma espessura máxima de $0,7 \mathrm{~cm}$ e mínima de $0,5 \mathrm{~cm}$.

O sílex apresenta tonalidade castanhaesverdeada, com alguns pequenos zonamentos pontilhados avermelhados (óxidos de ferro) e esbranquiçados, sendo semi-translúcido. Oferece boa qualidade de talhe, sendo de grão fino, com textura mudstone.

Números de inventário antigos: MNA 3:880 (número vermelho) e MNA 7150.

\section{MNA 997.73.10}

Lâmina de sílex retocada. Apresenta-se inteira, correspondendo a um exemplar de fase plena de debitagem, obtida por pressão. O talão é esmagado/ retocado. $\mathrm{O}$ bolbo, reduzido, apresenta-se eliminado por retoque. A secção é trapezoidal, apresentando os bordos bi-convexos e nervuras divergentes (2), com perfil convexo.

Apresenta retoque directo contínuo em ambos bordos, abrupto e curto, com levantamentos de sub-paralelos a escamosos (principalmente no bordo direito). Apresenta igualmente retoque na extremidade distal (retoque «em leque»).

Oferece $14,9 \mathrm{~cm}$ de comprimento, com uma largura máxima de $2,8 \mathrm{~cm}$ e mínima de $1 \mathrm{~cm}$, com uma espessura máxima de $0,9 \mathrm{~cm}$ e mínima de 0,4 $\mathrm{cm}$.

O sílex apresenta tonalidade castanhaesverdeada, com alguns pequenos zonamentos pontilhados avermelhados (óxidos de ferro) e esbranquiçados, sendo semi-translúcido. Oferece boa qualidade de talhe, sendo de grão fino, com textura mudstone.

Números de inventário antigos: MNA 3:878 (número vermelho) e MNA 7144.

MNA 997.73.11

Lâmina de sílex não retocada. Apresenta-se conservada apenas pelas áreas proximal e mesial (faltando apenas uma pequena parte da extremidade distal), correspondendo a um exemplar de fase plena de debitagem, obtida por percussão indirecta. O talão é diédrico. O bolbo, nítido, apresenta-se esquirolado. A secção é triangular, apresentando os bordos paralelos com talão estreito, com perfil convexo.

Encontra-se aparentemente fracturada acidentalmente.

Oferece $13,3 \mathrm{~cm}$ de comprimento conservado, com uma largura máxima de $2,5 \mathrm{~cm}$ e mínima de 1,5 $\mathrm{cm}$, com uma espessura máxima de $0,8 \mathrm{~cm}$ e mínima de $0,4 \mathrm{~cm}$.

O sílex apresenta tonalidade castanhaesverdeada, com alguns pequenos zonamentos pontilhados avermelhados (óxidos de ferro) e esbranquiçados, sendo semi-translúcido. Oferece boa qualidade de talhe, sendo de grão fino, com textura mudstone.

Números de inventário antigos: MNA 3:875 (número vermelho) e MNA 7143.

\section{MNA 997.73 .12}

Lâmina de sílex retocada. Apresenta-se inteira, correspondendo a um exemplar de fase plena de debitagem, obtida por pressão. O talão é esmagado/ retocado. $\mathrm{O}$ bolbo, reduzido, apresenta-se eliminado por retoque. A secção é trapezoidal, apresentando os bordos paralelos e nervuras convergentes (2), com perfil mesial direito e perfil distal convexo.

Apresenta retoque directo contínuo no bordo esquerdo (terço proximal), semi-abrupto e curto, com levantamentos sub-paralelos. Apresenta igualmente retoque nas extremidades distal (retoque «em leque») e proximal.

Oferece $10,4 \mathrm{~cm}$ de comprimento, com uma largura máxima de $1,8 \mathrm{~cm}$ e mínima de $0,9 \mathrm{~cm}$, com uma espessura máxima de 0,6 cm e mínima de 0,3 $\mathrm{cm}$.

O sílex apresenta tonalidade castanhaesverdeada, com alguns pequenos zonamentos pontilhados avermelhados (óxidos de ferro) e esbranquiçados, sendo semi-translúcido. Oferece boa qualidade de talhe, sendo de grão fino, com textura mudstone.

Números de inventário antigos: MNA 3:882 (número vermelho) e MNA 7149.

\section{MNA 997.73.13}

Lâmina de sílex retocada. Apresenta-se inteira, correspondendo a um exemplar de fase plena de debitagem, obtida por pressão. $O$ talão é esmagado/ 

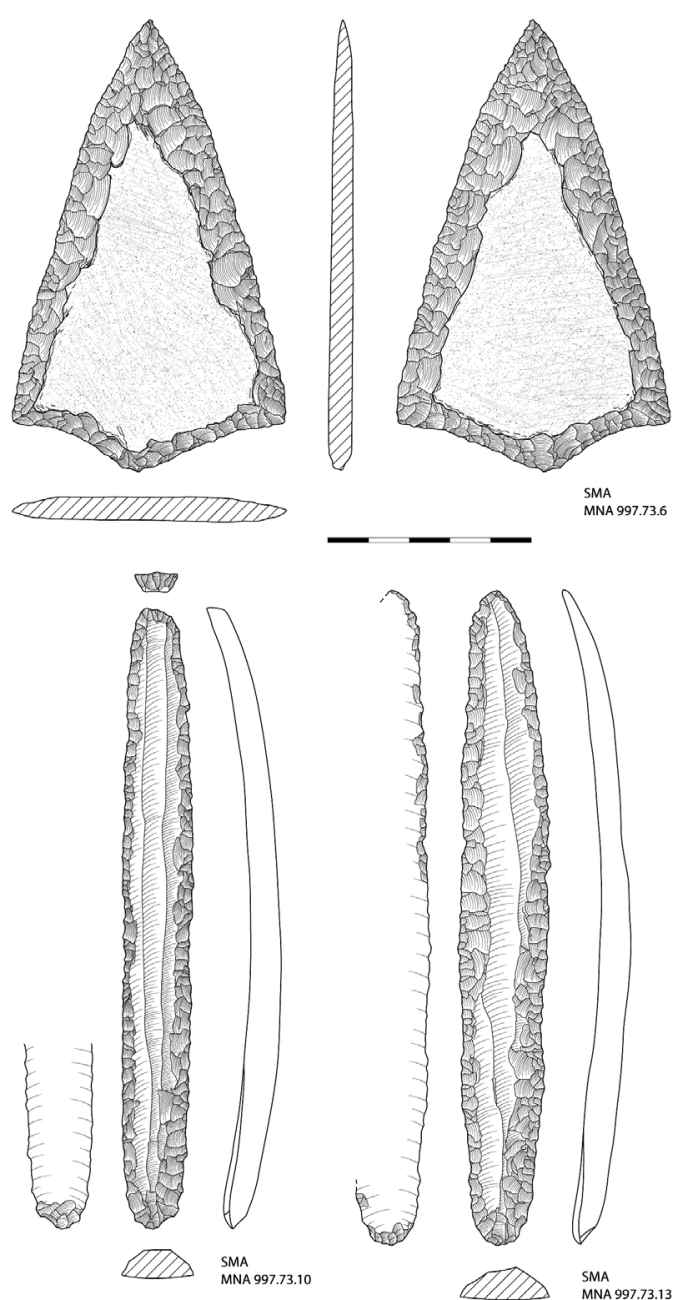

Fig. 10 - Artefactos de pedra lascada da «sepultura» de Sobral do Martim Afonso: alabarda MNA 997.73.6 e lâminas retocadas MNA 997.73.10 e 997.73.13.

retocado. O bolbo, reduzido, apresenta-se eliminado por retoque. A secção é trapezoidal, apresentando os bordos bi-convexos e nervuras irregulares (2), com perfil mesial direito e perfil distal convexo.

Apresenta retoque directo contínuo em ambos bordos (bifacial no terço distal do bordo esquerdo), semi-abrupto, de curto a longo, com levantamentos de sub-paralelos a escamosos. Apresenta igualmente retoque na extremidade distal (retoque «em leque») e proximal.

Oferece $15,8 \mathrm{~cm}$ de comprimento, com uma largura máxima de $2,3 \mathrm{~cm}$ e mínima de $0,7 \mathrm{~cm}$, com uma espessura máxima de $0,8 \mathrm{~cm}$ e mínima de 0,3 $\mathrm{cm}$.

O sílex apresenta tonalidade castanhaesverdeada, com alguns pequenos zonamentos pontilhados avermelhados (óxidos de ferro) e

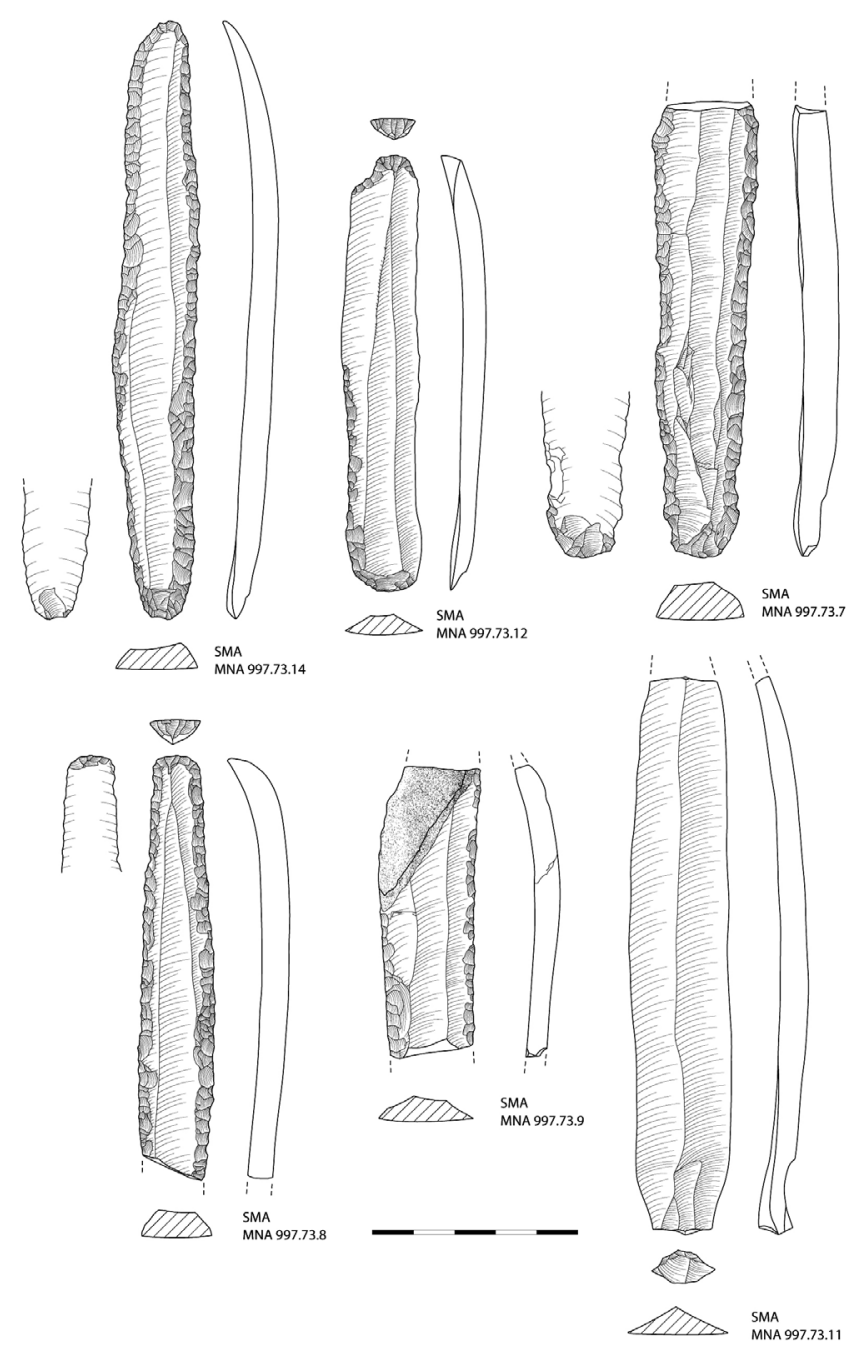

Fig. 11 - Artefactos de pedra lascada da «sepultura» de Sobral do Martim Afonso: lâminas retocadas MNA 997.73.14, 997.73.12, 997.73.7, 997.73.8, 997.73.9 e lâmina bruta MNA 997.73.11.

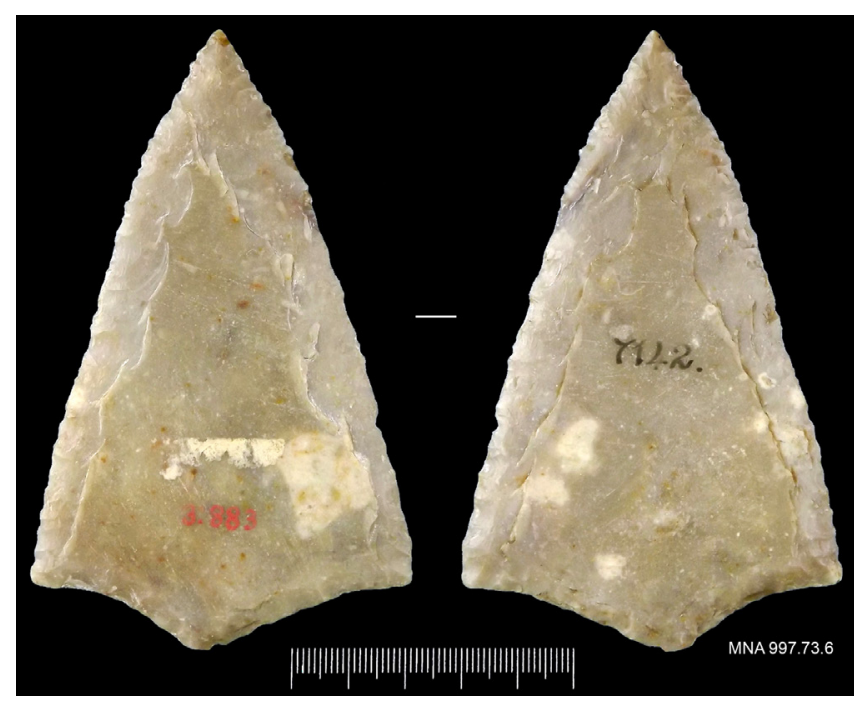

Fig. 12 - Alabarda da «sepultura» do Sobral do Martim Afonso: MNA 997.73.6. 
esbranquiçados, sendo semi-translúcido. Oferece boa qualidade de talhe, sendo de grão fino, com textura mudstone.

Números de inventário antigos: MNA 3:877 (número vermelho) e MNA 7145.

\section{MNA 997.73.14}

Lâmina de sílex retocada. Apresenta-se inteira, correspondendo a um exemplar de fase plena de debitagem, obtida por pressão. O talão é esmagado/ retocado. $O$ bolbo, reduzido, apresenta-se eliminado por retoque. A secção é trapezoidal, apresentando

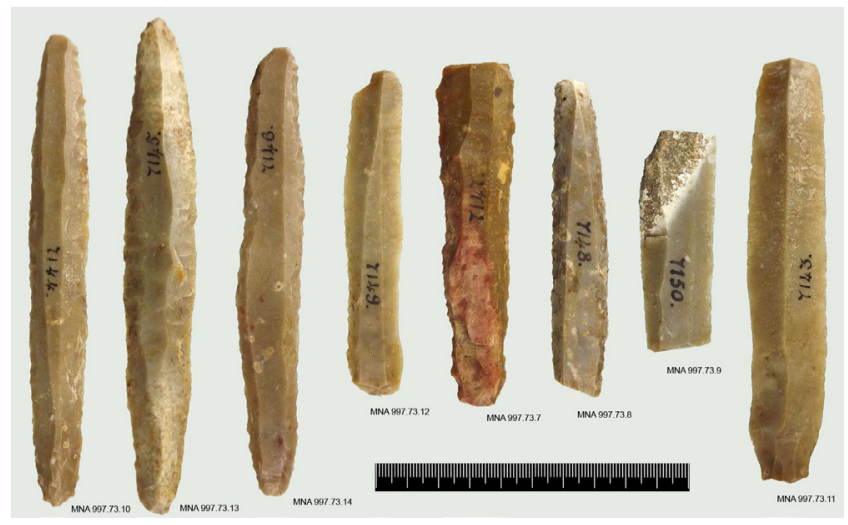

Fig. 13 - Lâminas da «sepultura» do Sobral do Martim Afonso: MNA 997.73.10, 997.73.13, 997.73.14, 997.73.12, 997.73.7, 997.73.8, 997.73.9 e 997.73.11.

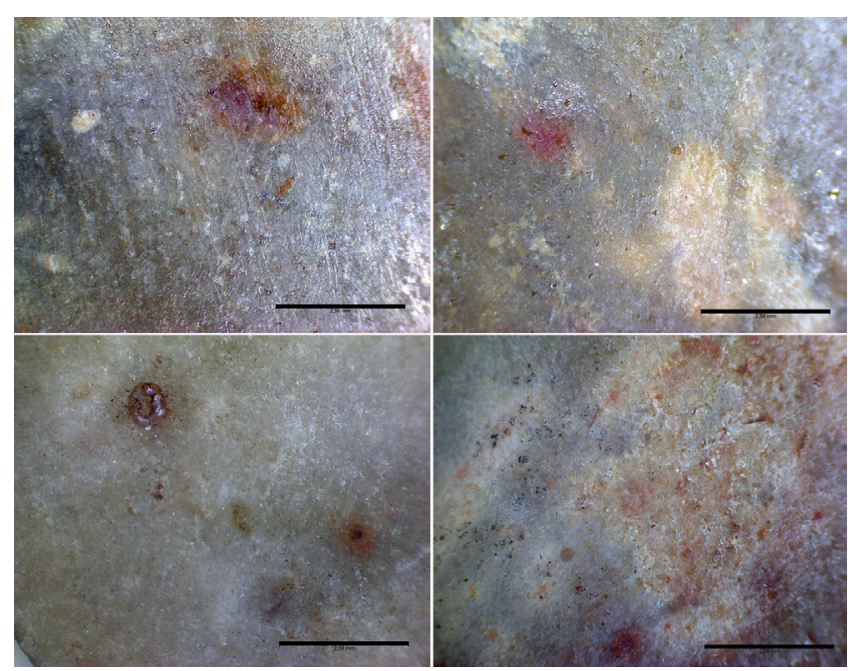

Fig. 14 - Aspecto microscópico (x50) do sílex utilizado nos artefactos de pedra lascada da «sepultura» de Sobral do Martim Afonso. A: alabarda MNA.997.73.6; B-D lâminas MNA 997.73.7, 997.73.11 e 997.73.14. Correspondem qualquer um deles a sílices geologicamente atribuíveis ao Cenomaniano superior, evidenciando-se a presença de micro-quartzos e óxidos de ferro, característico das silicificações cenomanianas da Alta Estremadura portuguesa. A escala corresponde a 2,5 mm. os bordos paralelos com talão estreito e nervuras sensivelmente paralelas (2), com perfil mesial direito e perfil distal convexo.

Apresenta retoque directo contínuo em ambos bordos, abrupto, curto, com levantamentos sub-paralelos. Apresenta igualmente retoque na extremidade distal (retoque «em leque») e proximal.

Oferece $14,3 \mathrm{~cm}$ de comprimento, com uma largura máxima de $2 \mathrm{~cm}$ e mínima de $0,7 \mathrm{~cm}$, com uma espessura máxima de 0,6 cm e mínima de 0,3 $\mathrm{cm}$.

O sílex apresenta tonalidade castanhaesverdeada, com alguns pequenos zonamentos pontilhados avermelhados (óxidos de ferro) e esbranquiçados, sendo semi-translúcido. Oferece boa qualidade de talhe, sendo de grão fino, com textura mudstone.

Números de inventário antigos: MNA 3:876 (número vermelho) e MNA 7146.

\section{Artefactos relacionados com o Sagrado}

Um único elemento se regista nesta categoria, referindo-se a um báculo de xisto ardosiano, referenciado com o número MNA 997.73.5. Apresenta uma altura no eixo vertical principal de cerca de $27,4 \mathrm{~cm}$, com uma largura de $13,8 \mathrm{~cm}$ no topo, $6,4 \mathrm{~cm}$ na área mesial e $2,7 \mathrm{~cm}$ na base. Possui $0,8 \mathrm{~cm}$ de espessura média. 0 motivo exclusivo que se desenvolve em rotação da Cabeça para o limite gravado do cabo é constituído por sete bandas de triângulos preenchidos - a primeira (sendo estas bandas lidas do topo para a base) está gravada com triângulos preenchidos com o vértice para baixo, as seis restantes estão gravadas com triângulos preenchidos com o vértice para cima, qualquer uma composta por quatro triângulos. Apresenta assim a seguinte composição (lida no sentido da cabeça para a empunhadura):

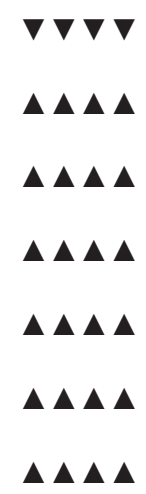


Os triângulos junto aos bordos encontramse truncados, exceptuando o da primeira banda junto ao bordo interior. Estas bandas, dispostas simetricamente em relação à curvatura da peça, apresentam espessuras variáveis, sendo mais amplas junto ao bordo exterior e menos amplas junto ao bordo interior. Apresentam as seguintes espessuras médias: $4,5 \mathrm{~cm} / 4,8 \mathrm{~cm} / 4,9 \mathrm{~cm} / 4,1 \mathrm{~cm} / 2,8 \mathrm{~cm} / 2,4$ $\mathrm{cm} / 3,5 \mathrm{~cm}$.

O espaço de reserva no cabo («empunhadura»), sem decoração, atinge os $6,9 \mathrm{~cm}$.

Número de inventário antigo: MNA 7154.

Os contornos da decoração encontram-se «reforçados» com grafite, acção realizada em data incerta - e que trabalhos realizados no Laboratório de Conservação e Restauro do MNA, com solventes vários, não conseguiram remover por completo (e que a Grande Mãe fulmine, com os seus Sóis flamejantes e irascível justiça, a mão ímpia do seu indigno autor)...

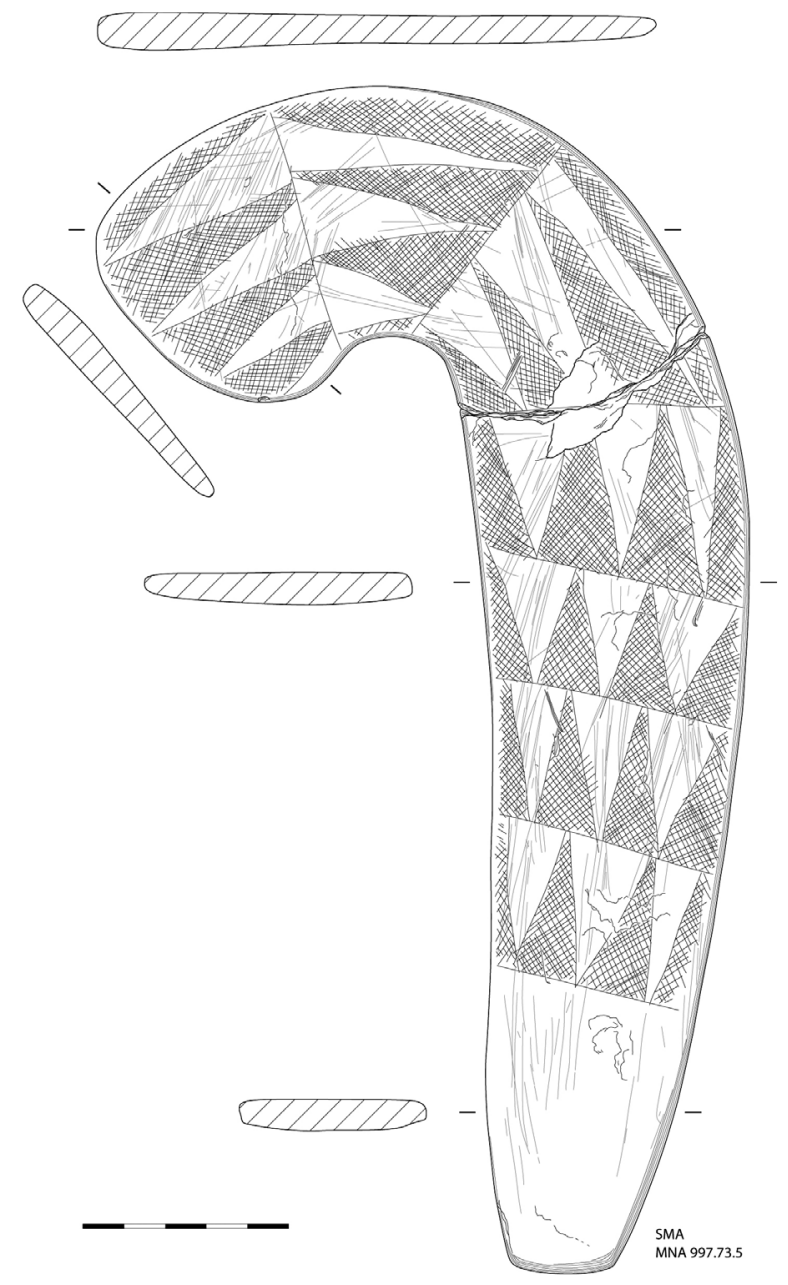

Fig. 15 - Báculo de xisto gravado da «sepultura» do Sobral do Martim Afonso: MNA 997.73.5.

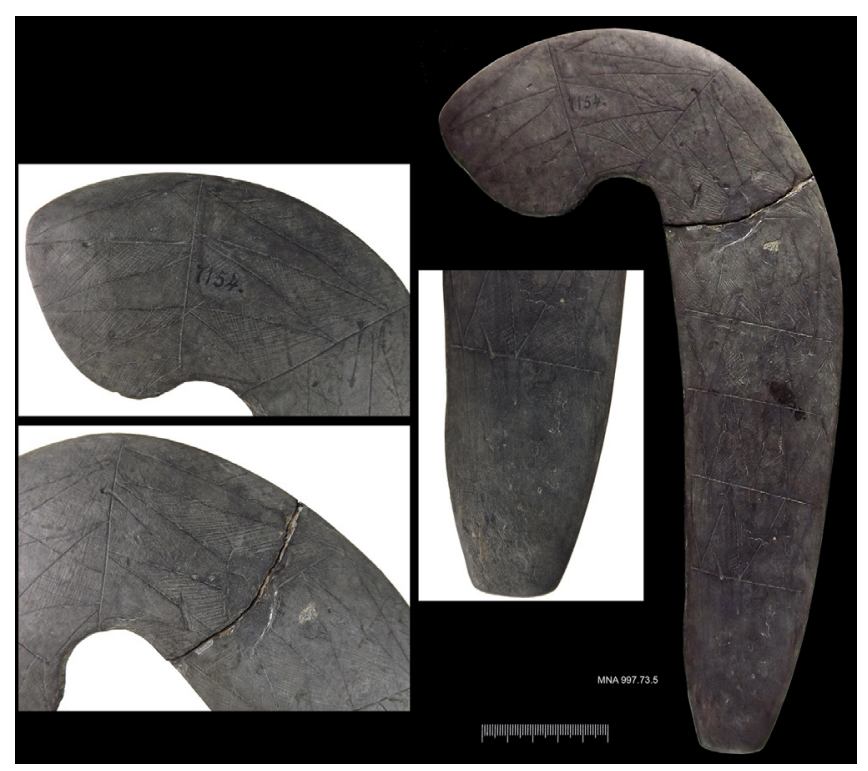

Fig. 16 - Báculo de xisto gravado da «sepultura» do Sobral do Martim Afonso: MNA 997.73.5. à esquerda, pormenores da Cabeça, da área de transição Cabeça-Cabo e da empunhadura lisa.

\section{Espólio osteológico}

Referenciado com o número MNA 997.73.15, encontra-se um conjunto de fragmentos de ossos humanos provenientes da «sepultura» do Sobral do Martim Afonso. Referem-se aos seguintes elementos (classificados com o apoio de Bruno Magalhães): um fragmento de diáfise de fémur direito (MNA 997.73.15a), um fragmento de diáfise de fémur esquerdo (MNA 997.73.15b), um terço distal de úmero direito (MNA 997.73.15c), um fragmento de crânio (MNA 997.73.15d), um fragmento de diáfise de tíbia direita (MNA 997.73.15e) - para além de outros fragmentos inclassificáveis, mas provavelmente pertencentes aos elementos acima descritos, não tendo sido possível (apesar das fracturas recentes) a sua recolagem.

Aparentemente, pertencem a indivíduo adulto (ou jovem-adulto), de género indeterminado, não havendo certezas absolutas de poderem pertencer ao mesmo indivíduo. No entanto, F. Pereira da Costa refere especificamente a recolha de "ossos de um esqueleto» (sublinhado do signatário), o que, aliado à não repetição de elementos (com as reservas devidas à exiguidade da amostra), permite supor que se trata efectivamente de um único indivíduo.

Estes elementos mantêm ainda aderentes às suas superfícies (assim como preenchendo o seu interior) sedimentos de matriz silto-arenosa com pequenos grãos sub-rolados de quartzo - o que 


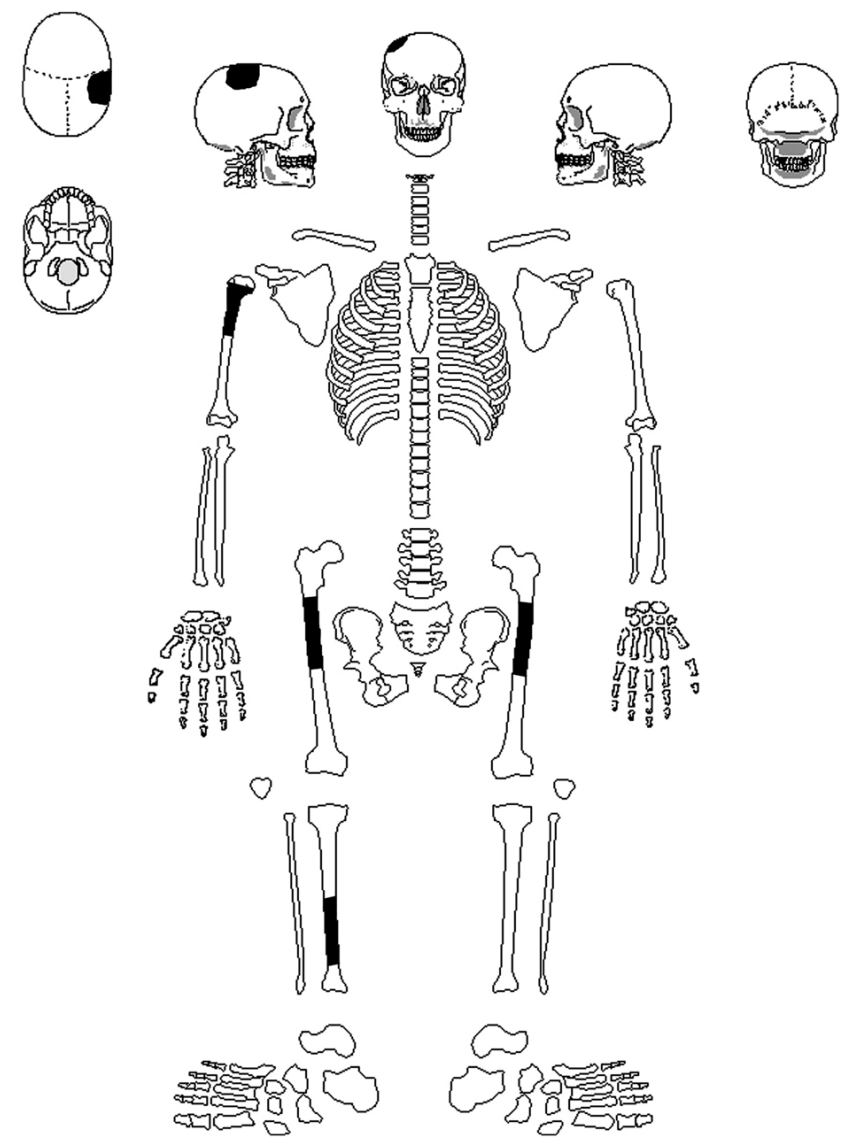

Fig. 17 - Elementos osteológicos conservados da «sepultura» de Sobral do Martim Afonso.

condiz com o contexto geológico aqui reconhecido. Número de inventário antigo: MNA 7155.

\section{O CONTEXTO HABITACIONAL}

O espaço entendido como contexto de habitat encontra-se definido por uma área de cerca de $650 \mathrm{~m} 2$, delimitada pela dispersão de espólio arqueológico. Foram recolhidos artefactos integráveis em distintas categorias: Recipientes cerâmicos, Artefactos de pedra lascada, Artefactos de pedra polida, Artefactos de pedra afeiçoada, Artefactos possivelmente relacionados com o Sagrado, Outros artefactos e objectos.

Foram utilizados para o estudo deste espólio, adaptados à realidade em análise, os critérios descritivos actualmente em uso pelo Grupo de Trabalho sobre as Antigas Sociedades Camponesas da UNIARQ (e expressos, por exemplo, em Gonçalves 1989a; Sousa 2010). Tendo em conta o inerente carácter fraccionado da informação recolhida, referindo-se exclusivamente a recolhas de superfície, esta não será tratada estatisticamente - apresentando-se apenas uma leitura global dos

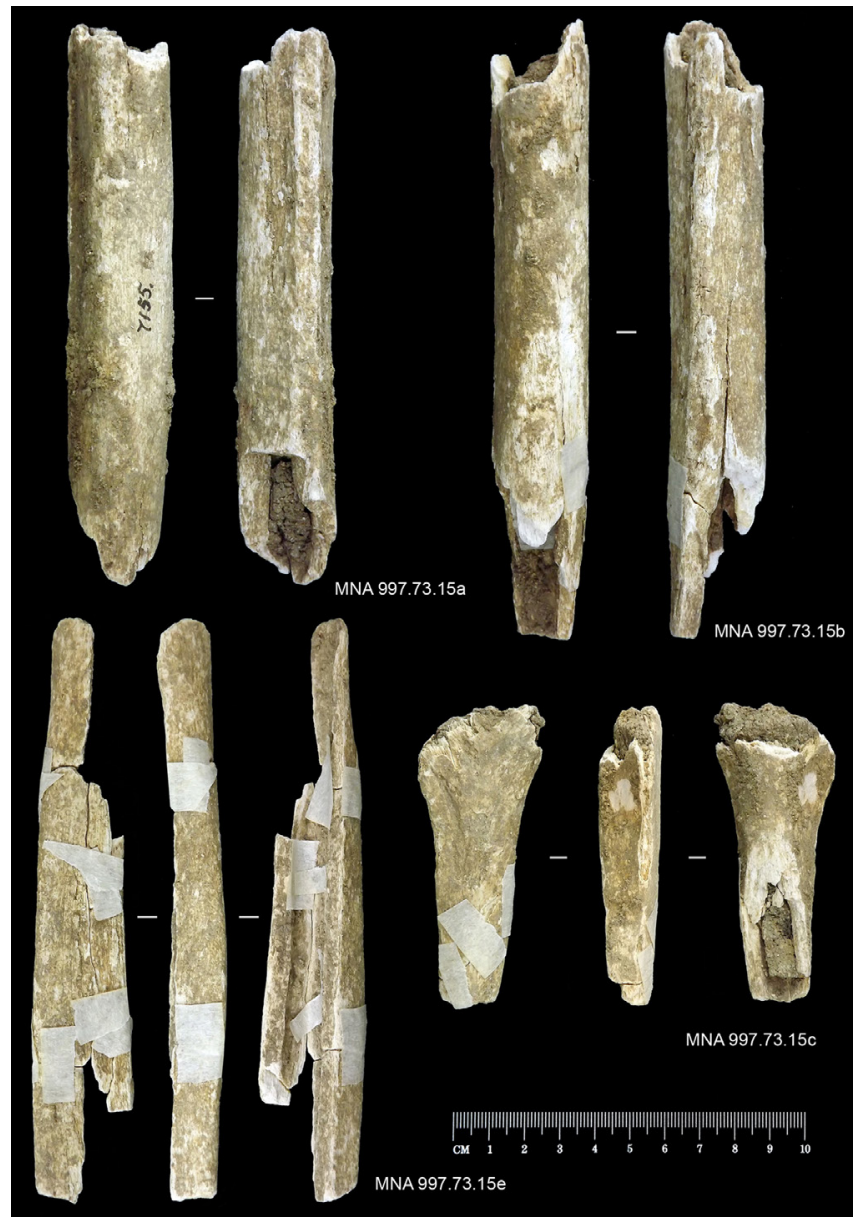

Fig. 18 - Exemplos do espólio osteológico recolhido na «sepultura» de Sobral do Martim Afonso; diáfises de fémur MNA 997.73 15a e 15b, diáfise de tíbia MNA 997.73.15e e terço distal de úmero MNA 997.73.15c.

dados recuperados, baseada nas características genéricas do espólio recolhido.

\section{Recipientes cerâmicos}

Segundo informação do colector, a larga maioria do espólio cerâmico identificado à superfície refere-se a bojos simples, sem qualquer elemento distintivo - pelo que não foram recolhidos à altura.

Em relação aos fragmentos com elementos caracterizadores (neste caso, aqueles que conservam porções de bordo ou motivos decorativos), estes referem-se maioritariamente a formas facilmente integráveis em contextos do Neolítico final e do Calcolítico inicial. O catálogo cerâmico do sítio do Sobral do Martim Afonso oferece, assim, uma relativa variedade morfo-tipológica - característica sumária deste âmbito crono-cultural especifico.

Foram reconhecidos pratos de bordo espessado (incluindo um exemplar com bordo 


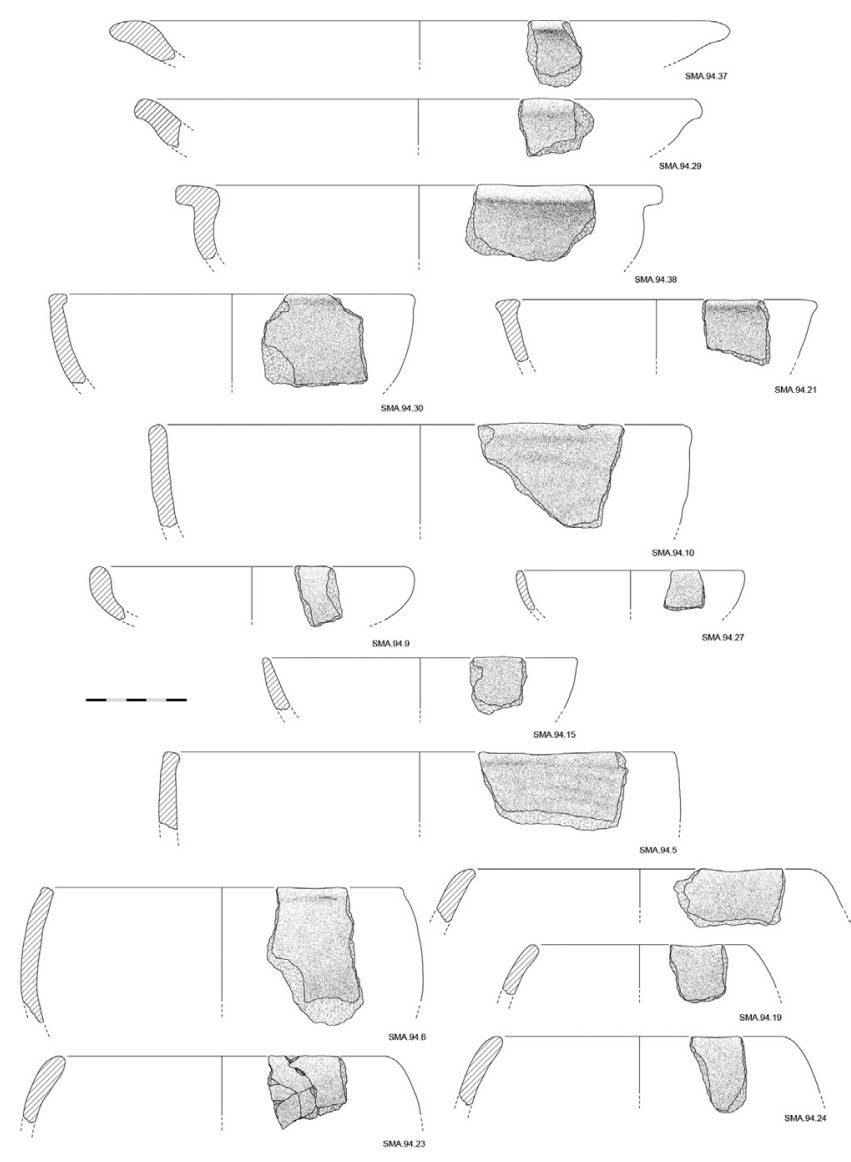

Fig. 19 - Exemplos do espólio cerâmico recolhido no «contexto habitacional» do sítio do Sobral do Martim Afonso: pratos (SMA.94. 37 e SMA.94.29); taça de bordo em aba (SMA.94.38); taças de bordo espessado (SMA.94.30 e 21); grande taça aberta (SMA.94.10); taças em calote abertas (SMA.94.9, 27 e 15); esferoidais (SMA.94.5, 6, 19, 23 e 24).

almendrado, SMA.94.37), grandes taças de bordo em aba (SMA.94.38), taças de bordo bi-espessado, taças em calote abertas, esferoidais, taças em calote fechadas, taças de bordo envasado (SMA.94.11), potes de bordo espessado e taças carenadas (SMA.94.16). Recolheu-se ainda um fragmento de um possível fundo de vaso troncocónico (SMA.94.36), elemento que oferece algumas particularidades interessantes, debatidas mais à frente.

A nível de fabrico, o conjunto dos recipientes cerâmicos recolhidos no contexto habitacional do Sobral do Martim Afonso mostra-se muito homogéneo. Apresentam pastas compactas a semi-compactas, homogéneas, com cozeduras e arrefecimentos maioritariamente oxidantes, com abundantes elementos não plásticos, de calibre fino a médio (maioritariamente correspondendo a grãos sub-rolados de quartzo, com valores

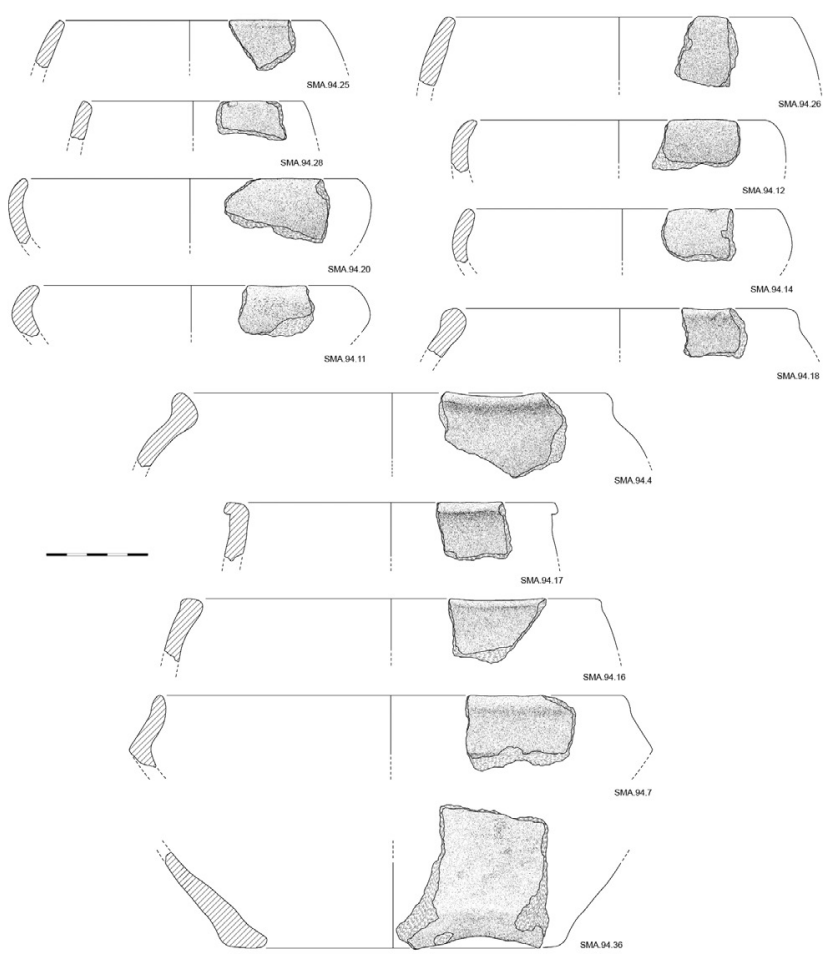

Fig. 20 - Exemplos do espólio cerâmico recolhido no «contexto habitacional» do sítio do Sobral do Martim Afonso: esferoidais (SMA.94.25, 26, 28 e 12); taças em calote fechadas (SMA.94.20 e 14); taça de bordo envasado (SMA.94.11); potes de bordo espessado (SMA.94.18, 4, 17 e 16); taça carenada (SMA.94.7); fundo de recipiente de troncocónico (SMA.94.36)

percentualmente inferiores de feldspatos, moscovites e hematites), apresentando superfícies de rugosas a alisadas (registando-se um elemento possivelmente cepilhado).

As argilas usadas na sua produção são aparentemente locais, tendo em conta as características petrográficas dos componentes não plásticos. Um único elemento se destaca neste conjunto, apresentando pasta pouco compacta, com cozedura redutora, registando-se a presença de negativos de elementos calcários deteriorados durante a cozedura.

Em relação aos recipientes decorados, estes encontram-se representados por apenas dois elementos.

O primeiro (SMA.94.13) corresponde a um fragmento de um pequeno recipiente de paredes rectas com cerca de $10 \mathrm{~cm}$ de diâmetro externo, de superfíciespolidas,compastacompactaehomogénea, com elementos não plásticos de calibre muito fino, apresentando uma canelura larga e pouco profunda abaixo da linha do bordo. Morfologicamente (a nível 


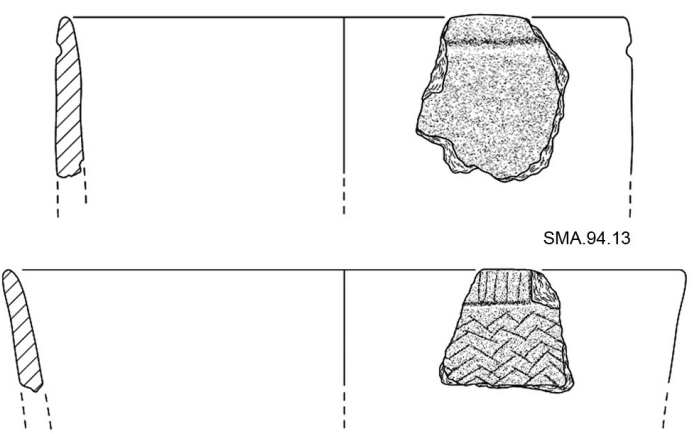

SMA. 94.22
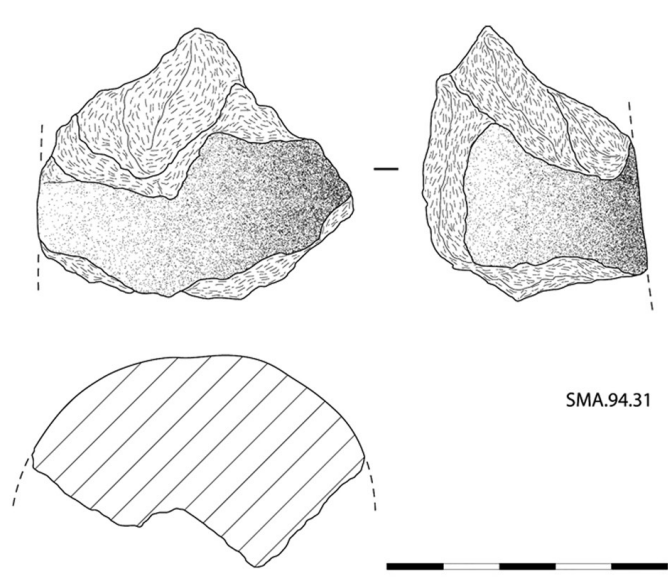

SMA.94.31

Fig. 21 - Exemplos do espólio cerâmico recolhido no «contexto habitacional» do sítio do Sobral do Martim Afonso: recipientes de paredes rectas («copo») com canelura abaixo do bordo (SMA.94.13); vaso campaniforme com decoração incisa (SMA.94.22); fragmento de «ídolo de cornos» (SMA.94.31).

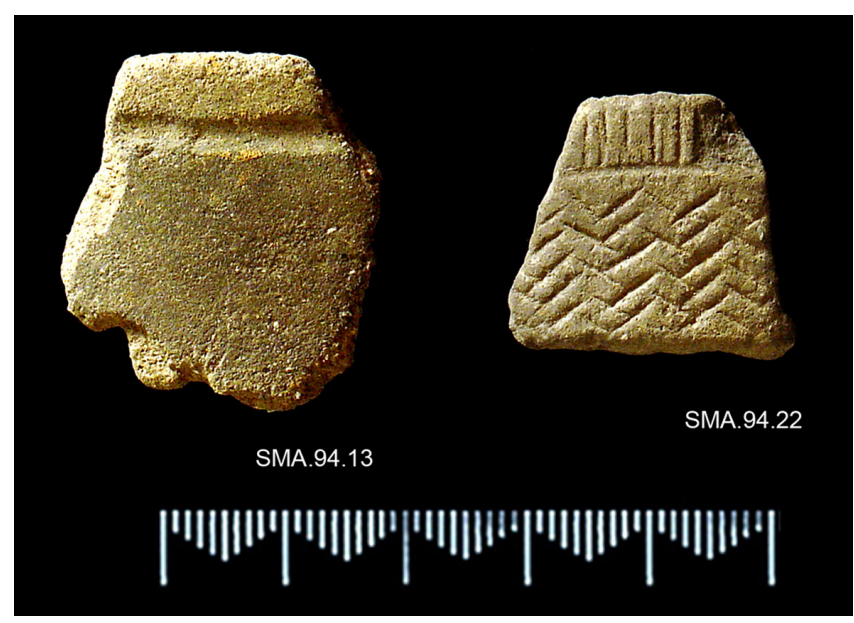

Fig. 22 - Copo canelado (SMA.94.13) e vaso campaniforme (SMA.94.22) recolhidos no «contexto habitacional» do sítio do Sobral do Martim Afonso.

do tratamento de superfícies, das características da pasta e da decoração) poder-se-á fazer equiparar este elemento aos típicos copos canelados do Calcolítico inicial da Península de Lisboa - o que se coaduna, cronologicamente, com o conjunto analisado.

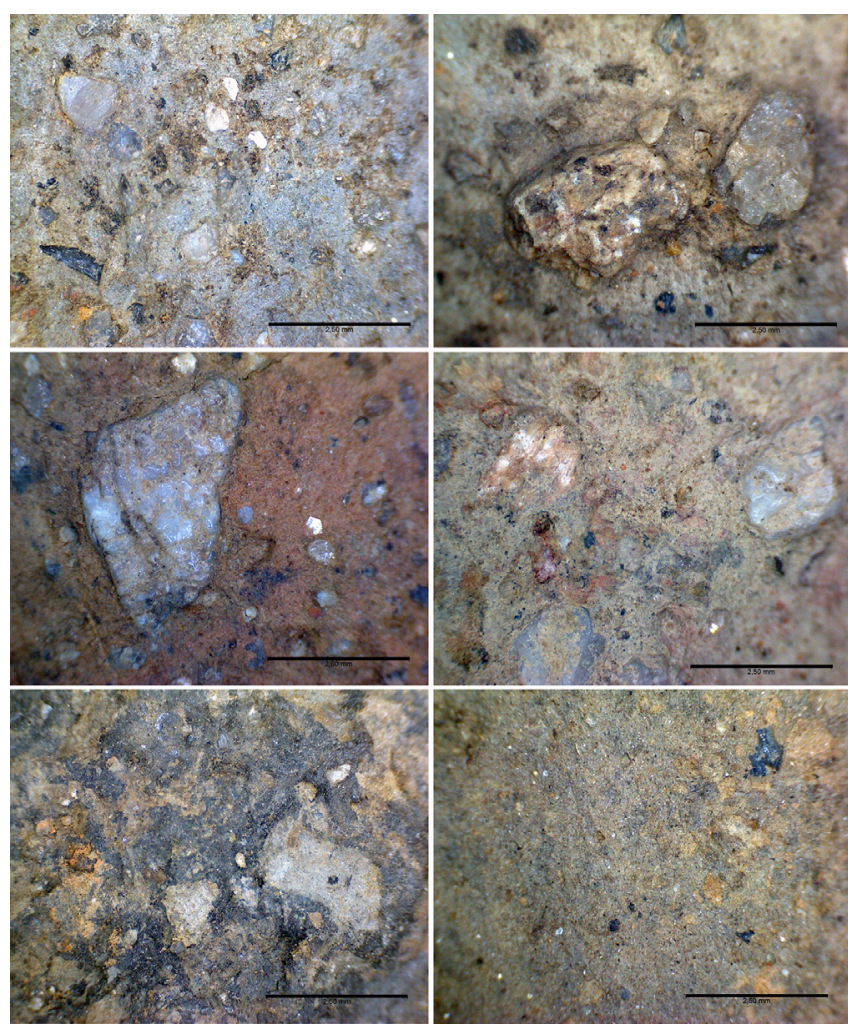

Fig. 23 - Aspecto microscópico (x50) das pastas dos fragmentos de recipientes cerâmicos recolhidos no «contexto habitacional» do Sobral do Martim Afonso. Evidencia-se a presença de elementos não plásticos constituídos maioritariamente por grãos de quartzo subrolados e, em menor número, de feldspatos, moscovites e hematites (imagens $A-D$ ). A imagem $E$ mostra a presença de elementos calcários deteriorados durante a cozedura. $\mathrm{A}$ imagem $\mathrm{F}$, referente ao fragmento campaniforme, mostra o calibre mais fino dos elementos não plásticos, em relação àqueles atribuíveis ao Neolítico final/Calcolítico (restantes imagens). A escala corresponde a 2,5 mm.

O segundo (SMA.94.22), já cronologicamente mais avançado em relação ao geral do conjunto, refere-se ao fragmento de bordo de um vaso campaniforme com decoração incisa. A orientação do bordo (sendo exvasado) poderá indicar que se trata de um pequeno vaso acampanado, mais do que uma caçoila (tendo em consideração o escasso diâmetro que apresenta, sendo este de cerca de $12 \mathrm{~cm}$ externos). A sua decoração compõe-se por incisões oblíquas-horizontais acopladas, formando uma espécie de linhas ziguezagueantes horizontais (ou, dependendo da tendência de leitura, de bandas em espinha verticais). Este motivo decorativo encontra-se encimado por uma banda de métopes incisas disposta abaixo da linha do bordo. Encontrase, assim e aparentemente, incluído nos conjuntos 


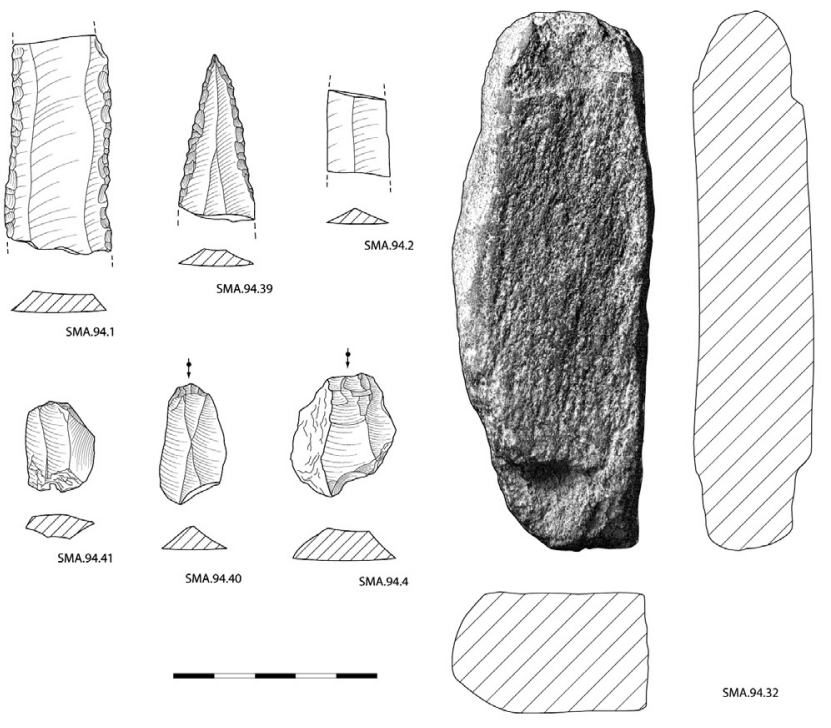

Fig. 24 - Exemplos do espólio lítico (talhado e polido) recolhido no «contexto habitacional» do sítio do Sobral do Martim Afonso: grande lâmina de sílex retocada (SMA.94.1); furador sobre lâmina de sílex (SMA.94.39); lâmina de sílex simples (SMA.94.2); núcleo tabular de lamelas (SMA.94.41); «flanco de núcleo» de sílex (SMA.94.40); «flanco de núcleo» com superfícies patinadas (SMA.94.3); possível «bloco-lingote» de rocha anfibólica com superfícies sumariamente polidas (SMA.94.32).

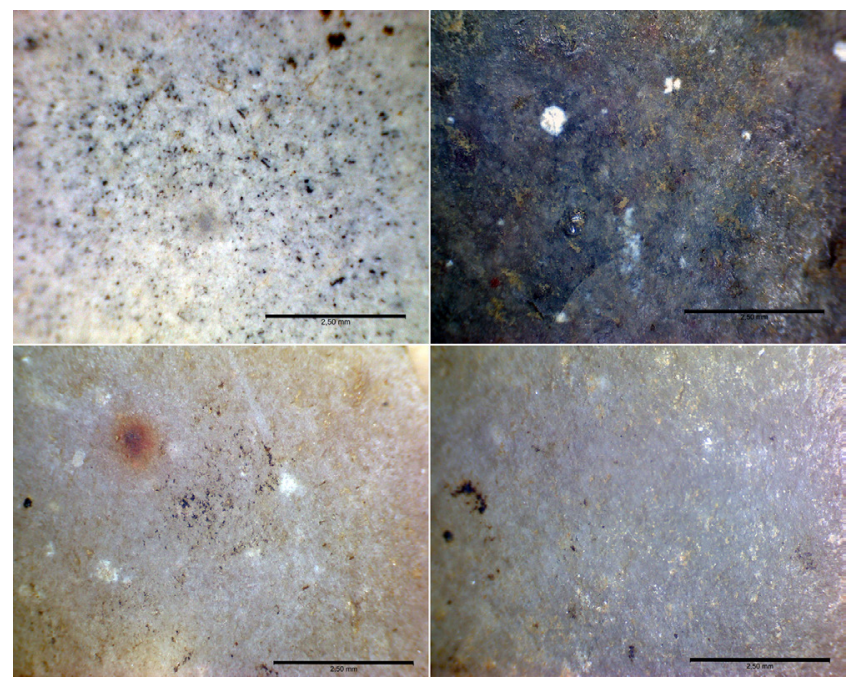

Fig. 25 - Aspecto microscópico (x50) do sílex utilizado nos artefactos de pedra lascada do "contexto habitacional» do sítio do Sobral do Martim Afonso. A: lâmina SMA.94.1, geologicamente atribuível ao limite Batoniano-Bajociano (sem certezas absolutas), com presença de escassos óxidos de ferro e elementos lenticulares negros de origem indeterminada, B: lâmina SMA.94.2, geologicamente atribuível ao Cenomaniano superior, evidenciando-se a presença de micro-quartzos, fissuras preenchidas por calcedónia e óxidos de ferro, característico das silicificações cenomanianas da Alta Estremadura portuguesa. A escala corresponde a $2,5 \mathrm{~mm}$. campaniformes tardios, datáveis do último terço do 3o milénio a.n.e.

Encontram-se ainda no conjunto do Sobral do Martim Afonso dois fragmentos de bordos de «panelas» da Idade do Ferro, obviamente já afastados do âmbito cronológico abordado neste trabalho.

\section{Artefactos de pedra lascada}

O conjunto de artefactos de pedra lascada é escasso, mas ainda assim característico desta etapa cronológica. O espólio em sílex, para além de alguns poucos restos de talhe, compreende um fragmento de uma grande lâmina retocada (SMA.94.1), um fragmento de lâmina simples (SMA.94.2), um furador sobre lâmina (SMA.94.39), um pequeno núcleo tabular de lamelas de debitagem bipolar (SMA.94.41) e um "flanco de núcleo" (SMA.94.40). Recolheu-se ainda um outro "flanco de núcleo" com superfícies bastante patinadas (SMA.94.32) podendo referirse a períodos cronológicos anteriores à ocupação do Neolítico final/Calcolítico do Sobral do Martim Afonso.

Basicamente, o sílex usado nestes artefactos apresenta tonalidade castanha-amarelada, castanhaesverdeada e castanha avermelhada, com alguns pequenos zonamentos pontilhados avermelhados (óxidos de ferro) e esbranquiçados, sendo semitranslúcido. Oferece boa qualidade de talhe, de grão fino, com textura mudstone. Estas são características típicas da silicificações cenomaninas da Alta Estremadura, patentes por exemplo nas silicificações da área de Amieira-Arruda dos Pisões (cf. Matias 2012).

A lâmina SMA.94.1, contudo, oferece características distintas. Apresenta tonalidade esbranquiçada, com escassos óxidos de ferro e elementos lenticulares negros de origem indeterminada, sendo opaco. Oferece qualidade de talhe relativamente boa, sendo de grão fino, com aparente textura wakestone-packstone - podendo corresponder a sílex geologicamente atribuível ao limite Batoniano-Bajociano (embora uma análise mais rigorosa seja necessária, não havendo certezas absolutas nesta classificação).

Foi recolhido ainda um seixo-núcleo de quartzito (SMA.94.33), usando um seixo achatado como suporte ( $\pm 3 \mathrm{~cm}$ de espessura), com exploração unidireccional por progressão frontal de tipo remontante.

\section{Artefactos de pedra polida}

Enquadrável nesta categoria, apenas foi 


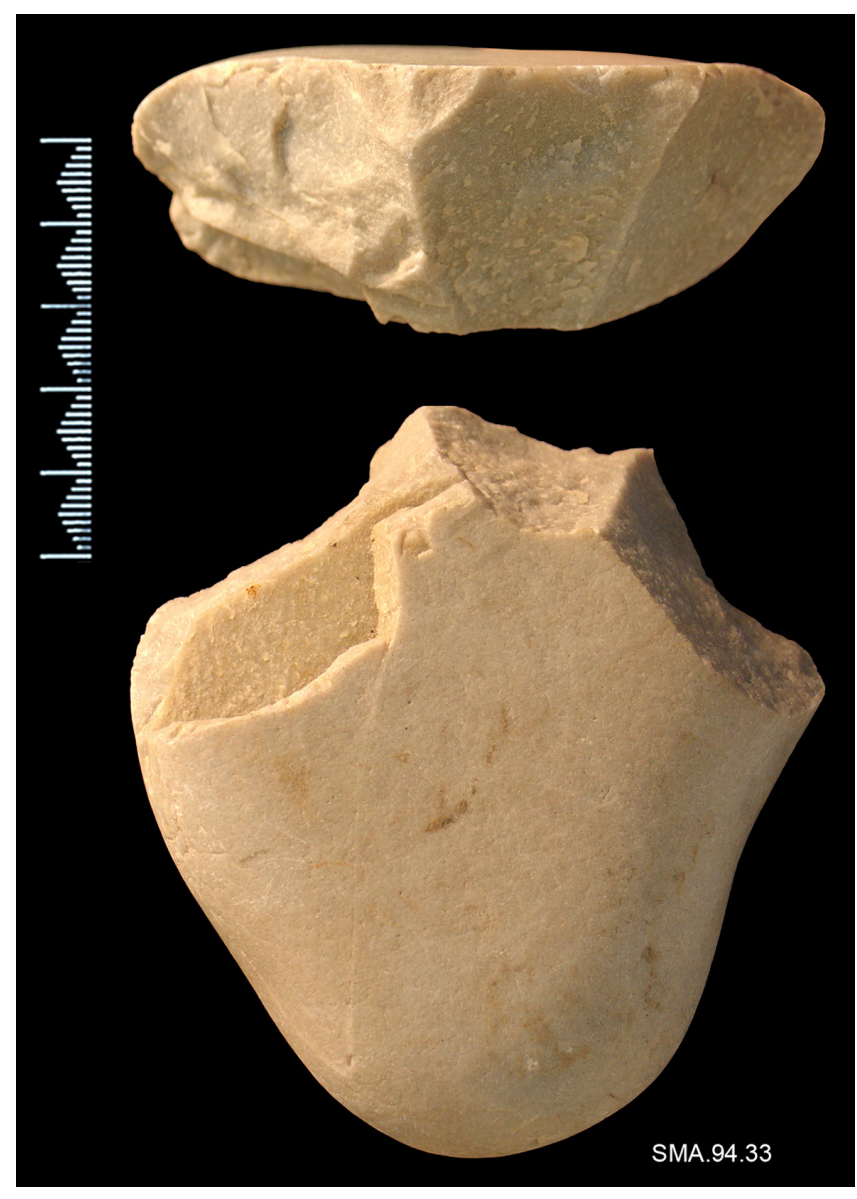

Fig. 26 - Seixo-núcleo de quartzito recolhido no «contexto habitacional» do sítio do Sobral do Martim Afonso (SMA.94.33).

recolhido um único artefacto. Refere-se a um possível «bloco-lingote» de rocha anfibólica, apresentando contorno sub-rectangular, com superfícies desbastadas (resultantes da lascagem de conformação) e polimento sumário na extremidade distal (possível ensaio de polimento). Oferece $8,9 \mathrm{~cm}$ de comprimento, para uma largura máxima de 3,3 $\mathrm{cm}$ e uma espessura média de $2 \mathrm{~cm}$.

\section{Artefactos de pedra afeiçoada}

Esta categoria encontra-se representada por dois componentes.

O primeiro refere-se a uma elemento de moagem (SMA.94.34), usando como suporte granito porfiróide, biotítico. Encontra-se fragmentado, possivelmente por acção térmica. A sua superfície operante não se encontra conservada, pelo que não se poderá estabelecer com precisão a sua funcionalidade.

O segundo corresponde a um percutor de quartzito (SMA.94.35), apresentando superfícies

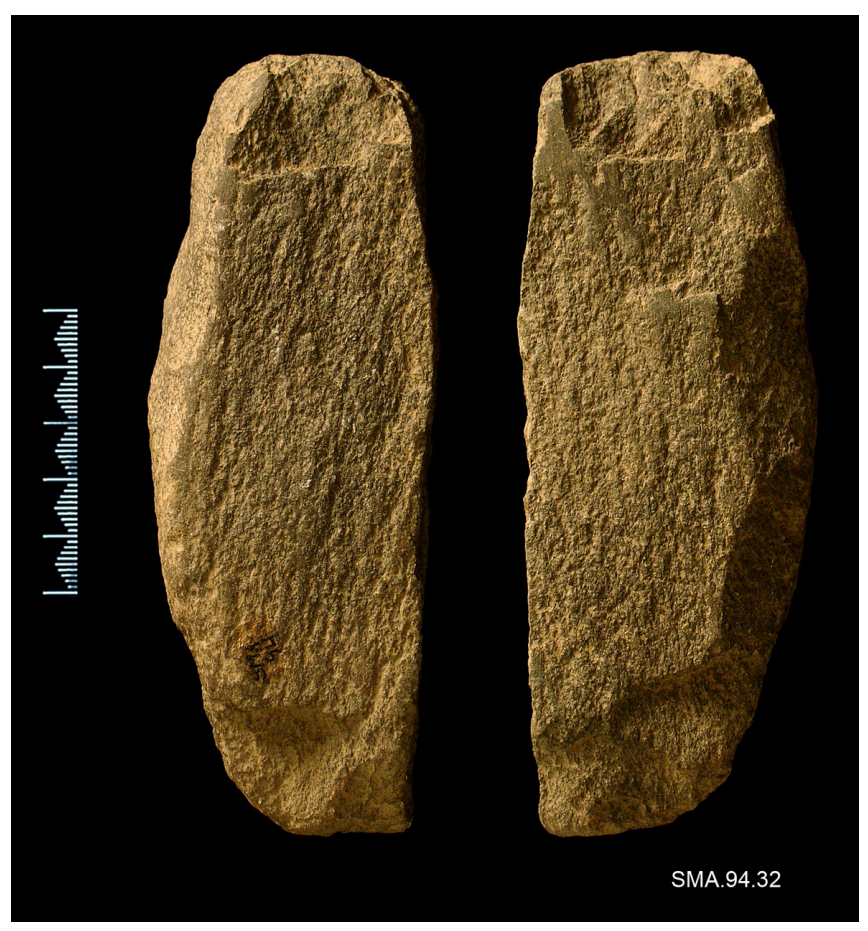

Fig. 27 - Possível «bloco-lingote» de rocha anfibólica recolhido no «contexto habitacional» do sítio do Sobral do Martim Afonso (SMA.94.33).

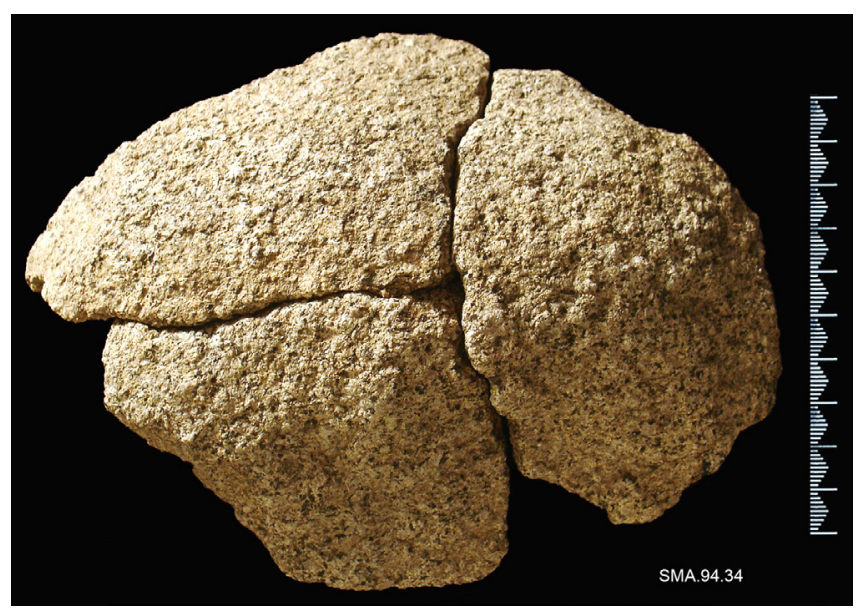

Fig. 28 - Fragmento de elemento de mó de granito recolhido no «contexto habitacional» do sítio do Sobral do Martim Afonso (SMA.94.34).

lascadas e arestas maceradas - correspondendo estas às áreas operantes usadas para percussão. À primeira vista, aparenta tratar-se de um seixonúcleo poliédrico reaproveitado; contudo, os «levantamentos» observados em todo o perímetro da peça poderão corresponder somente, mais do que a efeitos de debitagem intencional, a fracturas de impacto resultantes do seu uso enquanto percutor (com lascagem indesejável do objecto durante a 


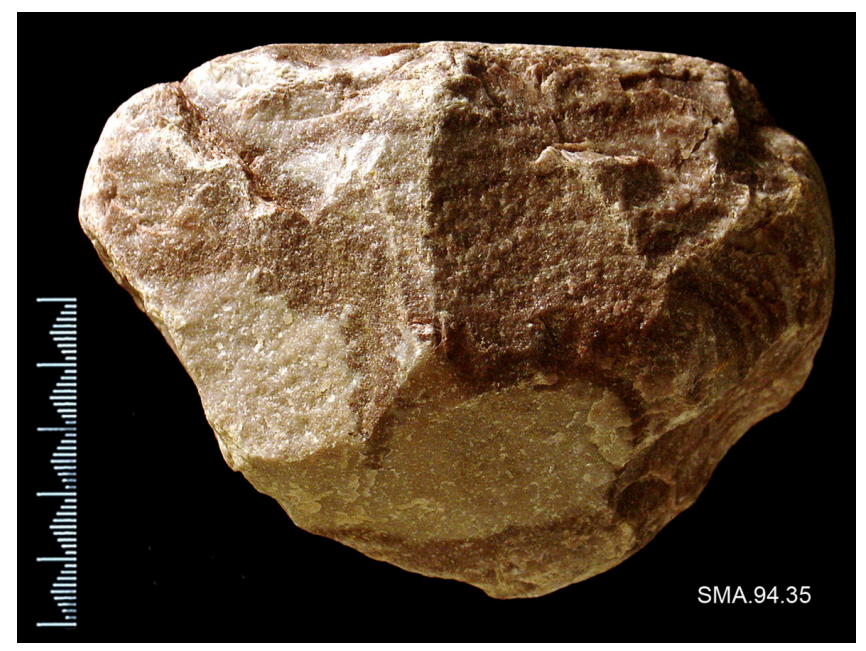

Fig. 29 - Percutor de quartzito, com superfícies lascadas e arestas maceradas, recolhido no «contexto habitacional» do sítio do Sobral do Martim Afonso (SMA.94.35).

percussão). A referida maceração das arestas não permite clarificar com rigor aquela hipótese.

\section{Artefacto possivelmente relacionados com o Sagrado}

Um único elemento se poderá enquadrar nesta categoria (se assumirmos esta interpretação para este tipo de artefactos), referindo-se a um fragmento da área mesial de um «ídolo de cornos» (SMA.94.31). A sua morfologia específica é impossível de definir, dado o estado fragmentado da peça.

Apresenta pasta semi-compacta, homegénea, com elementos não plásticos pouco abundantes, de calibre fino e médio, compostos por grãos de quartzo sub-rolados e feldspatos. Apresenta cozedura redutora e arrefecimento oxidante, tendo as superfícies alisadas.

\section{Outros artefactos e objectos}

Nesta categoria incluem-se apenas os nódulos de «cerâmica de revestimento» recolhidos, alguns conservando negativos de caules. Apresentam pastas alaranjadas, compactas, com grãos de quartzo sub-rolados, de médio calibre.

\section{O SÍTIO PRÉ-HISTÓRICO DO SOBRAL DO MARTIM AFONSO NO CONTEXTO DO NEOLÍTICO FINAL/CALCOLÍTICO DO BAIXO TEJO}

No que concerne especificamente às antigas comunidades camponesas, registam-se na área de Muge ocupações que se estendem do Neolítico antigo ao Calcolítico final - até há bem pouco apenas reconhecidas precisamente pelo espólio funerário de Martim Afonso e pelos fragmentos cerâmicos (do Neolítico antigo) recolhidos nos níveis superiores dos concheiros de Cabeço da Amoreira, Fonte do Padre Pedro, Cova da Onça e Moita do Sebastião (Ferreira 1974; Arnaud 1989; Gomes - Batista 1991; Bicho et al. 2011; Bicho et al. 2015; Andrade et al. 2015) - ao que se junta a notícia do «acampamento» do Neolítico antigo de ORZ-1 (Gonçalves 1983-84b) e a divulgação recente do sítio de igual cronologia de Cortiçóis (Cardoso et al. 2013). Será de referir também, um pouco mais afastados mais ainda incluídos na mesma unidade regional, o sítio do Neolítico antigo cardial de Casas Novas (Gonçalves 2009; Gonçalves - Sousa 2015) ou o sítio de Monte da Foz 1 (Neves 2010).

Ocupações relativas ao Neolítico final e Calcolítico eram também conhecidas nesta unidade regional genérica, nomeadamente os sítios de Cabeço do Pé da Erra (Gonçalves 1982, 1983-84a; Gonçalves Sousa 2014), Monte da Quinta 2 (Valera et al. 2007) e Cabeço da Bruxa (Kalb - Höck 1981-82) - sem que tal fosse representado, para além do contexto funerário de Martim Afonso, na área de Muge.

Com a revisão e sintetização dos materiais arqueológicos recolhidos por Gonçalo Lopes no âmbito da sua dissertação de Licenciatura, constatouse que efectivamente se reconhecia na área de Muge uma ocupação relativamente consistente por parte das comunidades do Neolítico final e Calcolítico, reforçando-se igualmente o conhecimento referente às ocupações das comunidades do Neolítico antigo e médio (Neves 2010; Neves et al. 2008; Neves et al. 2015; Andrade et al. 2015).

Reconhecem-se assim, numa área relativamente circunscrita e no âmbito cronológico deste trabalho: ocupações relativas ao Neolítico final/Calcolítico, tais como Porto do Sabugueiro (loci Alqueve 1 e 2), Forno do Tijolo 2, Olival de Vasques, Sobreiro do Neto, Adua 1, Vale de Lobos 1, Vale de Lobos 4 e Sobral do Martim Afonso; ocupações relativas ao Calcolítico final, tais como Porto do Sabugueiro, Forno do Tijolo 2, Quinta do Dias, Vale de Lobos 4 e Sobral do Martim Afonso.

Neste contexto, o interesse relativo do sítio do Sobral do Martim Afonso deve-se a três factores particulares: 1) à aparente coincidência entre um lugar habitacional e um lugar de enterramento, reunindo-se num mesmo local espaços dos vivos e espaços dos mortos; 2) ao carácter «culturalmente megalítico» do contexto funerário aí identificado, numa área onde não se conhecem antas nem onde, devido à inexistência efectiva de suportes 
construtivos adequados no substrato geológico local, estas poderiam ter virtualmente existido; 3 ) à sua posição geográfica, em área de charneira entre o Alentejo e a Península de Lisboa.

É bem conhecida, no Sudoeste peninsular, a ocorrência de áreas funerárias anexas a povoados (e mesmo no interior destes), referindo-se contudo ao caso de aparentes grandes centros populacionais como Perdigões (Lago et al. 1998; Valera et al. 2000), La Pijotilla (Hurtado 1987), Porto Torrão (Valera 2010; Valera et al. 2014), Alcalar (Morán - Parreira 2007) ou Valencina de la Concepción (Mejías-García et al. 2015). Dificilmente poderemos propor que, no estado actual dos conhecimentos, o sítio Sobral do Martim Afonso configure a existência de um grande centro populacional, mesmo tendo em conta a quantidade e variedade do espólio em relação a outros sítios imediatos. Este, com efeito, não é quantitativamente significativo, nem o é a sua área de dispersão, para o propor como um grande povoado estável. Nem mesmo associando os sítios contíguos de Sobreiro do Neto e Adua 1, contabilizando cerca de $4 \mathrm{~km} 2$ de dispersão (não necessariamente contínua) de espólio arqueológico, esta hipótese poderá ser defensável.

Seja como for, tanto o contexto habitacional como o contexto funerário estão arqueograficamente comprovados, assim como a aparente associação entre ambos. O que há a destacar é precisamente a presença de um contexto sepulcral «culturalmente megalítico», numa área onde não se conhecem monumentos megalíticos nem os suportes geológicos necessários à sua construção - recolhendo, nesta unidade regional, paralelos directos (e com a ressalva devida a algumas notórias divergências entre ambos contextos, como se verá abaixo) no sítio de Monte da Barca (Vicente et al. 1971; Gonçalves 2011), para além do misterioso caso de Vale de Cavalos...

Noque diz respeito aos artefactos propriamente ditos (fundamento da asserção do «carácter megalítico» deste contexto), várias observações deverão se consideradas.

Os recipientes cerâmicos, tratando-se exemplares de forma simples, de pequena dimensão, são comuns em contextos funerários de finais do $4^{\circ} \mathrm{e}$ do $3^{\circ}$ milénio a.n.e., pelo que não oferecem grandes motivos de comentário - referindo-se apenas a sua potencial produção local (de acordo com as características minerais dos componentes não plásticos).

A alabarda da sepultura do Sobral do Martim Afonso apresenta características particulares que a permitem enquadrar numa categoria específica: as alabardas de tipo Casa da Moura, distinguíveis precisamente por apresentarem base triangular com polimento nas áreas ventrais (segundo o que foi definido em Ferreira 1970).

Paralelos directos poderão ser assim encontrados nas grutas do Furadouro da Amoreira (Ferreira 1970), Casa da Moura (Carreira - Cardoso 2001/2002), Cova da Moura (Spindler 1981), Alcobaça (Ferreira 1970), Senhora da Luz 2 (Cardoso - Ferreira Carreira 1996) e Cabeço de Turquel (Ferreira 1970).

Outras variantes (sem polimento ventral mas igualmente com base triangular) poderão ser encontradas em Cabeço da Arruda 1 (Leisner 1965: Taf. 5), Aljezur (Leisner 1965: Taf. 131), Rabuje 3 (informação pessoal de Rui Boaventura), Brotas (Leisner - Leisner 1959: Taf. 28), Comenda da Igreja (Leisner - Leisner 1959: Taf. 25), Granja de Céspedes (Almagro Basch 1961-62) ou Cueva de la Mora (Leisner - Leisner 1959: Taf. 53).

Trata-se de um tipo pouco comum de alabardas, sendo de notar que a larga maioria provem de contextos funerários estremenhos, com semelhanças (tanto a nível de morfologia como das características da matéria-prima) com a alabarda da «sepultura» do Sobral do Martim Afonso.

O conjunto das lâminas apresenta igualmente algumas particularidades interessantes, correspondendo a produções especializadas obedecendo a especificidades técnicas (Gallet 1998; López de Pablo et al. 2006; Morgado - Pelegrin 2012). Aparentemente, poderão provir de um número restrito de blocos: especialmente as lâminas MNA 997.73.10 a 14, apresentando exactamente as mesmas características petrográficas, poderão ter sido extraídas de um mesmo núcleo. Mais do que resultado de talhe imediato local para deposição funerária a partir de um único bloco, tal facto poderá apenas indicar que estes elementos formariam um «pacote» único (tendo sido adquiridos deste modo), produzido e organizado num mesmo momento no contexto de expectativas de intercâmbio.

A produção e deposição ritual de grandes lâminas de sílex em contextos funerários são relativamente comuns durante o $3^{\circ}$ milénio a.n.e. no Sudoeste peninsular (Morgado Rodríguez et al. 2009). No contexto sepulcral de Pragais, por exemplo, foram recolhidas mais de cinco dezenas de lâminas de sílex depositadas juntas (acompanhadas por alabardas, punhais e uma placa de xisto gravada), de várias fases de debitagem e provenientes possivelmente de um número restrito de blocos (Sousa 2004). Da mesma maneira, no Sepulcro 3 dos Perdigões foram 
identificadas mais de duas dezenas de lâminas de sílex também depositadas juntas, representando igualmente várias fases de debitagem (Valera et al. 2007: 55, 66 - Fig. 6). E isto para não falar também dos espantosos conjuntos de Alcalar (Veiga 1889) e Olival da Pega 2b (Gonçalves 1999)...

Uma análise macroscópica do sílex usado tanto na alabarda como nas lâminas permite evidenciar, para além de óxidos de ferro, escassos elementos micro e macro-quártzicos, sem serem perceptíveis quaisquer vestígios bioclásticos preservados, sendo a textura mudstone uma característica homogénea do conjunto. Aparentemente, apresenta características típicas das silicificações cenomanianas da área do Maciço Calcário Estremenho (cf. Matias 2012; Aubry et al. 2014), sendo obviamente necessária outra escala de análise para confirmar esta hipótese.

O sítio do Sobral do Martim Afonso poderá assim encontrar-se numa área intermédia do eixo de circulação do sílex estremenho para o Alentejo. Tal hipótese poderá encontrar evidência precisamente na comparação entre a matéria-prima usada na alabarda da «sepultura» do Sobral do Martim Afonso e a usada na alabarda proveniente da anta de Brissos 6, localizada já na área alentejana. Com efeito, apesar das divergências morfológicas entre ambas peças, as características petrográficas da matériaprima são exactamente as mesmas - podendo ser, mesmo que a nível teórico, proposta a mesma área de aprovisionamento, curiosamente coincidente com conhecidas oficinas de talhe calcolíticas direccionadas à produção de grandes lâminas e pontas bifaciais (Zilhão 1994, 1997; Forenbaher 1999; Andrade et al. 2014).

Em relação ao báculo da «sepultura» do Sobral do Martim Afonso, este opõe-se, em termos decorativos, aos seus congéneres mais correntes cuja decoração se compõem basicamente por faixas paralelas (decoração listada) seguindo o eixo da peça, rematadas junto ao bordo externo por uma banda de triângulos preenchidos com o vértice tanto orientado para o interior como para o exterior. Contudo, não se trata de um tipo incomum, com paralelos decorativos directos nos báculos de Alcogulo 3 (Leisner - Leisner 1959: Taf. 3), Marquesa (Leisner - Leisner 1959: Taf. 4), Couto de Enchares (Isidoro 1965-66), Boudanha (Leisner - Leisner 1959: Taf. 8) ou Loba 2 (Gonçalves et al. 2005), sendo de referir igualmente as variantes apresentadas pelos exemplares notáveis da Lapa da Galinha (Gonçalves et al. 2014), Monte da Barca (Gonçalves 2011) ou Herdade das Antas (Leisner Leisner 1959: Taf. 29).

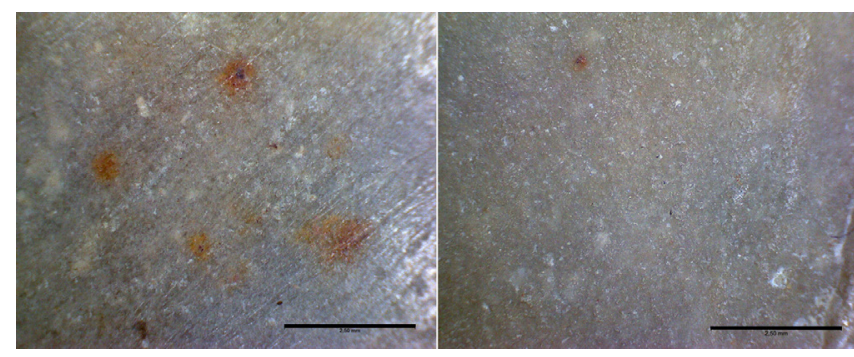

Fig. 30 - Comparação microscópica (x50) dos sílices utilizados na albarda MNA 997.73.6 recolhida na «sepultura» do Sobral do Martim Afonso e na alabarda MNA 995.45.61 recolhida na anta de Brissos 6. A escala corresponde a $2,5 \mathrm{~mm}$.

Sobre a inumação propriamente dita, caso os restos osteológicos disponíveis pertençam efectivamente a um mesmo indivíduo, o volume relativamente restrito do espólio poderá indicar que se trata de um único enterramento singular. Com efeito, este "pacote votivo», sendo composto por uma alabarda, oito lâminas, três (ou quatro) recipientes e um báculo, facilmente se poderá atribuir a uma inumação individual - tendo em conta outros paralelos datáveis de finais do $4^{\circ}$ e do $3^{\circ}$ milénio a.n.e.

No entanto, várias questões serão de referir nesta assumpção: apesar de aparentemente poderem pertencer ao mesmo indivíduo, esta leitura está longe de se assegurar com rigor (sendo obviamente necessária outra escala de análise); não há certezas de ser este o único espólio recolhido na «sepultura» de Martim Afonso, podendo outros componentes não terem sido identificados ou recolhidos, ou mesmo terem sido extraviados.

Contudo, a descrição avançada por F. Pereira da Costa (Simões 1878: 101) permite supor que se trataria efectivamente de uma deposição individual, seja tanto pela indicação precisa da identificação de "ossos de um esqueleto» (sublinhado do signatário) como pela caracterização do contexto estrutural propriamente dito. Com efeito, é descrito como uma "sepultura [...] de tres lages compridas e duas estreitas nas extremidades, e tinha um capeamento de lages pequenas» (Simões 1878: 101). Não se trata propriamente de um monumento megalítico típico, estruturas bem conhecidas por F. Pereira da Costa, principalmente depois dos seus trabalhos na área alentejana (Costa 1868), podendo corresponder a um pequeno sepulcro individual de tendência «cistóide» possivelmente «implantado» em fossa escavada no substrato (tendo em conta o contexto geológico em que se encontra).

Como dito, encontra paralelos, nesta área 


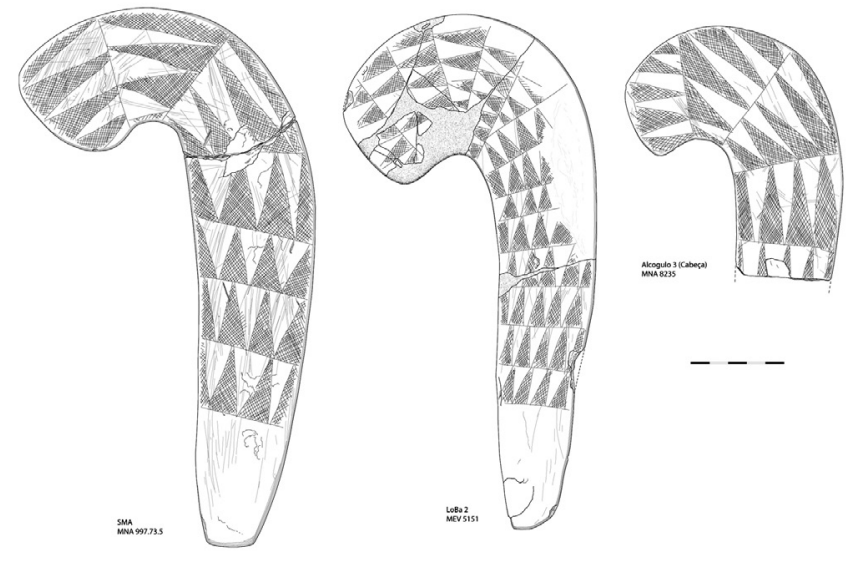

Fig. 31 - Comparação entre o báculo recolhido na «sepultura» do Sobral do Martim Afonso (MNA 997.73.5) e os báculos recolhidos nas antas de Loba 2 (ME 5151) e Alcogulo 3 (MNA 8235).

regional, no sítio de Monte da Barca. No entanto, não foi reconhecido neste sítio qualquer tipo de estruturação do espaço funerário. Da mesma maneira, as cerca de três dezenas de placas de xisto gravadas (e uns quantos báculos) recolhidas em Monte da Barca (Gonçalves 2011) permitem supor um valor idêntico para o número mínimo de indivíduos aí depositados (partindo do princípio que uma placa de xisto gravada acompanharia uma inumação específica, salvaguardando igualmente aquelas que poderiam não ser acompanhadas por estes artefactos ou acompanhadas exclusivamente pelos báculos). Como se denota, trata-se de um contexto sepulcral indiscutivelmente colectivo, ao contrário do que parece suceder no sítio do Sobral do Martim Afonso.

Seja como for, estas ocorrências vêm confirmar a existência de contextos funerário «megalíticos» em área extrínsecas às grandes manchas de dispersão de monumentos megalíticos conhecidas. Serão assim nestas áreas os enterramentos realizados em fossa (ou outro qualquer tipo de estruturas subtérreas)? As prospecções realizadas recentemente no âmbito do projecto ANSOR (dirigido por Victor S. Gonçalves e Ana Catarina Sousa) não permitiram clarificar esta questão. No entanto, estas serão «estruturas» dificilmente detectáveis à superfície, pelo que a sua não identificação não significa necessariamente a sua inexistência. Na verdade, a presença comprovada de sítios de habitat nestas áreas permite supor a óbvia existência de espaços funerários correlativos.

As características particulares destes lugares de enterramento, principalmente a nível da sua situação geológica, vêm renovar a questão já levantada por C. D. Oliveira e J. Oliveira (2000) a respeitos dos aparentes «vazios megalíticos» na área do Alto Alentejo, nomeadamente nas áreas correspondentes ao enchimento terciário do Tejo. Assim, este aparente vazio poderá ser tendencioso, dado que os sepulcros poderão efectivamente referir-se a outro tipo de manifestações funerárias, dificilmente detectáveis actualmente à superfície. As ocorrências de Monte da Barca e Sobral do Martim Afonso reforçam essa ideia.

É desta maneira possível que a mancha megalítica (no sentido arquitectónico do termo) esteja dependente de condicionantes geológicas, sendo a transição entre os substratos hercínicos e o enchimento terciário do Tejo assumida como limite ocidental dos grupos megalíticos alto e centroalentejanos.

Em relação ao esquema de povoamento em que o sítio do Sobral do Martim Afonso se incluiria, registam-senasuaenvolvência(ecomoreferidoacima) vários sítios crono-culturalmente coevos, esboçando cerca de $20 \mathrm{~km} 2$ de área ocupada durante o Neolítico final e Calcolítico. Apesar de a ocupação registada no contexto habitacional do sítio do Sobral do Martim Afonso poder recuar até aos últimos séculos do $4^{\circ}$ milénio a.n.e. (pela presença de taças carenadas), os restantes sítios - Porto do Sabugueiro (loci Alqueve 1 e 2), Forno do Tijolo 2, Olival de Vasques, Sobreiro do Neto, Adua 1, Vale de Lobos 1 e Vale de Lobos 4 - parecem corresponder a ocupações exclusivas do $3^{\circ}$ milénio a.n.e. Dever-se-á ter em conta, contudo, que estas hipóteses se encontram baseadas apenas em recolhas de superfície - evidenciando assim a sua falibilidade relativa (podendo outros elementos ser fornecidos por trabalhos de escavação). No entanto, esta assumpção cronológica é ratificada pelos dados fornecidos por sítios coevos já escavados nesta unidade regional, como Monte da Quinta 2 (Valera et al. 2007), Cabeço do Pé da Erra (Gonçalves 1982, 1983-84a; Gonçalves - Sousa 2014) e Cabeço da Bruxa (Kalb - Höck 1981-82; Parreira 1987).

Com efeito, tendo em conta os dados fornecidos por sítios como Olival de Vasques e Adua 1 (aqueles que, para além do Sobral do Martim Afonso, têm maior volume de informação disponível), apenas poderão ser sugeridas para estes sítios ocupações relativas ao $3^{\circ}$ milénio a.n.e. $A$ presença de taças de bordo espessado, esféricos de bordo exvertido, «ídolos de cornos», artefactos de pedra polida de secção rectangular e lâminas espessas retocadas indicam ocupações eminentemente calcolíticas. O sílex utilizado nestes sítios para os artefactos de 

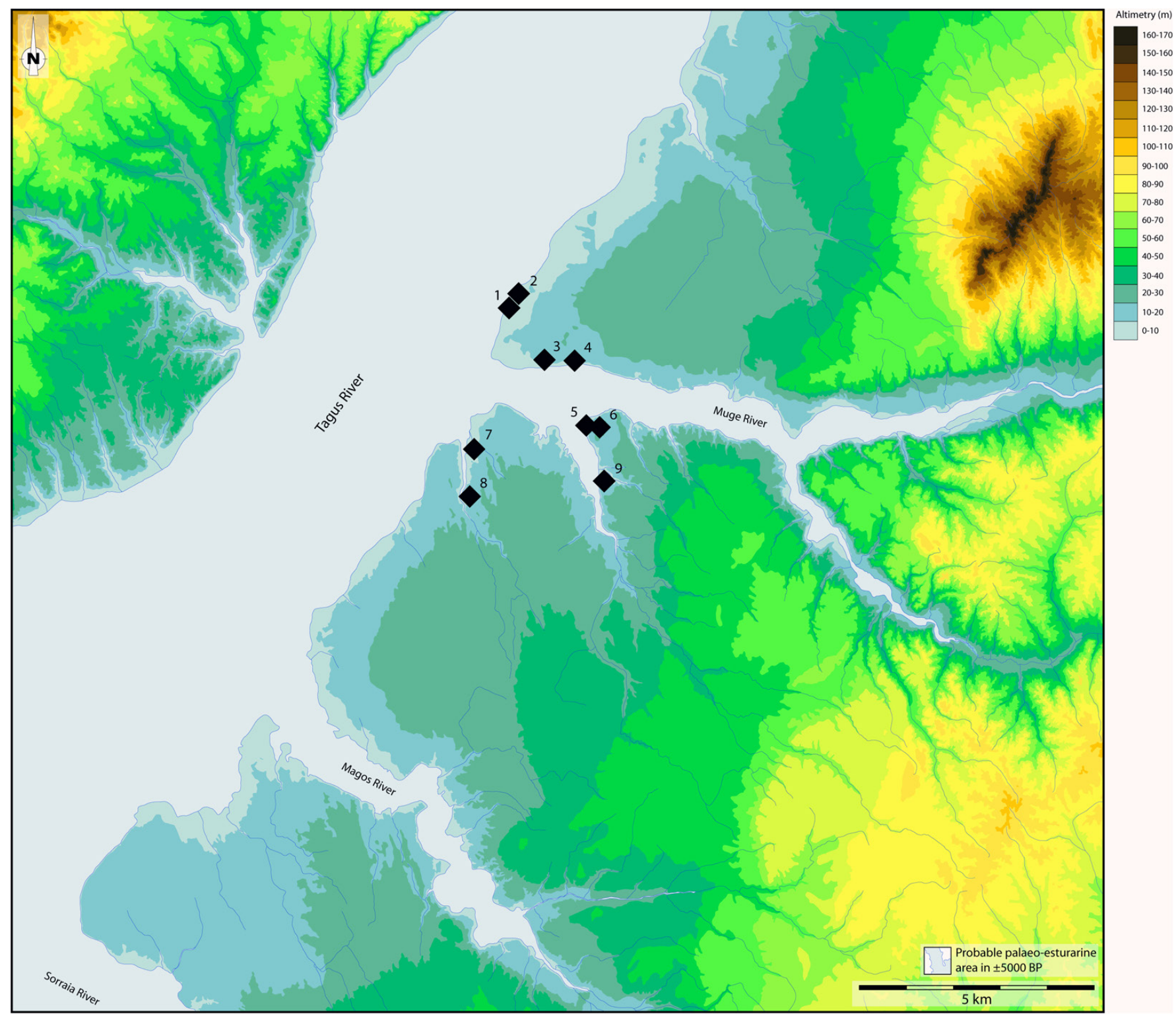

Fig. 32 - Sítios do Neolítico final/Calcolítico da área de Muge. 1: Alqueve 1 (Porto Sabugueiro); 2: Alqueve 2 (Porto Sabugueiro); 3: Forno do Tijolo 2; 4: Olival de Vasques; 5: Sobreiro do Neto; 6: Adua 1; 7: Vale de Lobos 1; 8: Vale de Lobos 4; 9: Sobral do Martim Afonso.

pedra lascada (assim como para aqueles do Sobral do Martim Afonso, exceptuando a lâmina SMA.94.1) apresentam genericamenteas mesmas características petrográficas que as apontadas para os elementos líticos do «contexto funerário» do Sobral do Martim Afonso - reflectindo aparentemente as mesmas áreas de aprovisionamento.

O sítio de Porto do Sabugueiro (disperso entre os loci Alqueve 1 e 2) revela-se igualmente como um caso curioso. No conjunto do espólio conhecido, para além dos fragmentos cerâmicos (potencialmente incluindo campaniforme) identificados já na área de afectação do curso do Tejo e dos artefactos de pedra lascada e pedra polida (apresentados em Pimenta et al. 2014), destacam-se os fragmentos de placas de xisto gravadas, um «cossoiro» cerâmico e um fragmento de artefacto de xisto com perfuração.

Em relação às placas de xisto gravadas, estas referem-se a dois fragmentos (PS.94.1 e 2) - apresentando um deles bandas de triângulos preenchidos com o vértice para cima e o outro traços verticais incaracterísticos (fragmento de «esboço»?). Tal ocorrência não sugere necessariamente que estejamos perante um contexto funerário (como o registado em Martim Afonso), sendo sobremaneiramente conhecidas as recolhas de placas 


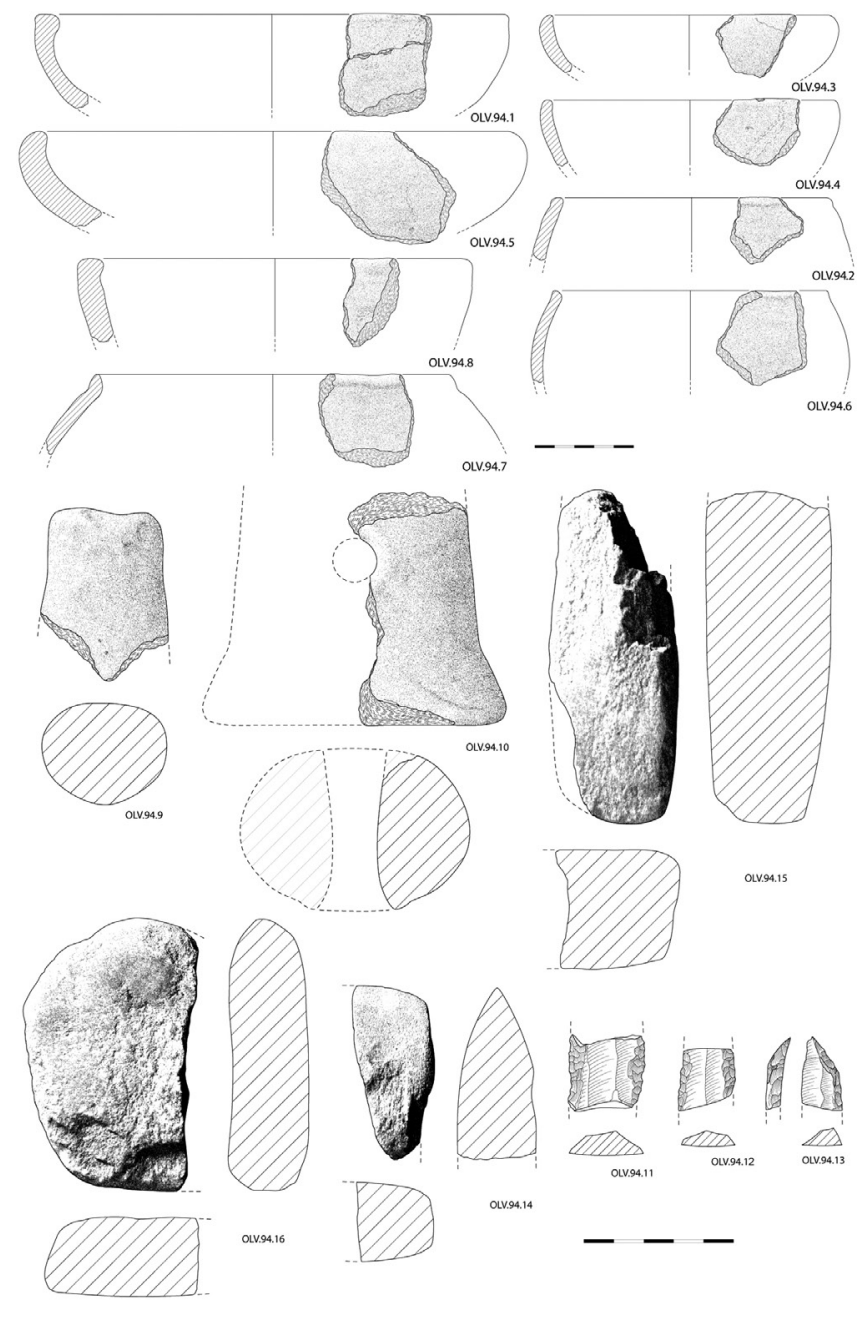

Fig. 33 - Exemplos do espólio recolhido no sítio calcolítico de Olival de Vasques: recipientes cerâmicos, «ídolos de cornos» (OLV.94.9 e OLV.94.10), artefactos de pedra polida (OLV.94.15, OLV.94.16 e OLV.94.14) e artefactos de pedra lascada (OLV.94.11, OLV.94.12 e OLV.94.13). Recipientes cerâmicos à escala 1:3; restante espólio à escala 1:2.

de xisto gravadas (ou seus fragmentos) em contextos habitacionais - sem que tal indique utilizações funerárias do espaço (Andrade et al., 2015, 2016). Refira-se ainda que, no mesmo contexto regional, um possível atelier de placas de xisto gravadas foi já identificado, apesar da ausência de suportes no substrato geológico local, referindo-se ao sítio de Cabeço do Pé da Erra, com uma datação directa para este contexto específico balizada entre 2911-2640

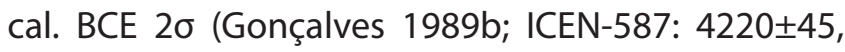
recalibrada em 2013).

A peça interpretada como "cossoiro» referese a um artefacto cerâmico de forma esférica com perfuração cilíndrica (PSAB/08-1781), distinguindose dos cossoiros da Idade do Ferro aqui recolhidos

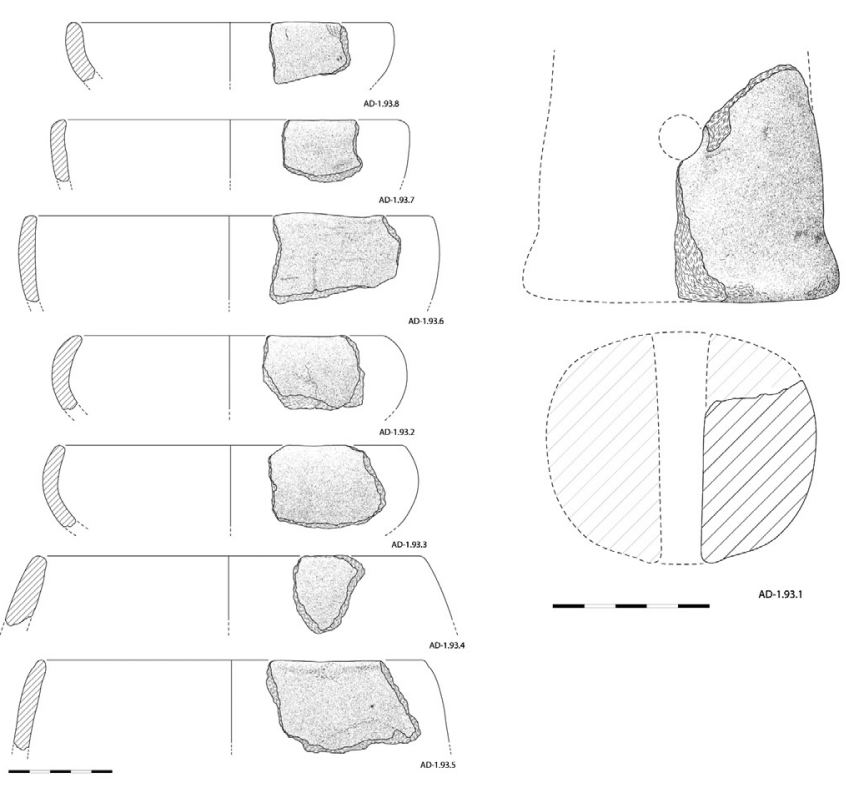

Fig. 34 - Exemplo do espólio recolhido no sítio calcolítico de Adua 1: recipientes cerâmicos e «ídolos de cornos» (AD-1.93.1). Recipientes cerâmicos à escala 1:3; «ídolo de cornos» à escala 1:2.

pela forma e pela pasta (menos compacta e mais heterogénea, com cozedura redutora e elementos não plásticos compostos por quartzos sub-rolados e feldspatos). É semelhante aos artefactos recolhidos em Cabezo Juré, interpretados como instrumentos utilizados na produção têxtil (cf. Nocete Calvo 2004) Contudo, exemplares semelhantes recolhidos no povoado calcolítico do Outeiro de São Mamede são interpretados como contas de colar cerâmicas (Cardoso - Carreira 2003: 144).

A última peça mencionada refere-se ao fragmento de um artefacto alongado de xisto sumariamente polido, com perfuração (PSAB/08979). Poderá corresponder a um pendente ou a um pequeno «braçal de arqueiro» - estando fracturado, não é possível definir com rigor a sua morfologia. No entanto, a observação de potenciais cerâmicas campaniformes na área do Porto do Sabugueiro poderá concorrer para a defesa da segunda hipótese.

Seja como for, tratam-se de dados desarticulados que não possibilitam leituras rigorosas. As ocupações da Idade do Ferro e do período romano poderão ter obliterado as ocupações antecedentes - não sendo estas estratigraficamente reconhecidas (informação pessoal de Ana Margarida Arruda).

Em relação a Vale de Lobos 1 e no conjunto do espólio recolhido, merece destaque um polidor decorado em micaxisto. Exemplares deste género (e igualmente decorados) são conhecidos em contextos 


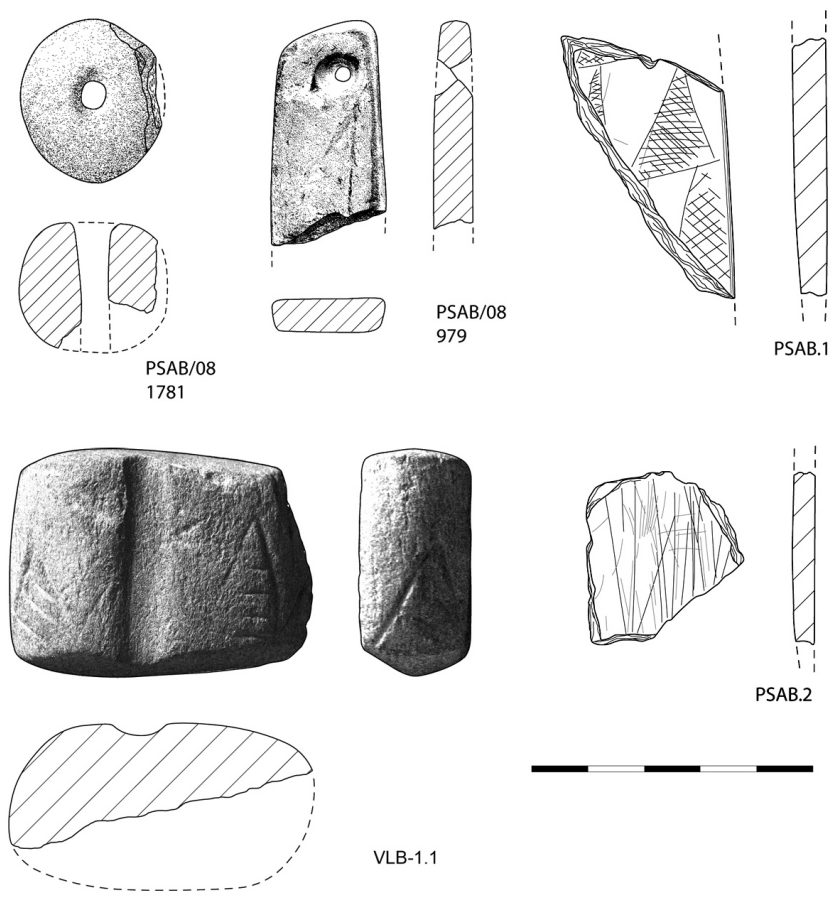

Fig. 35 - Espólio recolhido no sítio de Porto do Sabugueiro e Vale de Lobos 1: «cossoiro» (PSAB/08-1781); «braçal de arqueiro» ou pendente de xisto (PSAB/08-979); fragmento de placa de xisto gravada (PS.94.2); fragmento de placa de xisto com gravação caótica (PSAB.93.1); polidor de micaxisto decorado (VLB-1.94.1).

mais recuados no Sudoeste peninsular, como no sítio do Neolítico antigo de Valada do Mato (Diniz 2007; Diniz - Vieira 2007). No entanto, a larga maioria das peças conhecidas reporta-se a contextos já do Neolítico final e Calcolítico - curiosamente incluindo monumentos megalíticos, como Couto de Biscaia 1, Tapada da Laje das Peles, Penedos de São Miguel, Arneirinhos 1, Xarez 1, San Bartolomé de la Torre ou Zafra 2 (Isidoro 1970, 1971; Gonçalves 2013; Andrade 2009; Cerdán Márquez et al. 1952; Bueno Ramírez 1988). Serão de referir igualmente os exemplares decorados, para além de alguns dos monumentos anteriormente referidos, provenientes de La Pijotilla, Serra da Preguiça, Claros Montes, Vale Guardez 1 e Casa da Moura (Hurtado 1980; Soares - Real 2005; Calado 2001; Boaventura - Mataloto 2011; Carreira Cardoso 2001-2002).

Esta assumpção cronológica é igualmente ratificada pelo motivo decorativo específico do exemplar deVale de Lobos 1 (triângulos preenchidos), fazendo-o equiparar-se, pelo menos teoricamente e a nível cultural, às placas de xisto gravadas não sendo motivo exclusivo destes artefactos, surgindo igualmente em outros artefactos crono- culturalmente coevos, como as enxós votivas de calcário da Península de Lisboa ou os recipientes cerâmicos com decoração simbólica de todo o Sudoeste peninsular.

Em relação à sua função, os exemplares decorados calcolíticos são genericamente assumidos como ídolos (por exemplo, La Pijotilla, Serra da Preguiça ou San Bartolomé de la Torre) - fazendoos corresponder (no conjunto entre o sulco e a decoração associada) à representação de «una vulva femenina [não se percebendo que outro tipo de vulva poderá haver, sendo dificilmente admissível a existência de uma vulva masculina], tema frecuente en los ciclos agrarios en los que la fecundidad de seres y plantas es parte integrante del complejo de ideas mágico-religiosas» (Almagro Basch et al. 1975: 190).

Interpretação mais prosaica é avançada porV.S. Gonçalves a respeito dos exemplares (não decorados) de Sala \#1 e Xarez 1 (Gonçalves 1987, 2013), sendo aqui assumidos como polidores - potencialmente de contas de colar, segundo a interpretação avançada para o exemplar de Sala \#1.

Para exemplos cronológica e geograficamente mais distantes (do Brommiense dinamarquês, do Sauveterrense franco-italiano e do Natufiense ou do Khiamense-Mureybetense levantinos), artefactos morfologicamente análogos são interpretados como «arrow shaft straighteners» (Riede 2012; Plisson et al. 2008; Christensen - Valla 1999; BarYosef 1998; Dubreuil 2004) - embora quanto aos exemplares decorados do Khiamense-Mureybetense, distinguíveis daqueles do Natufiense precisamente pela decoração, se proponha um carácter mais simbólico (Cauvin 1997).

Seja como for, o facto de se tratarem hipoteticamente de objectos funcionais (no sentido exclusivamente material do termo) não é invalidado pela circunstância de possuírem elementos decorativos mágico-simbólicos. Lembremos, neste sentido, os elementos de tear de Vila Nova de São Pedro (Arnaud 2013), entre outros exemplos arqueográficos...

Contudo, admite-se igualmente a sua representação enquanto objectos votivos. À guisa de curiosidade, refira-se que artefactos semelhantes (alguns com decorações idênticas aos do Sudoeste peninsular) são encontrados em contextos funerários da cultura Chumash da "Late Prehistory» californiana, sendo avaliados não como «arrow shaft straighteners» mas como a representação destes - no quadro da reinterpretação que materializa o 


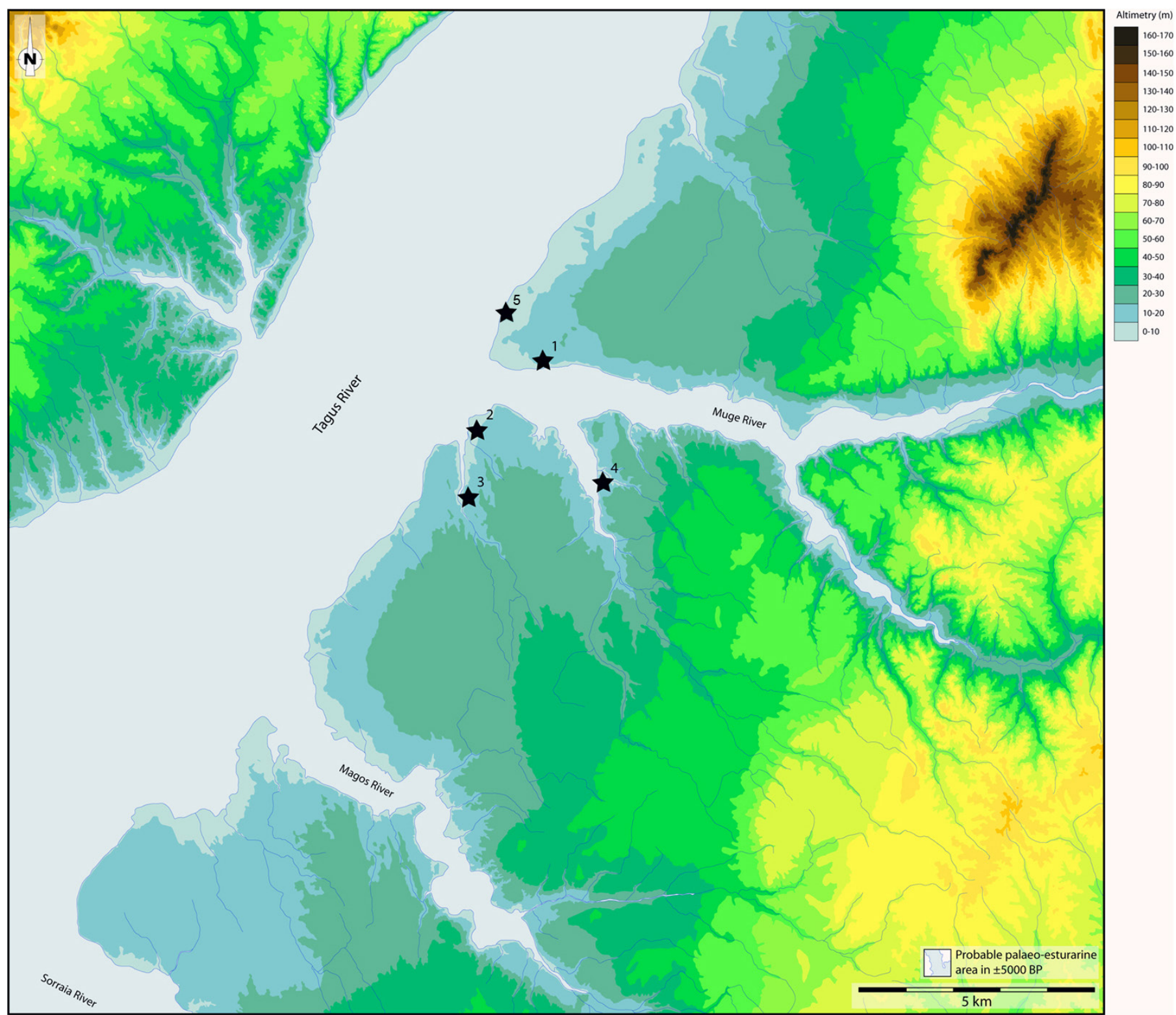

Fig. 36 - Sítios do Calcolítico final da área de Muge. 1: Forno do Tijolo 2; 2: Quinta do Dias; 3: Vale de Lobos 4; 4: Sobral do Martim Afonso; 5: Porto do Sabugueiro.

hipotético processo de sexualização-sacralização de instrumentos quotidianos (Koerper et al. 2004).

A ocorrência de elementos campaniformes em alguns destes sítios permite equacionar um continuum de utilização desta área durante todo o $3^{\circ}$ milénio a.n.e., tendo sido identificadas cerâmicas ou artefactos campaniformes, para além de no Sobral do Martim Afonso, em sítios como Porto do Sabugueiro, Forno do Tijolo 2, Quinta do Dias e Vale de Lobos 4 - referindo-se genericamente a tipos campaniformes tardios, já do último terço do $3^{\circ}$ milénio a.n.e. Principal destaque merece o fragmento recolhido em Vale de Lobos 4, correspondendo a uma caçoila muito aberta de ombro marcado com decoração incisa aplicada no fundo. A sua óbvia «inspiração» nos modelos de Ciempozuelos (cf. Harrison 1977) revela a influência, mais do que estremenha, de grupos campaniformes mais interiores. Também merece referência o «braçal de arqueiro» recolhido na Quinta do Dias (e talvez também em Porto do Sabugueiro), sendo elementos usualmente reservados a contextos funerários (não havendo outros elementos disponíveis para confirmar esta hipótese).

Este pequeno conjunto de sítios campaniformes não surge contudo isolado nesta unidade regional, surgindo possivelmente associado a sítios como 

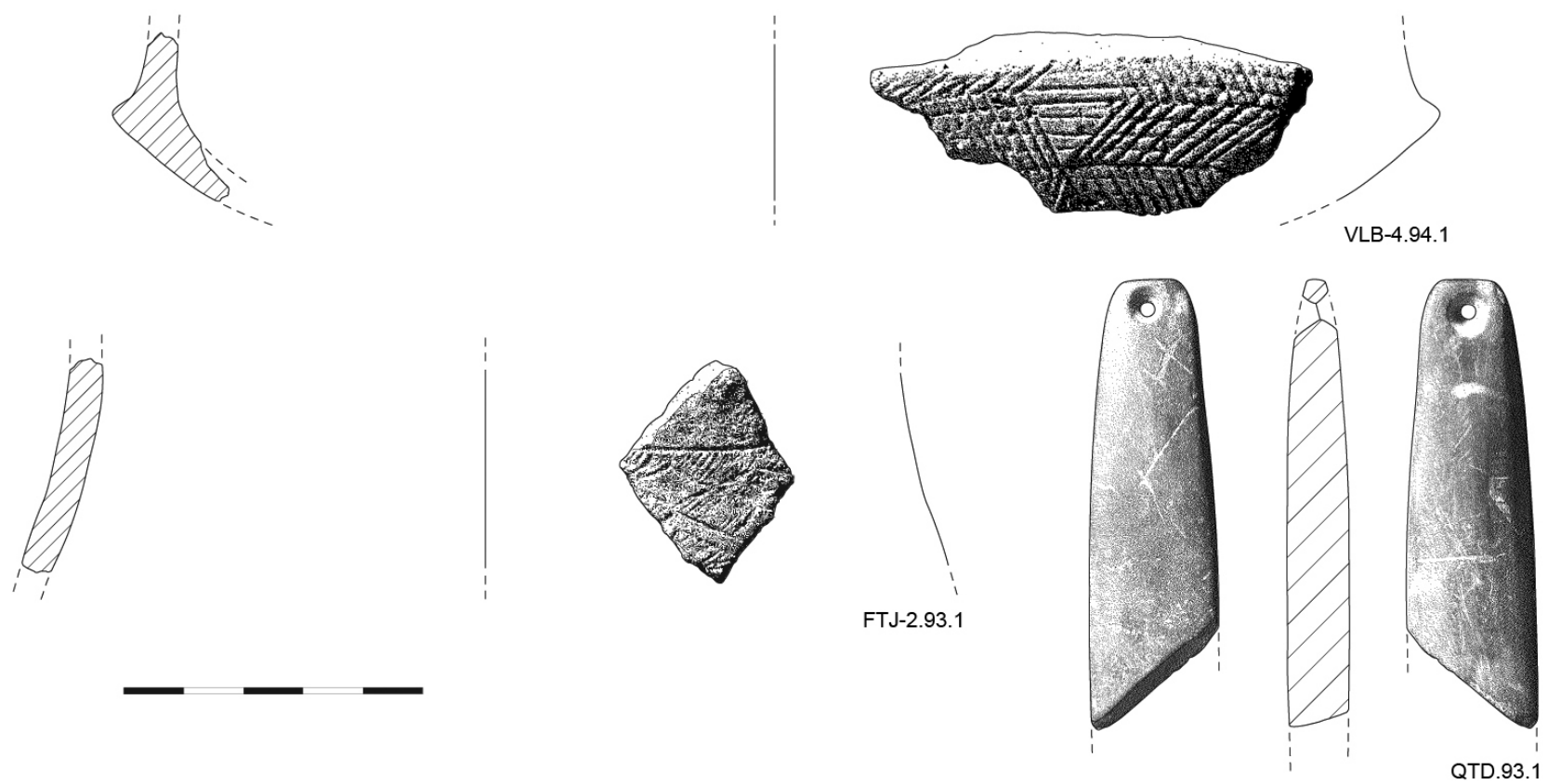

Fig. 37 - Espólio campaniforme recolhido nos sítios de Vale de Lobos 4, Forno do Tijolo 2 e Quinta do Dias: caçoila com decoração incisa (VLB-4.94.1); vaso com decoração incisa (FTJ-2.93.1); «braçal de arqueiro» de xisto (QTD.93.1).

Casas Novas (Gonçalves 2009), Barranco do Farinheiro 2 (Gonçalves - Sousa 2014; Gonçalves et al. no prelo), Cabeço da Bruxa (Kalb - Höck 1981-82; Parreira 1987), Alto dos Cacos (Pimenta et al. 2012) ou Riba-Rio já na margem oposta do Tejo (Pereira 2005).

A proximidade (espacial e crono-cultural) entre os diversos sítios identificados na área de Muge (durante todas as suas etapas de ocupação) poderia sugerir que os mesmos correspondam a uma única realidade, podendo esta ser interpretada de acordo com duas leituras explicativas: 1) vários núcleos ocupados simultaneamente, configurando uma vasta área assentamento com dispersão horizontal; 2) vários núcleos ocupados intercaladamente num mesmo contexto crono-cultural, em que uma comunidade se instala sazonalmente na mesma área mas não necessariamente no mesmo local.

Nesta leitura estruturalista do espaço, e consequentemente dos padrões de assentamento destas comunidades, não se poderá ignorar as características próprias desta unidade regional. $\mathrm{Na}$ verdade, os sítios aqui identificados mostram óbvias divergências com os sítios calcolíticos registados na margem oposta do Tejo (cf. por exemplo Sousa 2010), com especial ênfase para os sítios mais próximos ao paleo-estuário, como Moita da Ladra, Pedra do Ouro, Ota e Vila Nova de São Pedro.

Com efeito, situam-se sensivelmente a meio caminho entre estes sítios estremenhos e os sítios mais «avançados» do Calcolítico alentejano, como Serra 1 (Pontis 1999), Castelo de Pavia (Rocha 1999) e Cabeço da Velada (recolhas de Gil Miguéis de Andrade, em exposição no Museu de Montemoro-Novo), sendo evidência de um eixo de circulação ligando ambas áreas e desenvolvido possivelmente ao longo dos cursos de água subsidiários do Tejo, como o Sorraia.

De facto, a ampla planície aluvionar que constitui o vale deste curso de água (e cursos de água paralelos, enquadrada pelos relevos mio-pliocénico que a cingem a Norte, terá funcionado como uma extensa área de circulação, sem qualquer constrição orográfica, entre o Alentejo e a Estremadura funcionando a Charneca do Ribatejo (onde se enquadra a área de Muge) como plataforma de ligação entre aquelas regiões.

Com efeito, a confluência com o Sorraia das Ribeiras de Sor e Seda por um lado, e das Ribeiras de Tera e Raia por outro, funcionaria como junção (ou disjunção) de dois dos «sub-grupos megalíticos» alentejanos: o do Alto Alentejo (triângulo Crato-NisaCáceres) e o do Alentejo Central (linha MontemorÉvora-Reguengos).

Curiosamente, se entendermos o início do fenómeno megalítico alentejano (enraizado no Neolítico médio) como consequência lógica 
do «avanço» para o interior das comunidades estremenhas do Neolítico antigo tardio, deverse-á notar a singular concentração das «primeiras arquitecturas» megalíticas nas áreas de Coruche/ Montemor, Montargil e Mora/Avis, na charneira entre os terrenos hercínicos e o enchimento terciário do Tejo.

Desta maneira, as áreas dos Foros de Salvaterra e de Almeirim poderão ter sido usadas como áreas de staging posts, servindo as áreas da Charneca do Ribatejo como espaços de circulação. No entanto, a existência de sítios de enterramento, de carácter individual ou colectivo, permite supor um povoamento mais estável do que aqueleque resultaria de um esquema restrito de tipo «acampamento».

Porém, sobre os padrões de subsistência e as estratégias de exploração de recursos disponíveis destas comunidades, nada de concreto se poderá referir devido à carência efectiva de dados. Encontrando-se todavia no mesmo contexto ecológico que outros sítios de referência, como Monte da Quinta 2 e Cabeço do Pé da Erra, as mesmas actividades de subsistência poderiam ser propostas.

Monte da Quinta 2, ocupado durante finais do $4^{\circ} \mathrm{e}$ inícios do $3^{\circ}$ milénio a.n.e. corresponde a um sítio especializado destinado à exploração do sal, embora outras actividades sejam de considerar - como a tecelagem, evidente pela recolha de elementos de tear (Valera et al. 2007). Já o Cabeço do Pé da Erra, ocupado desde o primeiro terço do $3^{\circ}$ milénio a.n.e. adiante, apresenta um carácter eminentemente agrícola, visível na recolha de elementos de mó, elementos de tear e queijeiras (Gonçalves - Sousa 2014).

De acordo com os dados disponíveis actualmente, dificilmente poderemos propor para os sítios da área de Muge a existência de uma componente agrícola relevante (não se considerando suficiente o elemento de mó recolhido no sítio do Sobral do Martim Afonso para confirmar esta hipótese). Por outro lado, uma actividade específica semelhante àquela registada em Monte da Quinta 2 poderá ser sugerida.

O fundo de recipiente troncocónico recolhido no sítio do Sobral do Martim Afonso poderá indicar, como referido, uma actividade particular, nomeadamente a produção de sal. Lembremos, neste sentido, que esta área seria caracterizada como um marisma salobre durante o Neolítico/ Calcolítico (Santos 2010), assim como que recipientes com características morfológicas idênticas foram registados em sítios também instalados na área do paleo-estuário do Tejo e vocacionados para a produção de sal, como o já referido Monte da Quinta 2 (Valera et al. 2007) ou Ponta da Passadeira (Soares 2013).

O facto de este vaso não ter fundo (e equacionou-se igualmente a hipótese de poder tratar-se de um bordo, não se reconhecendo forma semelhante nos catálogos cerâmicos calcolíticos), poderá referir-se apenas a uma especificidade técnica: poderia ter um fundo em madeira (ou noutro qualquer material perecível), removível para facilitar a remoção do «pão de sal» sem fracturar o recipiente e vedado com uma qualquer substância isolante, para evitar escorrências durante o fabrico da salmoura - devendo esta actividade ser realizada sem sujeitar o recipiente à acção directa do fogo (em «placas térmicas» compostas por seixos aquecidos, por exemplo).

Da mesma maneira, a presença de «ídolos de cornos» em praticamente todos os sítios calcolíticos aqui documentados poderia concorrer para a aferição desta hipótese (tendo em conta os dados de Ponta da Passadeira e Monte da Quinta 2), mas isso seria já tema para outro debate...

Seja como for, e dentro do seu contexto específico de estudo, a ocorrência do sítio do Sobral do Martim Afonso vem reforçar aquilo que já foi dito em outros locais (Andrade 2013; Andrade et al. 2010; Gonçalves et al. 2014): a existência de um efectivo eixo de circulação ligando a Estremadura ao Alentejo durante o Neolítico final e o Calcolítico.

Assim, durante este patamar cronológico, com a afirmação de redes de troca regulares entre o Alentejo e a Estremadura, esta área constitui-se como um espaço de conexão entre estes dois territórios culturalmente distintos, agindo as ocupações aqui reconhecidas como evidência directa e efectiva para a definição de diagramas de povoamento organizados.

Com efeito, a presença no sítio do Sobral do Martim Afonso de elementos culturalmente atribuíveis às comunidades estremenhas (como os copos canelados) a par de outros atribuíveis às comunidades alentejanas (como as taças de carena baixa e os pratos de bordo almendrado) permite aparentemente confirmar esta hipótese - fortalecida pela presença de sílex estremenho e de rochas anfibólicas alentejanas (curiosamente, um «blocolingote», intuitivo elemento de intercâmbio).

Tais relações estão igualmente sugeridas pelos sítios acima referidos de Monte da Quinta 2 e Cabeço do Pé da Erra. Às taças de carena baixa recolhidas no primeiro sítio contrapõem-se os elementos de tear 
rectangulares espessos (típicos da área estremenha); aos pratos de bordo almendrado recolhidos no segundo sítio contrapõem-se as cerâmicas com decoração «folha-de-acácia» características da Península de Lisboa.

Em áreas mais interiores, estas redes de intercâmbio materializam-se nas características de alguns elementos do espólio. Destaca-se por um lado a presença de cerâmicas com decoração «folhade-acácia» e lâminas ovóides de sílex no Cabeço da Velada ou as lâminas ovóides, o «ídolo de gola» e pontas de seta mitriformes recolhidas na Anta Grande da Comenda da Igreja (Leisner - Leisner 1959: Taf. 2527); por outro lado, será de referir as características tipicamente alto-alentejanas das placas votivas recolhidas nas grutas da Lapa da Galinha e Marmota (Gonçalves et al. 2014).

O estabelecimento destes eixos de mobilidade será obviamente motivado pela procura de matériasprimas essenciais (Sousa - Gonçalves 2012), reflectido na introdução de sílex estremenho na área alentejana (Andrade 2015b) e na introdução de rochas anfibólicas alentejanas na área estremenha (Cardoso - Carvalhosa 1995; Lillios 1997). No contexto destas movimentações, o curso do Tejo terá assim desempenhado papel fundamental na ligação destas duas regiões.

Esta circulação de gentes e materiais foram comprovadas com recentes análises isotópicas realizadas sobre restos humanos provenientes de contextos funerários estremenhos do Neolítico final e Calcolítico - sendo especialmente esclarecedores os resultados referentes a Cova da Moura e a Cabeço da Arruda 1, confirmando-se que pelo menos parte dos indivíduos aí inumados seria originalmente proveniente do Alentejo (Silva 2003; Waterman et al. 2013; Lillios et al. 2014; cf. igualmente Hillier et al. 2010). Estas relações estariam contudo já activas desde pelo menos o Neolítico médio, segundo os resultados obtidos com as análises isotópicas do Algar do Bom Santo (Carvalho 2014).

A extensão destas redes de intercâmbio é evidente, por exemplo, na presença de sílex oolítico de Granada no Alentejo e Extremadura espanhola (Nocete et al. 2005; Cerrillo Cuenca 2009; Morgado Rodríguez et al. 2011; Boaventura et al., no prelo), ou nas características específicas das placas de xisto gravadas com Olhos raiados «baculíformes» distribuídas desde Sevilha à Península de Lisboa (Andrade 2015a).

O que fica por definir com maior rigor é efectivamente a identidade dos agentes destes intercâmbios nos vários pólos deste vasto território, manifestando mecanismos complexos de interacção delineados por todo o Sudoeste peninsular, enquadrados nos processos de consolidação das sociedades camponesas estáveis do Neolítico final e Calcolítico.

Coruche/Montemor-o-Novo/Lisboa Verão/Outono de 2015

\section{REFERÊNCIAS BIBLIOGRÁFICAS}

ALMAGRO BASCH, M. (1961-62) - Un ajuar dolménico excepcional procedente de la Granja de Céspedes de Badajoz. Homenaje a C. Mergelina. Múrcia: 35-82.

ALMAGRO BASCH, M. - AMO DE LA HERA, M. -BELTRÁN MARTÍNEZ, A. - BLANCO FREIJEIRO, A. - CERDÁN MÁRQUEZ, C. - FERNÁNDEZ-MIRANDA FERNÁNDEZ, M. - GARRIDO ROIZ, J. P. - LEISNER, G. - LEISNER, V. LUZÓN NOGUÉ, J. M. - ORTA, E. M. (1975) - Huelva: Prehistoria y Antigüedad. Madrid.

ANDRADE, M. A. (2009) - Megalitismo e comunidades megalítica na área da Ribeira Grande (Alto Alentejo): definição e caracterização do fenómeno de «megalitização» da paisagem na área austral do Norte alentejano. Dissertação de Mestrado apresentada à Faculdade de Letras da Universidade de Lisboa. 2 vols., policopiado.

ANDRADE, M. A. (2013) - As placas de xisto gravadas da anta da Herdade da Lameira (Alto Alentejo, Portugal). O Arqueólogo Português 5 a série, 3: 177-201. ANDRADE, M. A. (2015a) - Cherchez la femme! Iconografia e imagética nas placas de xisto gravadas do Megalitismo do Sudoeste da Península Ibérica. In COLLADO GIRALDO, H. - GARCÍA ARRANZ, J. J. (eds.), Symbols in the Landscape: Rock Art and its Context. Proccedings of the XIXInternational Rock Art Conference IFRAO 2015 (Cáceres, Spain). Tomar (Arkeos, 37): 15451571.

ANDRADE, M. A. (2015b) - From matter to essence. Sourcing raw materials for the votive artefacts of the megalithic communities in Ribeira da Seda (Alto Alentejo, Portugall: a preliminary approach. Poster apresentado a MEGA-TALKS 2. Megaliths and Geology: Moving Stones in the Neolithic - MEGAGEO 2015, Redondo.

ANDRADE, M. A. - COSTEIRA, C. - MATALOTO, R. (2015) - Símbolos de morte em espaços de vida? Sobre a presença de placas de xisto gravadas em povoados do Alto Alentejo, no contexto do Sudoeste peninsular. In COLLADO GIRALDO, H. - GARCÍA ARRANZ, J. J. (eds.), Symbols in the Landscape: Rock Art and its Context. 
Proceedings of the XIXInternational RockArt Conference IFRAO 2015 (Cáceres, Spain). Tomar (Arkeos, 37): 16071635.

ANDRADE, M. A. - COSTEIRA, C. - MATALOTO, R. (2016) - Placas de xisto gravadas em contexto de povoado: o caso do Castelo de Pavia (Mora). Al-Madan - Adenda Electrónica 20-2: 43-53.

ANDRADE, M. A. - LOPES, G. - VILELA, C. (2014) - O sítio calcolítico de Cabeço dos Mouros: identificação de uma nova oficina de talhe de pontas de seta na área de Arruda dos Pisões (Rio Maior, Portugal). Revista Portuguesa de Arqueologia 17: 113-126.

ANDRADE, M. A. - MAURÍCIO, J. - SOUTO, P. (2010) Contributo para a definição das práticas funerárias neolíticas e calcolíticas no Maciço Calcário Estremenho. 1: Estudo morfo-tipológico de duas placas de xisto gravadas provenientes da gruta da Buraca da Moura da Rexaldia (Chancelaria, Torres Novas). Nova Augusta 2a série, 22: 239-259.

ANDRADE, M. A. - NEVES, C. - LOPES, G. (2015) - Beyond the Mesolithic shell middens: a chrono-cartographic overview of the ancient peasant communities in Muge. In BICHO, N.; DETRY, C.; PRICE, D.; CUNHA, E., (eds.), Muge 150th: The 150th Anniversary of the Discovery of the Mesolithic Shellmiddens. Cambridge: 2: 29-44.

ARNAUD, J. M. (1989) - Os concheiros mesolíticos dos vales do Tejo e do Sado: semelhanças e diferenças. In JORGE, V. O. (ed.), Livro de Homenagem a Jean Roche. Porto: 219-230.

ARNAUD, J. M. (2013) - Reflexões em torno das placas de cerâmica com gravuras de Vila Nova de S. Pedro (Azambuja). In ARNAUD, J. M. - MARTINS, A. - NEVES, C., (coords.), Arqueologia em Portugal: 150 anos. Lisboa: 447-455.

AUBRY, T. - MANGADO LLACH, J. - MATIAS, H. (2014) - Matérias-primas das ferramentas de pedra lascada da Pré-História do Centro e Nordeste de Portugal. In DINIS, P. - GOMES, A. - MONTEIRO-RODRIGUES, S. (eds.), Proveniências de Materiais Geológicos: abordagens sobre o Quaternário de Portugal. Braga: 165-192.

AZEVÊDO, M. T. M. (2004) - As mudanças de percurso do Tejo nos tempos modernos. Causas naturais e antrópicas. In TAVARES, A. A. - TAVARES, M. J. F. CARDOSO, J. L. (eds.), Evolução geo-histórica do litoral português e fenómenos correlativos. Lisboa: 517-567.

BAR-YOSEF, O. (1998) - The Natufian Culture in the Levant, Threshold to the Origins of Agriculture. Evolutionary Anthropology 6-5: 159-177.

BICHO, N. - CASCALHEIRA, J. - MARREIROS, J. - PEREIRA, T. (2011) - The 2008-2010 excavations of Cabeço da
Amoreira, Muge, Portugal. Mesolithic Miscellany 21-2: 3-13.

BICHO, N. - DIAS, R. - PEREIRA, T. - CASCALHEIRA, J. MARREIROS, J. - PEREIRA, V. - GONÇALVES, C. (2015) - O Mesolítico e o Neolítico antigo: o caso dos concheiros de Muge. In GONÇALVES, V. S. - DINIZ, M. - SOUSA, A. C. (eds.), $5^{\circ}$ Congresso do Neolítico Peninsular. Lisboa: 631-640.

BOAVENTURA, R. - MATALOTO, R. (2011) - O I milénio a.n.e. no concelho de Monforte: subsídios para o inventário do património arqueológico. Revista Portuguesa de Arqueologia 14: 107-140.

BOAVENTURA, R. - MATALOTO, R. - ANDRADE, M. A. NUKUSHINA, D. (no prelo) - Estremoz 7 ou a Anta de Nossa Senhora da Conceição dos Olivais (Estremoz, Évora). O Arqueólogo Português 5 a série, 4/5.

BUENO RAMÍREZ, P. (1988) - Los dólmenes de Valencia de Alcántara. Madrid (Excavaciones Arqueológicas en España, 155).

CALADO, M. (2001) - Da serra d'Ossa ao Guadiana: um estudo de pré-história regional. Lisboa (Trabalhos de Arqueologia, 19).

CARDOSO, J. L. (2016) - Báculos e placas de xisto: os primórdios da sua investigação. In SOUSA, A. C. CARVALHO, A. - VIEGAS, C. (eds.), Terra éfgua. Escolher sementes, invocar a Deusa. Estudos em homenagem a Victor S. Gonçalves. Lisboa: 69-79.

CARDOSO, J. L. - CARREIRA, J. R. (2003) - O povoado calcolítico do Outeiro de São Mamede (Bombarral): estudo do espólio das escavações de Bernardo de Sá (1903/1905). Estudos Arqueológicos de Oeiras 11: 97228.

CARDOSO, J. L. - CARVALHO, A. F. - GIBAJA BAO, J. F. (2013) - O sítio do Neolítico Antigo de Cortiçóis - Almeirim, Santarém. Revista Portuguesa de Arqueologia 16: 27-61.

CARDOSO, J. L. - CARVALHOSA, A. B. (1995) - Estudos petrográficos de artefactos de pedra polida do povoado pré-histórico de Leceia (Oeiras): análise de proveniências. Estudos Arqueológicos de Oeiras 5: 123151.

CARDOSO, J. L. - FERREIRA, O. V. - CARREIRA, J. R. (1996) - O espólio arqueológico das grutas naturais da Senhora da Luz (Rio Maior). Estudos Arqueológicos de Oeiras 6: 195-256.

CARREIRA, J. R. - CARDOSO, J. L. (2001-2002) - A gruta da Casa da Moura (Cesareda, Óbidos) e sua ocupação pós-paleolítica. Estudos Arqueológicos de Oeiras 10: 249-361.

CARTAILHAC, M. E. (1886) - Les âges préhistoriques d I'Espagne et du Portugal. Paris.

CARVALHO, A. F. (2014) - Bom Santo Cave (Lisbon) and 
the Middle Neolithic Societies os Southern Portugal. Faro (Promontoria Monográfica, 17).

CAUVIN, J. (1997) - Naissance des Divinités, Naissance d l'Agriculture. Paris.

CERDÁN MÁRQUEZ, C. - LEISNER, G. - LEISNER, V. (1952) - Los sepulcros megaliticos de Huelva. Excavaciones Arqueológicas del Plan Nacional 1946. Madrid (Informes y Memorias, 26).

CERRILLO CUENCA, E. (2009) - Laminas de sílex en el actual territorio de Extremadura (IV-III milenio cal $B C)$ : problemas de partida y posibilidades de estudio. In GIBAJA, J. F. - TERRADAS, X. - PALOMO, A. - CLOP, X. (eds.), Les grands fulles de sílex. Europa al final de la Prehistòria. Actes. Barcelona: 55-62.

CHRISTENSEN, M. - VALLA, F. (1999) - Pour relancer un débat: que sont les pierres à rainure du Natoufien Proche-Oriental? Bulletin de la Société Préhistorique Française 96: 247-252.

CORREIA, V. (1915) - Bibliografia: I. O Archeologo Português 20: 1-12, 298-300.

COSTA, F. A. P. (1868) - Descripção de alguns dolmins ou antas de Portugal. Lisboa.

DAVEAU, S. (1980) - Espaço e Tempo. Evolução do ambiente geográfico de Portugal ao longo dos tempos pré-históricos. Clio 2, 13-37.

DINIZ, M. (2007) - O sítio da Valada do Mato (Évora): aspectos da neolitização no Interior/Sul de Portugal. Lisboa (Trabalhos de Arqueologia, 48).

DINIZ, M. - VIEIRA, T. (2007) - Instrumentos de pedra polida e afeiçoada do povoado do Neolítico Antigo da Valada do Mato (Évora): estratégias de produção e modelos de uso. Vipasca 2a série, 2: 81-94.

DUBREUIL, L. (2004) - Long-term trends in Natufian subsistence: A use-wear analysis of ground stone tools. Journal of Archaeological Science 31: 1613-1629. FERREIRA, O. V. (1970) - Alguns objectos inéditos, bastante raros, da colecção do Prof. Manuel Heleno. O Arqueólogo Português 3a série, 4: 165-174.

FERREIRA, O.V.(1974) - Acerca das cerâmicas neolíticas encontradas na parte superior dos concheiros da região de Muge (Portugal). Comunicações dos Serviços Geológicos de Portugal 58: 191-195.

FORENBAHER, Stašo (1999) - Production and Exchange of Bifacial Flaked Stone Artifacts during the Portuguese Chalcolithic. Oxford (BAR International Series, 756).

FREITAS, M. C. - ANDRADE, C. - AZEVÊDO, T. M. PEREIRA, A. R. - RAMOS, C. - NUNES, E. - PEREIRA, D. I. (2006) - Understanding Lateglacial and Holocene Environmental changes trough the Sedimentological Study of a Core (Santarém Region). Tagus Floods '06 Workshop. Lisboa: 85-89.

FREITAS, M. C. - ANDRADE, C. - SILVA, T. - PINTO, C. -
AMORIM, A. (2013) - Evolução holocénica da Ponta da Passadeira (estuário do Tejo). In SOARES, J. (ed.), Pré-História das zonas húmidas. Paisagens de Sal (Setúbal Arqueológica, 14). Setúbal: 197-218.

GALLET, M. (1998) - Pour une technologie des débitages laminaires préhistorique. Paris (Dossier de Documentation Archéologique, 19).

GOMES, J. J. F. - BATISTA, J. (1991) - Sítios arqueológicos no Museu Municipal de Hipólito Cabaço (Alenquer): 1. Estações fora de Alenquer. Actas das IV Jornadas Arqueológicas. Lisboa: 367-379.

GONÇALVES, V. S. (1982) - O povoado calcolítico do Cabeço do Pé da Erra (Coruche). Clio 4: 7-18.

GONÇALVES, V. S. (1983-84a) - Cabeço do Pé da Erra (Coruche), contribuição da campanha 1 (83) para o conhecimento do seu povoamento calcolítico. Clio/ Arqueologia 1: 69-75.

GONÇALVES, V. S. (1983-84b) - Programa para o estudo da evolução das sociedades agro-pastoris, das origens à metalurgia plena, dos espaços abertos aos povoados fortificados, no centro de Portugal (ESAG). Clio/Arqueologia 1: 207-211.

GONÇALVES, V. S. (1987) - O povoado pré-histórico da Sala no 1 (Pedrógão, Vidigueira): notas sobre a campanha 1(88). Portugália Nova série, 8: 7-24.

GONÇALVES, V. S. (1989a) - Megalitismo e metalurgia no Alto Algarve Oriental: uma aproximação integrada. Lisboa.

GONÇALVES, V. S. (1989b) - Manifestações do sagrado na Pré-História do Ocidente peninsular. 1: Deusa(s) Mãe, placas de xisto e cronologias: uma nota preambular. Almansor 7: 289-302.

GONÇALVES, V. S. (1999) - Reguengos de Monsaraz, territórios megalíticos. Lisboa.

GONÇALVES, V. S. (2003) - STAM-3, a anta 3 da Herdade de Santa Margarida (Reguengos de Monsaraz). Lisboa: Instituto Português de Arqueologia (Trabalhos de Arqueologia, 32).

GONÇALVES, V. S. (2004) - As placas de xisto gravadas dos sepulcros colectivos de Aljezur (3० milénio a.n.e). O Arqueólogo Português 4a série, 22: 163-318.

GONÇALVES, V. S. (2009) - Um sítio do Neolítico antigo no Vale do Sorraia: Casas Novas (Coruche). Revista Portuguesa de Arqueologia 12-2: 5-30.

GONÇALVES, V. S. (2011) - As placas de xisto gravadas (e os báculos) do sítio do Monte da Barca (Coruche). Lisboa (Cadernos da UNIARQ, 7).

GONÇALVES; V. S. (2013) - No limite oriental do Grupo Megalítico de Reguengos de Monsaraz. Évora (Memórias d'Odiana, 2a série, 4).

GONÇALVES, V. S. - ANDRADE, M. A. - PEREIRA, A. (2005) - As placas de xisto gravadas e o báculo 


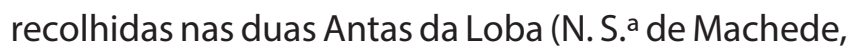
Évora). Revista Portuguesa de Arqueologia 8-2: 5-53. GONÇALVES, V.S. - ANDRADE, M. A. - PEREIRA, A. (2014) - As placas votivas (e o báculo) da gruta da Lapa da Galinha, no $3^{\circ}$ milénio a.n.e. Estudos Arqueológicos de Oeiras 21: 109-158.

GONÇALVES, V. S. - SOUSA, A. C. (2014) - Coruche e as antigas sociedades camponesas. In Coruche, o céu, a terra e os homens. Coruche: 29-67.

GONÇALVES, V. S. - SOUSA, A. C. (2015) - O sítio do Neolítico antigo de Casas Novas (Coruche). Leituras preliminares. In GONÇALVES, V. S. - DINIZ, M. - SOUSA, A. C. (eds.), $5^{\circ}$ Congresso do Neolítico Peninsular. Lisboa: 236-255 (Estudos \& Memórias, 8).

GONÇALVES, V. S. - SOUSA, A. C. - ANDRADE, M. A. (no prelo) - O Barranco do Farinheiro (Coruche) e a presença campaniforme na margem esquerda do baixo Tejo. In Sinos e Taças: junto ao Oceano e mais longe. Aspectos da presença campaniforme na Peninsula lbérica. Lisboa.

HARRISON, R. J. (1977) - The Bell Beaker Cultures of Spain and Portugal. Cambridge.

HILLIER, M. - BOAVENTURA, R. - GRIMES, V. (2010) Moving around? Testing mobility with strontium isotopes (86Sr/87Sr) in the Late Neolithic of SouthCentral Portugal. Poster apresentado ao $8^{\circ}$ Encontro de Arqueologia do Algarve: a Arqueologia e as outras Ciências. Silves.

HURTADO, V. (1980) - Los ídolos calcolíticos de La Pijotilla (Badajoz). Zephyrus 30-31: 165-203.

HURTADO, V. (1987) - El Calcolítico en la Cuenca Media del Guadiana y la necrópolis de la Pijotilla. In Actas de la Mesa Redonda sobre Megalitismo Peninsular. Madrid: 51-75.

ISIDORO, A. F. (1965-66) - Escavações em dólmenes do concelho do Crato (Alto Alentejo). Trabalhos de Antropologia e Etnologia 20 1-2: 29-57.

ISIDORO, A. F. (1970) - Escavações em dólmenes do concelho do Crato (Alto Alentejo): III. Trabalhos de Instituo de Antropologia Dr. Mendes Corrêa 6: 3-18.

ISIDORO, A. F. (1971) - Escavações em dólmenes do concelho do Crato (Alto Alentejo): IV. Trabalhos de Antropologia e Etnologia 22-1: 41-56.

KALB, P. - HÖCK, M. (1981-82) - Cabeço da Bruxa, Alpiarça (Distrito de Santarém). Relatório preliminar das escavações de Janeiro e Fevereiro de 1979. Portugália 2-3: 61-69.

KOERPER, H. C. - PETERSON, P. A. - VARGAS, B. R.; GRENDA, D. R. - STANTON, P. B. (2004) - Mortuary/ Mourning Associated, Transversely Grooved Stone Artifacts from CA-LAN-62: Another Case of Sexualization-Sacralization. Pacific Coast
Archaeological Society Quarterly 40-2: 51-79.

LAGO, M. - DUARTE, C. - VALERA, A. - ALBERGARIA, J. - ALMEIDA, F. - CARVALHO, A. F. (1998) - Povoado dos Perdigões (Reguengos de Monsaraz): dados preliminares dos trabalhos arqueológicos realizados em 1997. Revista Portuguesa de Arqueologia 1-1: 45152.

LEISNER, G. - LEISNER, V. (1959) - Die Megalithgräber der Iberischen Halbinsel: der Westen. 1: 2. Berlin.

LEISNER, V. (1965) - Die Megalithgräber der lberischen Halbinsel: der Westen. 1: 3. Berlin.

LILLIOS, K.(1997)-AmphiboliteToolsofthePortuguese Copper Age (3000-2000 B.C.): A Geoarchaeological Approach to Prehistoric Economics and Symbolism. Geoarchaeology 12-2: 137-163.

LILLIOS, K. - ARTZ, J. A. - WATERMAN, A. J. - MACK, J. - THOMAS, J. T. - TRINDADE, L. - LUNA, I. (2014) The rock-cult tomb of Bolores (Torres Vedras): an interdisciplinary approach to understanding the social landscape of the Neolithic/Copper Age of the Iberian Peninsula. Trabajos de Prehistoria 71-2: 282304.

LOPES, [E. A.] Correia (1913) - Aquisições do Museu Etnológico Português: I. O Archeólogo Português 187-12: 131-165.

LÓPEZ DE PABLO, J. F. - GARCÍA PUCHOL, O. - JUANCABANILLES, J. (2006) - Les lames de silex de grand format du Néolitique final et de l'Énéolithique du Pays Valencien (Espagne). Aspects technologiques d'une production singulière. In VAQUER, J. - BRIOIS, F. (dir.), La fin d'âge de Pierre en Europe du Sud. Actes de la Table Ronde d I'EHESS. Toulouse: 257-271.

MARTINS, A. (2004) - As bacias sedimentares do Baixo Tejo e Sado. In FEIO, M. - DAVEAU, S. (eds.), O relevo de Portugal. Grandes unidades regionais. Coimbra: 49-60. MATIAS, H. (2012) - O aprovisionamento de matériasprimas líticas na gruta da Oliveira (Torres Novas). Dissertação de Mestrado em Geo-Arqueologia apresentada à Faculdade de Ciências da Universidade de Lisboa, policopiado.

MEJÍAS-GARCÍA, J. C. - CRUZ-AUÑÓN BRIONES, M. R. - PAJUELO PANDO, A. - LÓPEZ ALDANA, P. M. (2015) - Análisis del modelo de organización espacial de la necrópolis de Valencina. La complejidad social a debate. In BRANCO, G. - ROCHA, L. - DUARTE, C. OLIVEIRA, J. - BUENO RAMÍREZ, P. (eds.), Arqueologia de Transição: o mundo funerário. Actas do II Congresso Internacional de Arqueologia de Transição. Évora: 5270.

MORÁN, E. - PARREIRA, R. (2007) - Alcalar. Monumentos megalíticos. Lisboa.

MORGADO RODRÍGUEZ, A. - LOZANO RODRÍGUEZ, J. 
A. - PELEGRIN, J. (2011) - Las explotaciones del sílex de la formácion Milanos (Granada, España). Menga 2: 135-155.

MORGADO, A. - PELEGRIN, J. (2012) - Origin and development of pressure blade production in the Southern Iberian Peninsula (6th-3rd millennia B.C.). In DESROSIERS, P. (ed.), The Emergence of Pressure Blade Making. From Origins to Modern Experimentation. New York: 219-235.

MORGADO RODRÍGUEZ, A. - PELEGRIN, J. - AUBRY, T. - LOZANO RODRÍGUEZ, J. A. (2009) - La producción especializada de grandes láminas del Sur y Oeste de la Península Ibérica. In GIBAJA, J. F. - TERRADAS, X. PALOMO, A. - CLOP, X. (eds.), Les grands fulles de sílex. Europa al final de la Prehistòria. Actes. Barcelona: 8997.

NEVES, C. (2010) - Monte da Foz 1 (Benavente): um episódio da Neolitização na margem esquerda do Baixo Tejo. Dissertação de Mestrado em Arqueologia apresentada à Faculdade de Letras da Universidade de Lisboa. Policopiado.

NEVES, C. - DINIZ, M. - LOPES, G. (2015) - Casas Velhas do Coelheiro (Salvaterra de Magos, Portugal): notícia da sua identificação. Revista Portuguesa de Arqueologia 18: 27-40.

NEVES, C. - RODRIGUES, F. - DINIZ, M. (2008) Neolithization process in lower Tagus valley left bank: old perspectives and new data. In DINIZ, M. (ed.), Early Neolithic in the Iberian Peninsula: Regional and Transregional Components. Oxford: 43-51.

NOCETE CALVO, F. (2004) - Odiel: proyecto de investigación arqueológica para el analisis del origen de la desigualdad social en el suroeste de la Peninsula Iberica. Sevilla (Arqueologia, Monografias 19).

NOCETE, F. - SÁEZ, R. - NIETO, J. M. - CRUZ-AUÑÓN, R. - CABRERO, R. - ALEX, E. - BAYONA, M. R. (2005) Circulation of silicified oolitic limestone blades in South-Iberia (Spain and Portugal) during the third millennium B.C.: na expression of a core/periphery framework. Journal of Anthropological Archaeology 24: 62-81.

OLIVEIRA, C. D. - OLIVEIRA, J. (2000) - Continuidade e rupturas do megalitismo no distrito de Portalegre. In JORGE, V. O. (coord.), Actas do $3^{\circ}$ Congresso de Arqueologia Peninsular. Porto: 459-471 (ADECAP. 3 Neolitização e Megalitismo da Península lbérica).

PARREIRA, R. (1987) - Calcolítico do Vale do Tejo. In SILVA, A. C. (coord.), Arqueologia no Vale do Tejo. Lisboa: 44-47.

PEREIRA, J. M. (2005) - Riba-Rio: um povoado calcolítico da bacia do médio Tejo. Al-madan adenda electrónica $2^{\mathrm{a}}$ série, 13: III.1-III.7.
PIMENTA, J. - HENRIQUES, E. - MENDES, H. (2012) - O acampamento romano do Alto dos Cacos, Almeirim. Almeirim.

PIMENTA, J. - MENDES, H. - ARRUDA, A. M. - SOUSA, E. - SOARES, R. (2014) - Do pré-romano ao Império: a ocupação romana do Porto de Sabugueiro (Muge, Salvaterra de Magos). Magos 1: 39-57.

PLISSON, H. - DUBREUIL, L. - GUILBERT, R. (2008) - The functional significance of Sauveterrian microlithic assemblages: broadening the focus of investigation. In LONGO, L. - SKAKUN, N. (eds.), "Prehistoric technology" 40 years later: functional studies and the Russian legacy. Oxford: 147-156 (BAR International Series, 1783).

PONTIS (1999) - Carta Arqueológica de Ponte de Sor. Ponte de Sor.

RIBEIRO, C. (1878) - Estudos Prehistoricos em Portugal. Noticia de algumas estações e monumentos prehistoricos. II - Monumentos megalithicos das visinhanças de Bellas. Lisboa.

RIEDE, F. (2012) - A possible Brommian shaftsmoother from the site of Møllehøje, north-western Denmark. Mesolithic Miscellany 22-1: 10-18.

ROCHA, L. (1999) - Povoamento Megalítico de Pavia. Contributo para o conhecimento da Pré-história regional. Mora.

SANTOS, C. T. N. (2010) - Reconstrução das condições paleoambientais e paleoclimáticas no estuário do Tejo durante o Holocénico ( $\approx 12000$ anos). Dissertação de Mestrado em Ciências do Mar/Recursos Marinhos apresentada ao Instituto de Ciências Biomédicas Abel Salazar da Universidade do Porto. Policopiado.

SILVA, A. M. (2003) - Portuguese populations of Late Neolithic and Chalcolithic periods exhumed from collective burials: an overview. Anthropologie 41, 1-2: 55-64.

SIMÕES, A. F. (1878) - Introdução à Archeologia da Península lbérica. Lisboa.

SOARES, J. (2013) - Sal e conchas na Pré-História portuguesa. O povoado da Ponta da Passadeira (estuário do Tejo). In SOARES, J. (ed.), Pré-História das Zonas Húmidas. Paisagens de Sal. Setúbal: 171-196 (Setúbal Arqueológica, 14).

SOARES, A. M. M.; REAL, F. (2005) - Um ídolo calcolítico em pedra encontrado na Serra da Preguiça (Sobral da Adiça, Moura). Revista Portuguesa de Arqueologia. Lisboa, 8: 2, 107-113.

SOUSA, A. C. (2004) - A necrópole do Neolítico final de Pragais, Porto de Mós: velhos dados, novas leituras. In Arqueologia: colecções de Francisco Tavares Proença Júnior. Castelo Branco: 90-111.

SOUSA, A. C. (2010) - O Penedo do Lexim e a sequência 
do Neolítico Final e Calcolítico da Península de Lisboa. Dissertação de Doutoramento apresentada à Faculdade de Letras da Universidade de Lisboa. 2 vols., policopiado.

SOUSA, A. C. - GONÇALVES, V. S. (2012) - In and out. Tecnologias, símbolos e cultura material. Interacções e identidades regionais no Centro e Sul de Portugal no $3^{\circ}$ milénio a.n.e. In BORRELL, M. - BORRELL, F. - BOSCH, J. - CLOP, X. - MOLIST, M. (eds.), Xarxes al Neolític. Circulació $i$ intercanví de matèries, productes $i$ idees a la Mediterrània occidental (VII-III mil lenni aC). Gavá: 383-392 (Rubricatum, extra 5).

SPINDLER, K. (1981) - Cova da Moura. Mainz am Rhein. VALERA, A. C. (2010) - Gestão da Morte no $3^{\circ}$ milénio AC no Porto Torrão (Ferreira do Alentejo): um primeiro contributo para a sua espacialidade. Apontamentos de Arqueologia e Património 5: 57-62.

VALERA, A. C. - TERESO, J. - REBUGE, J. (2007) - O Monte da Quinta 2 (Benavente) e a produção de sal no Neolítico Final/Calcolítico do estuário do Tejo. In BICHO, N. - VERÍSSIMO, H. (eds.), Do Epipaleolítico ao Calcolítico na Península Ibérica. Actas do IV Congresso de Arqueologia Peninsular. Faro: 291-305 (Promontoria Monográfica, 4).

VALERA, A. C. - LAGO, M. - DUARTE, C. - DIAS, I. PRUDÊNCIO, I. (2007) - Investigações no Complexo Arqueológico dos Perdigões: ponto da situação de dados e problemas. In JORGE, S. O. - BETTENCOURT, A. M. S.; FIGUEIRAL, I. (eds.), A concepção das paisagens e dos espaços na Arqueologia da Península lbérica. Actas do IV Congresso de Arqueologia Peninsular. Faro: 53-66 (Promontoria Monográfica, 8).

VALERA, A. C. - LAGO, M. - DUARTE, C. - EVANGELISTA, L. S. (2000) - Ambientes funerários no Complexo Arqueológico dos Perdigões. Era-Arqueologia 2: 2861.

VALERA, A. C. - SANTOS, H. - FIGUEIREDO, M. - GRANJA, R. (2014) - Contextos funerários na periferia do Porto Torrão: Cardim 6 e Carrascal 2. In $4^{\circ}$ Encontro de Arqueologia do Alqueva. O Plano de Rega (2002-2010). Évora: 83-95 (Memórias d'Odiana, 2a série, 14). VAN DER SCHRIEK, T. - PASSMORE, D. G. - FRANCO MUGIBA, F. - STEVENSON, A. C. - BOOMER, I. - ROLÃO, J. (2008) - Holocene palaeoecology and floodplain evolution of the Muge tributary, Lower Tagus Basin, Portugal. Quaternary International 189: 135-151.

VAN DER SCHRIEK, T. - PASSMORE, D. G. - ROLÃO, J. STEVENSON, A. C. (2007) - Estuarine-fluvial floodplain formation in the Holocene Lower Tagus valley (Central Portugal) and implications for Quaternary fluvial system evolution. Quaternary Science Reviews 26: 2937-2957.

VARANDA, A. - ANDRADE, M. A. (no prelo) - O Paleolítico Inferior no sítio do Sobral do Martim Afonso (Muge, Salvaterra de Magos): a colecção do Museu Nacional de Arqueologia. Revista Portuguesa de Arqueologia 20.

VEIGA, S. P. M. E. (1887) - Paleoethnologia. Antiguidades Monumentaes do Algarve. Tempos prehistoricos, 2. Lisboa.

VEIGA, S. P. M. E. (1889) - Paleoethnologia. Antiguidades Monumentaes do Algarve. Tempos prehistoricos, 3. Lisboa.

VICENTE, E. P. - ANDRADE, G. E. M. - DIAS, V. M. R. (1971) - Uma jazida pré-histórica no Vale do Sorraia. Actas do III Congresso Nacional de Arqueologia. Porto, 1:91-104.

VIS, G.-J. - BOHNCKE, S. J. P. - SCHNEIDER, H. - KASSE, C. - COENRAADS-NEDERVEEN, S. - ZUURBIER, K. ROZEMA, J. (2010) - Holocene flooding history of the Lower Tagus Valley (Portugal). Journal of Quaternary Science 25-8: 1222-1238.

VIS, G.-J. - KASSE, C. - VANDENBERGHE, J. (2008) Late Pleistocene and Holocene paleogrography of the Lower Tagus Valley (Portugal): effects of relative sea level, valley morphology and sediment supply. Quaternary Science Reviews 27: 1682-1709.

WATERMAN, A. J. - PEATE, D. W. - SILVA, A. M. - THOMAS, J. T. (2013) - In search of homelands: using strontium isotopes to identify biological markers of mobility in late prehistoric Portugal. Journal of Archaeological Science 42: 119-127.

ZILHÃO, J. (1994) - A oficina de talhe neo-calcolítica de Casas de Baixo (Caxarias, Vila Nova de Ourém). Trabalhos de Arqueologia da EAM 2: 35-45.

ZILHÃO, J. (1997) - O Paleolítico Superior na Estremadura portuguesa. Lisboa. 


\section{OPHIUSSA}

\section{POLÍTICA EDITORIAL}

A Ophiussa - Revista do Centro de Arqueologia da Universidade de Lisboa foi iniciada sob a direcção de Victor S. Gonçalves em 1996, tendo sido editado o volume 0. O volume 1 (2017) é uma edição impressa e digital da UNIARQ - Centro de Arqueologia da Universidade de Lisboa.

O principal objectivo desta revista é a publicação e divulgação de trabalhos com manifesto interesse, qualidade e rigor científico sobre temas de Pré-História e Arqueologia, sobretudo do território europeu e da bacia do Mediterrâneo.

A Ophiussa - Revista do Centro de Arqueologia da Universidade de Lisboa publicará um volume anual. A partir de 2018, os artigos submetidos serão sujeitos a um processo de avaliação por parte de revisores externos (peer review). O período de submissão de trabalhos decorrerá sempre no primeiro trimestre e a edição ocorrerá no último trimestre de cada ano.

A revista divide-se em duas secções: artigos científicos e recensões bibliográficas. Excepcionalmente poderão ser aceites textos de carácter introdutório, no âmbito de homenagens ou divulgações específicas, que não serão submetidos à avaliação por pares. Isentas desta avaliação estão também as recensões bibliográficas.

Todas as submissões serão avaliadas, em primeira instância, pela Coordenação Editorial, no que respeita ao seu conteúdo formal e à sua adequação face à política editorial e às normas de edição da revista. Os trabalhos que cumprirem estes requisitos serão posteriormente submetidos a um processo de avaliação por pares cega / blind peer review (mínimo de dois revisores). O Conselho Científico, constituído pela direcção da UNIARQ e por investigadores externos, seleccionará os revisores e acompanhará o processo de edição.

Esta etapa será concretizada por investigadores externos qualificados, sendo os respectivos pareceres entregues num período não superior a três meses. Os revisores procederão à avaliação de forma objectiva, tendo em vista a qualidade do conteúdo da revista; as suas críticas, sugestões e comentários serão, na medida do possível, construtivos, respeitando as capacidades intelectuais do(s) autor(es). Após a recepção dos pareceres, o(s) autor(es) tem um prazo máximo de um mês para proceder às alterações oportunas e reenviar o trabalho.

A aceitação ou recusa de artigos terá como únicos factores de ponderação a sua originalidade e qualidade científica. $\mathrm{O}$ processo de revisão é confidencial, estando assegurado o anonimato dos avaliadores e dos autores dos trabalhos, neste último caso até à data da sua publicação.

Os trabalhos só serão aceites para publicação a partir do momento em que se conclua o processo da revisão por pares. Os textos que não forem aceites serão devolvidos aos seus autores.

O conteúdo dos trabalhos é da inteira responsabilidade do(s) autor(es) e não expressa a posição ou opinião do Conselho Científico ou da Coordenação Editorial.

As ilustrações que não sejam do(s) autor(es) devem indicar a sua procedência. O Conselho Científico e a Coordenação Editorial assumem que os autores solicitaram e receberam autorização para a reprodução dessas ilustrações, e, como tal, rejeitam a responsabilidade do uso não autorizado das ilustrações e das consequências legais por infracção de direitos de propriedade intelectual.

A publicação de textos na Ophiussa - Revista do Centro de Arqueologia da Universidade de Lisboa não implica o pagamento de qualquer taxa nem dá direito a qualquer remuneração económica.

Os textos propostos para publicação devem ser inéditos e não deverão ter sido submetidos a qualquer outra revista ou edição electrónica. Aceitam-se trabalhos redigidos em português, inglês, espanhol, italiano e francês.

Esta edição disponibiliza de imediato e gratuitamente a totalidade dos seus conteúdos, em acesso aberto, de forma a promover, globalmente, a circulação e intercâmbio dos resultados da investigação científica e do conhecimento.

Esta publicação dispõe de uma versão impressa, a preto e branco, com uma tiragem limitada, que será distribuída gratuitamente pelas bibliotecas e instituições mais relevantes internacionalmente, e intercambiada com publicações periódicas da mesma especialidade, que serão integradas na Biblioteca da Faculdade de Letras da Universidade de Lisboa. Conta, paralelamente, com uma versão digital, a cores, disponibilizada no endereço www.ophiussa.letras.ulisboa.pt, onde se pode consultar a totalidade da edição.

Para mais informações contactar: uniarq@letras.ulisboa.pt 


\section{OPHIUSSA}

\section{EDITORIAL POLICY}

Ophiussa - Revista do Centro de Arqueologia da Universidade de Lisboa started under the direction of Victor S. Gonçalves in 1996, with the edition of volume 0. Volume 1 (2017) is a printed and digital edition of UNIARQ - Centro de Arqueologia da Universidade de Lisboa.

The main objective of this journal is the publication and dissemination of papers of interest, quality and scientific rigor concerning Prehistory and Archeology, mostly from Europe and the Mediterranean basin.

Ophiussa - Revista do Centro de Arqueologia da Universidade de Lisboa will publish an annual volume. From 2018, submitted articles will be subject to a peer-review evaluation process. The submission period will always occur in the first quarter of each year and the edition will occur in the last quarter.

The journal is divided into two sections: scientific articles and bibliographic reviews. Exceptionally, texts of an introductory nature may be accepted, in the context of specific tributes or divulgations, which will not be submitted to peerreview evaluation. Exemptions from this evaluation are also the bibliographic reviews.

All submissions will be considered, in the first instance, by the Editorial Board, regarding its formal content and adequacy in face of the editorial policy and the journal's editing standards. Papers that meet these requirements will subsequently be submitted to a blind peer-review process (minimum of two reviewers). The Scientific Council, constituted by the directors of UNIARQ and external researchers, will select the peer-reviewers and follow the editing process.

This stage will be carried out by qualified external researchers, and their feedback will be delivered within a period of no more than two months. The reviewers will carry out the evaluation in an objective manner, in view of the quality and content of the journal; their criticisms, suggestions and comments will be, as far as possible, constructive, respecting the intellectual abilities of the author (s). After receiving the feedback, the author(s) has a maximum period of one month to make the necessary changes and resubmit the work.

Acceptance or refusal of articles will have as sole factors of consideration their originality and scientific quality. The review process is confidential, with the anonymity of the evaluators and authors of the works being ensured, in the latter case up to the date of its publication.

Papers will only be accepted for publication as soon as the peer review process is completed. Texts that are not accepted will be returned to their authors.

The content of the works is entirely the responsibility of the author(s) and does not express the position or opinion of the Scientific Council or Editorial Board.

Illustrations that are not from the author(s) must indicate their origin. The Scientific Council and Editorial Board assume that the authors have requested and received permission to reproduce these illustrations and, as such, reject the responsibility for the unauthorized use of the illustrations and legal consequences for infringement of intellectual property rights.

The publication of texts in Ophiussa - Revista do Centro de Arqueologia da Universidade de Lisboa does not imply the payment of any fee nor does it entitle to any economic remuneration.

Texts proposed for publication must be unpublished and should not have been submitted to any other journal or electronic edition. Works written in Portuguese, English, Spanish, Italian and French are accepted.

This edition immediately and freely provides all of its content, in open access, in order to promote global circulation and exchange of scientific research and knowledge.

This publication has a limited printed edition in black and white, which will be distributed free of charge by the most relevant international libraries and institutions, and exchanged with periodicals of the same specialty, which will be integrated in the Library of Faculdade de Letras of Universidade de Lisboa. It also has a digital version, in color, available at address www. ophiussa.letras.ulisboa.pt, where one can consult the entire edition.

For more information contact: uniarq@letras.ulisboa.pt 


\section{OPHIUSSA}

REVISTA DO CENTRO DE ARQUEOLOGIA DA UNIVERSIDADE DE LISBOA

\section{1 - 2017}

\section{ÍNDICE}

VICTOR S. GONÇALVES - Ophiussa regressa, em digital e, logo de seguida, em papel .... MARCO ANTÓNIO ANDRADE - O sítio pré-histórico do Sobral do Martim Afonso (Sätuatterra de Magos, Portugal): um curioso contexto do Neolítico Final / Calcolítico na marégentesquerda do Baixo Tejo

ANA CATARINA SOUSA - JORGE LOPES - O sítio do Moinho do Custódio (tarruda dos vinthost.

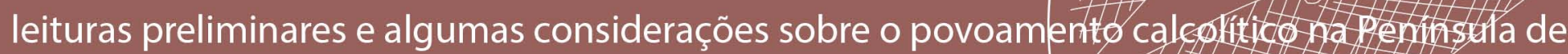
Lisboa

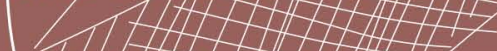
51

PEDRO ALBUQUERQUE - O Guadiana como fronteira? Notas para un profecto-de investigação

ANA MARGARIDA ARRUDA - ELISA DE SOUSA - JOÃO PIMENTA - RUI SOARES - HENRIQU MENDES - Fenícios e indígenas em contacto no Estuário do Tejo

ELISA DE SOUSA - Algumas reflexões sobre a fase tardia da Idade do Ferro no Ocidente Atlântico

CARLOS PEREIRA - Produção e comércio de lucernas durante a Antiguidade Tardia: génese e evolução das lucernas tardo-antigas de produção africana

JACINTA BUGALHÃO - O papel da mulher na Arqueologia Portuguesa

RUI BOAVENTURA - VERA.LEISNER@PORTUGAL.PT

RECENSÕES BIBLIOGRÁFICAS - Estudos Arqueológicos de Oeiras, 22 volumes e a contar... (VICTOR S. GONÇALVES) 